UNIVERSIDADE DE SÃO PAULO

ESCOLA DE ENFERMAGEM

MAIARA RODRIGUES DOS SANTOS

A RELAÇÃO DE AJUDA E CONFIANÇA ENTRE ENFERMEIROS E FAMILIARES DE CRIANÇAS INTERNADAS

SÃO PAULO

2012 
MAIARA RODRIGUES DOS SANTOS

\section{A RELAÇÃO DE AJUDA E CONFIANÇA ENTRE ENFERMEIROS E FAMILIARES DE CRIANÇAS INTERNADAS}

Dissertação apresentada ao Programa de Pós-Graduação em Enfermagem da Escola de Enfermagem da Universidade de São Paulo, para a obtenção do título de Mestre em Cuidado em Saúde.

Área de Concentração: Cuidado em Saúde

Orientadora: Prof. ${ }^{a}$ Dr. ${ }^{\stackrel{a}{ }}$ Regina Szylit Bousso

\section{SÃO PAULO}

2012 


\begin{abstract}
AUTORIZO A REPRODUÇÃO E DIVULGAÇÃO TOTAL OU PARCIAL DESTE TRABALHO, POR QUALQUER MEIO CONVENCIONAL OU ELETRÔNICO, PARA FINS DE ESTUDO E PESQUISA, DESDE QUE CITADA A FONTE.
\end{abstract}

Assinatura:

Data:

CATALOGAÇÃO NA PUBLICAÇÃO (CIP)

BIBLIOTECA "WANDA DE AGUIAR HORTA"

ESCOLA DE ENFERMAGEM DA UNIVERSIDADE DE SÃO PAULO

Santos, Maiara Rodrigues dos

A relação de ajuda e confiança entre enfermeiros e familiares de crianças internadas / Maiara Rodrigues dos Santos. -- São Paulo, 2012.

$118 \mathrm{f}$. .

Dissertação (Mestrado) - Escola de Enfermagem da Universidade de São Paulo.

Orientadora: Prof ${ }^{\underline{a}} \mathrm{Dr}^{\mathrm{a}}$ Regina Szylit Bousso

Área de concentração: Cuidado em Saúde

1. Família 2. Enfermagem - Teoria 3. Enfermagem pediátrica 4. Cuidados de enfermagem I. Título. 
Nome: Maiara Rodrigues dos Santos

Título: A relação de ajuda e confiança entre enfermeiros e familiares de crianças internadas

Dissertação apresentada ao Programa de Pós-Graduação em Enfermagem da Escola de Enfermagem da Universidade de São Paulo, para a obtenção do título de Mestre em Cuidado em Saúde.

Aprovado em

\section{Banca Examinadora}

Prof. Dr. Instituição:

Julgamento:

Assinatura:

Prof. Dr. Instituição:

Julgamento: Assinatura:

Prof. Dr. Instituição: Julgamento: Assinatura: 


\section{Agradecimento especial}

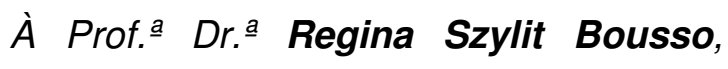
quem conduziu e ajudou na compreensão de cada passo dessa trajetória. É um prazer ter tão valiosa contribuição neste trabalho. Agradeço pela confiança em mim depositada, desde que nos conhecemos, ainda na graduação.

Agradeço de forma muito especial pelos ricos momentos que passamos e pela orientação, ao mesmo tempo competente, sincera e carinhosa. Sou grata, enfim, pelo CUIDADO cujo significado, para mim, envolve os saberes e as experiências possibilitados pelos seus ensinamentos. 


\section{Agradecimentos}

Agradeço à minha família, eterna fonte de força e amor. Por compreender as dificuldades e apoiar, incondicionalmente, a dedicação e o esforço necessários aos estudos. Serei eternamente grata a cada um de vocês pela maneira que me fazem entender a importância da 'família'; é inevitável reconhecê-los nos valores e aprendizados mais importantes da minha vida. Especialmente, agradeço àqueles que precisei envolver diretamente para conseguir concretizar este trabalho: aos meus pais, ao meu irmão, ao Vinícius, à minha tia Regina, meus primos Letícia, Glaucia e Eduardo.

Aos queridos amigos, por ouvirem minhas preocupações e se inquietarem com elas, pela torcida, e por estarem sempre ao meu lado, apoiando-me em cada escolha que faço.

Novamente, à minha orientadora, Profa. Dra. Regina Szyli Bousso, por ser minha referência e ter, com muita paciência, me ensinado como pensar e procurar as respostas para minhas perguntas.

À FAPESP - Fundação de Amparo à Pesquisa do Estado de São Paulo pela concessão da bolsa de mestrado.

À Prof. ${ }^{a}$ Dr. ${ }^{a}$ Roselena Bazilli Bergamasco, pelas contribuições e pelo apoio no exame de qualificação. Também, pela ajuda com as traduções dos materiais.

À Prof. ${ }^{a}$ Dr. ${ }^{\stackrel{a}{ }}$ Regina Aparecida Garcia de Lima, pelas sugestões propostas no exame de qualificação.

Aos enfermeiros que participaram deste estudo, pela atenção dispensada e tão importantes contribuições.

À enf. ${ }^{a}$ Patrícia Vendramim, pelo auxílio que tornou possível a condução deste estudo.

À querida Prof. ${ }^{a}$ Dr. ${ }^{a}$ Lisabelle Mariano Rossato, pelo acolhimento, pelos 'socorros' prestados a mim, pela ajuda com as traduções e por tornar mais leve a caminhada. À também, Prof. ${ }^{a}$ Dr. ${ }^{a}$ Elaine Buchhorn Cintra Damião, pela preocupação, disponibilidade e pelo auxílio com as traduções.

Aos membros do grupo de pesquisa NIPPEL, pelos momentos que compartilhamos e aprendemos juntos, por trazerem valiosas influências para a 
construção deste estudo. Especialmente, agradeço à Maira, pela amizade, pelos ensinamentos e paciência, desde os estágios e a iniciação científica. À Lucía, pelos momentos descontraídos e pela IMENSA disposição em ajudar. À Ana Marcia (Naná), pela brilhante e sempre bem humorada contribuição com este trabalho.

À Prof. ${ }^{a}$ Dr. ${ }^{a}$ Dulce Maria Rosa Gualda, pelas sugestões que contribuíram para este estudo. Também, ao Hudson, por sempre compartilhar seus aprendizados e pelas ajudas ao longo desse processo.

À Prof. ${ }^{a}$ Dr. ${ }^{a}$ Ana Maria Calil Sallum, pelas sempre acolhedoras palavras e pela ótima oportunidade de aprendizado que me concedeu.

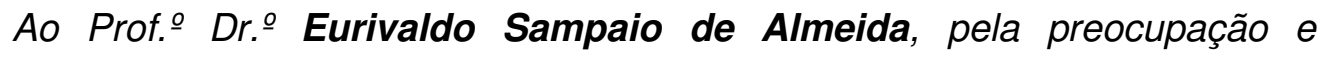
disponibilidade em ajudar, também pela oportunidade de crescimento e aprendizado no comum interesse de tornar o atendimento de saúde mais humano.

À Eliara Pilecco Machado, pela amizade e conversas descontraídas. Por confiar em mim quando ainda pouco nos conhecíamos e contribuir de forma tão especial para este trabalho.

Aos funcionários do departamento ENP, da secretaria de pós-graduação e da biblioteca, pela disposição em ajudar, pelo carinho e bom humor. 


\section{RESUMO}

Santos MR. A relação de ajuda e confiança entre enfermeiros e familiares de crianças internadas. [dissertação]. São Paulo: Universidade de São Paulo, Escola de Enfermagem, 2012. $118 \mathrm{f}$.

Os enfermeiros têm se mostrado mais conscientes da necessidade e do compromisso no estabelecimento do cuidado centrado na criança e na família. Entretanto, reconhecem dificuldades para o engajamento inicial com os familiares presentes no hospital, prejudicando a implementação dessa prática. Acreditamos que estratégias para esse engajamento devam incluir a criação de um contexto para que enfermeiras e famílias possam estabelecer uma relação de reciprocidade na qual a confiança, a comunicação regular, a transparência e a cooperação para atender as necessidades da família, sejam asseguradas. A Teoria do Cuidado Humano de Jean Watson permite ao enfermeiro desenvolver um relacionamento de ajuda e confiança com as famílias de crianças no contexto do cuidado. Este estudo teve como objetivo compreender a experiência dos enfermeiros sobre o desenvolvimento da relação de ajuda e confiança com famílias de crianças em unidades de pediatria, à luz da Teoria do Cuidado Humano de Jean Watson. Para tanto, adotou-se a abordagem qualitativa descritiva, utilizando o modelo híbrido de análise temática como referencial metodológico e a Teoria do Cuidado Humano como arcabouço teórico. A coleta de dados ocorreu em três etapas: apresentação de conteúdo teórico e material de apoio; vivência do relacionamento de ajuda e confiança; entrevista semi estruturada, realizada com doze enfermeiras de um hospital particular na cidade de São Paulo. Os resultados apontam para fatores internos e externos aos enfermeiros, relacionados com os dez caritas processes da teoria de Watson, que influenciam no estabelecimento da relação de ajuda e confiança no cuidado de famílias de crianças internadas, bem como os benefícios que essa teoria agrega na prática desses profissionais. A partir da compreensão dos enfermeiros sobre esse relacionamento, vimos que o referencial de Jean Watson pode ajudá-los a aproximarem-se da família de forma autêntica, consciente e intencional. Assim, a prática da relação de ajuda e confiança contribui para um melhor gerenciamento do cuidado ao reconhecerem o potencial que esse encontro tem para beneficiar as famílias de crianças no enfrentamento de uma situação de doença.

Palavras-chave: Família. Enfermagem - Teoria. Enfermagem pediátrica. Cuidados de enfermagem. 


\begin{abstract}
Santos MR. The Helping-Trusting Caring Relationship between nurses and families of hospitalized children. [dissertation]. São Paulo: Universidade de São Paulo, Escola de Enfermagem, 2012. 119 f.

Nurses have been more aware of the need and commitment in establishing a centred care on the child and their family. However, they recognize difficulties in an initial engagement with the family present at the hospital, hindering the implementation of such practice with them. We believe that strategies to promote this engagement should include the creation of a context which enables nurses and families to establish a reciprocal relationship in which trust, regular communication, honesty, as well as cooperation to attend the families' needs, can be guaranteed. Jean Watson's Human Caring Theory allows nurses to develop a helping-trusting caring relationship with children and families within the caring context. This study aimed to understand nurses' experience about the development of the helping-trusting caring relationship with families of children in pediatric units, in the light of Jean Watson's Human Caring Theory. We adopted the descriptive qualitative approach, using the hybrid model of thematic analysis as methodological framework and the Human Caring Theory as a theoretical framework. Data collection occurred in three stages: presentation of theoretical content and support material; experience in helping-trusting relationship; semi-structured interviews, with twelve nurses, from a private hospital in São Paulo. The results pointed to nurse's intrinsic and environmental factors, related with the caritas process of Watson's theory, that influence not only the development of a helping-trusting caring relationship with the families of hospitalized children, but also the benefits that this theory brings to nursing practice. From the nurses' perspectives on this relationship, we noticed that this theory can help them willingly approach the families, with authenticity, knowledge and awareness. Hence, the helping-trusting caring relationship contributes to improve the families' welfare, when they recognize the benefic potential that this meeting has for the children's families in facing an illness situation.
\end{abstract}

Descriptors: Family. Nursing - theory. Pediatric nursing. Nursing care. 


\section{LISTA DE QUADROS}

Quadro 1 - Descrição dos carative factors (1979) e caritas processes (20022007). 28

Quadro 2 - Concepções de um enfermeiro caritas: Relacionamento transpessoal - Caritas Consciousness 33 Quadro 3 - Caracterização dos participantes segundo tempo de formado e de trabalho na instituição do estudo, pós-graduação, experiências anteriores e unidade em que trabalha. 


\section{SUMÁRIO}

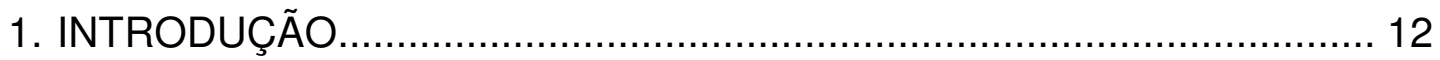

$1.1 \mathrm{O}$ cuidado no atendimento em saúde....................................... 14

$1.2 \bigcirc$ cuidado e a enfermagem ................................................... 16

1.3 A enfermagem e o cuidado centrado na criança e na família............. 18

1.4 A Teoria do Cuidado Humano de Jean Watson ............................. 24

1.4.1 Relacionamento de ajuda e confiança no cuidado: caritas

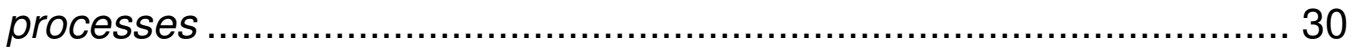

1.4.1.1 Relacionamento de cuidado transpessoal........................ 32

1.4.1.2 Momento de cuidado..................................................... 33

1.4.1.3 Congruência ........................................................ 34

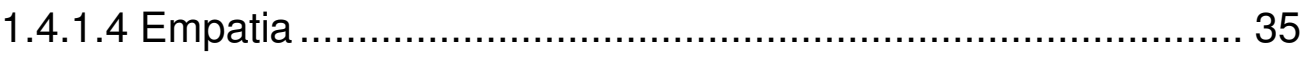

1.4.1.5 Aceitação positiva incondicional...................................... 36

1.5 Utilização da Teoria do Cuidado Humano ......................................... 39

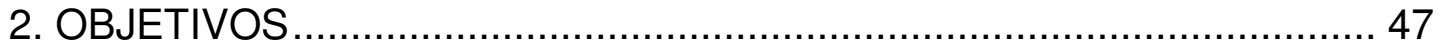

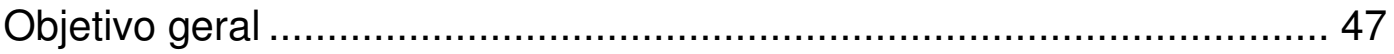

Objetivos específicos ............................................................ 47

3. ASPECTOS METODOLÓGICOS ................................................. 48

3.1 Tipo de estudo........................................................................ 48

3.2 Tratamento e análise dos dados ............................................... 49

3.3 Procedimento para coleta dados ................................................ 51

3.4 Cenário da pesquisa e participantes ............................................ 56

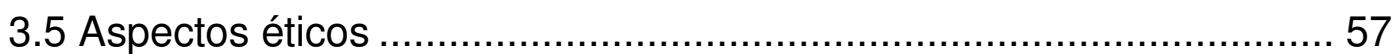

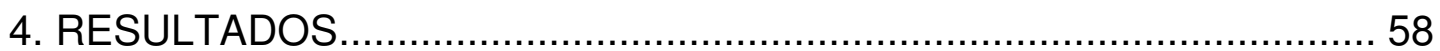

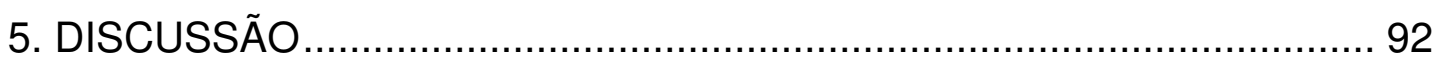

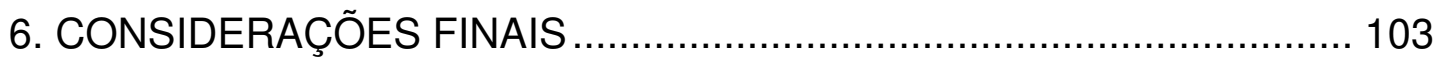

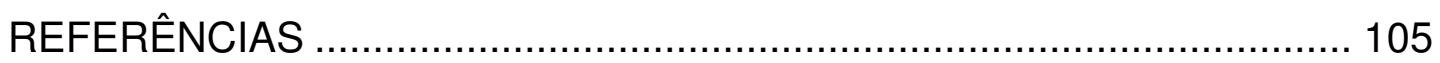

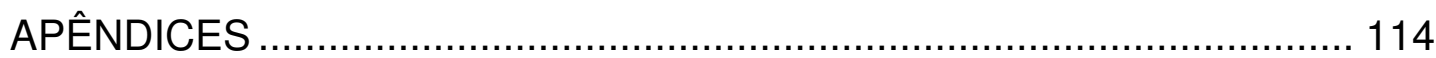




\section{INTRODUÇÃO}

A área da enfermagem pediátrica me despertou especial atenção, quando eu ainda estava na graduação, pelo desafio em atender e entender as necessidades de uma criança dentro do hospital. Quando passei pela disciplina: Enfermagem da criança e da família na experiência de doença, em 2008, aprendi sobre o cuidado centrado na criança e na família e os modelos teóricos que propõem a avaliação e intervenção, como o de Wright e Leahey (2009). Conheci a grandeza e quantidade de subsídios interessantes que podemos adotar, na enfermagem, para cuidar de famílias. Mas, ao mesmo tempo, diversas inquietações me provocaram para entender como, de fato, os profissionais prestavam atenção aos familiares da criança e da forma como expressavam esse cuidado.

O contato com as famílias durante o estágio dessa disciplina, assim como, a orientação dos professores para realizarmos avaliação e intervenção com pelo menos uma família, fizeram-me perceber como a doença traz diversas consequências para cada um de seus membros. Adicionalmente, pouco tempo depois com experiências pessoais pude entender o quanto, naturalmente, reajustam-se nossos papéis, para cuidar de um familiar que passa por uma situação de doença.

Assim, decidi que gostaria de aprofundar-me na pesquisa sobre 0 cuidado de enfermagem prestado às crianças e às famílias. Paralelamente, recebi o apoio da Prof. ${ }^{-}$Dr. ${ }^{-}$Regina Szylit Bousso, quem havia me acompanhado no estágio de enfermagem pediátrica. Naquela ocasião, dei continuidade a um projeto do grupo de pesquisa, que se tornou minha iniciação científica. O estudo teve como objetivo desvelar os elementos do cuidado humanizado presentes no encontro entre o enfermeiro, a família e a criança com câncer e verificar em que situações o profissional de enfermagem percebe que a humanização está ancorada ao cuidado. Para análise dos dados, utilizamos a Teoria do Cuidado Humano de Watson (2008), quando aprendi pela primeira vez sobre esse referencial. Com os resultados, percebemos que muitos elementos teóricos estão presentes nos discursos dos enfermeiros, mas são pouco relacionados com atitudes de 
cuidado para atender às necessidades e amenizar o sofrimento da criança e da família. Assim, outras indagações surgiram: De que forma os enfermeiros reconhecem os referenciais teóricos para o cuidado de enfermagem? Como compreendem um referencial na sua vivência prática? $\mathrm{E}$ de que maneira ele pode ajudar o enfermeiro no cuidado de crianças e famílias que vivem uma experiência de uma doença?

Conhecendo um pouco mais o referencial, fiquei interessada pela forma como Watson (2008) enfoca o relacionamento de cuidado. Para ela, trata-se de um encontro sensível entre enfermeiros, pacientes e famílias, capaz de repercutir em todos os envolvidos nessa relação. A partir desse olhar, percebi como realmente precisávamos, enquanto profissão essencialmente voltada para o cuidado, prestar mais atenção à maneira como promover esse encontro.

Com a iniciação científica, tive a oportunidade de participar de dois congressos que me ajudaram a amadurecer essas idéias. Um deles foi o III Congresso Brasileiro de Enfermagem Pediátrica e Neonatal, que ocorreu em outubro de 2009, em Florianópolis, onde pude discutir sobre o estudo e conhecer outros alunos e professores que compartilhavam o interesse na área do cuidado de enfermagem, em pediatria. Com esse estudo também ganhei um auxílio para participar da $31^{\text {st }}$ International Association for Human Caring Conference, em 2010, em Rochester, EUA. Nessa ocasião, pude conhecer diversos trabalhos que utilizavam teorias de enfermagem, assim como uma instituição em que os enfermeiros baseavam suas ações em referenciais, como o de Jean Watson. Foi de extrema importância para este estudo, conhecer os programas americanos com a finalidade de aproximar referenciais teóricos da prática do cuidado, possibilitando exercer uma assistência de enfermagem centralizada no cuidar, como forma de expressão no encontro do enfermeiro, seja com o paciente, seja com a família ou mesmo com outros profissionais de saúde.

Ademais, outros trabalhos realizados pelo nosso grupo de pesquisa: Núcleo Interdisciplinar de Pesquisas em Perdas e Luto (NIPPEL), bem como, com parcerias de pesquisadores de outras universidades, especialmente pela vinda de professores visitantes, contribuíram para a 
decisão de trabalhar, especificamente, com a questão do relacionamento de cuidado. Esses estudos mostram que enfermeiros, embora sensibilizados para trabalhar com famílias, ainda têm dificuldades para iniciar esse contato (Silva, 2010; Moules et al., 2010).

Dessa forma, com base em resultados de pesquisas e nos fundamentos da Teoria do Cuidado Humano de Jean Watson, apresentamos este estudo, acreditando trazer contribuições para melhor compreender os fatores envolvidos nas interações entre enfermeiros e famílias de crianças internadas, bem como, a forma como o referencial pode ajudá-los a desenvolver a relação de ajuda e confiança com esses familiares.

\subsection{O CUIDADO NO ATENDIMENTO EM SAÚDE}

Uma vasta literatura nas mais diversas áreas de conhecimento vem retratando uma preocupação de incluir a dimensão humana nas relações de saúde. Alguns estudos apontam para o termo "humanização", vinculando ou não a palavra cuidado. No Brasil, percebe-se um movimento especial das ciências sociais e biológicas, particularmente a medicina e a enfermagem, a partir de 2000, com a regulamentação do Programa Nacional de Humanização da Assistência Hospitalar (PNHAH), pelo Ministério da Saúde. Esta iniciativa tem como objetivo fundamental o aprimoramento das relações entre profissionais, usuários/profissionais e hospital/comunidade, visando melhorar a qualidade e a eficácia dos serviços prestados pelas instituições, promovendo uma nova cultura de atendimento (Brasil, 2000). Com o intuito de implantar uma cultura transversal, permeando a assistência e descaracterizar a política de humanização como um programa específico, o Ministério instituiu, em 2004, o HumanizaSUS (Brasil, 2004).

Em um amplo conjunto de iniciativas para humanização, diversos programas avançaram e os profissionais se defrontaram com uma nova demanda para a atenção em saúde que envolve mudança na cultura e abertura para novos conhecimentos teóricos (Deslandes, 2004). Dessa perspectiva para a real mudança na prática assistencial, um grande caminho ainda precisa ser percorrido. Para Ayres (2004), trata-se de uma 
(des)construção teórico-filósófica para uma (re)construção das práticas de saúde, com ênfase no cuidado.

Trata-se de um processo que exige ênfase ampla e coletiva, não apenas do ser cuidado, foco da relação, mas também da preocupação com a estruturação do ambiente e dos profissionais, para que todos usufruam de segurança e conforto (Waldow, 2011). Envolve também a ética e a estética, o que pressupõe além da técnica, sensibilidade para que os indivíduos formalizem a consciência com o cuidado (Waldow, 2008).

Além da ênfase para a integralidade da atenção, ocorre que humanização é uma expressão de difícil conceituação, tendo em vista seu caráter subjetivo, complexo e multidimensional. (Simões et al., 2007). Para autoras, humanizar "é afirmar o humano na ação e isso significa cuidado porque só o ser humano é capaz de cuidar no sentido integral' (Waldow, Borges, 2011).

Sendo o cuidado, objeto central das relações de saúde, inerente aos valores humanos, alguns autores (Ayres, 2005; Oliveira, Zampieri, Brüggemann, 2001; Waldow, Borges, 2011) consideram redundante o termo cuidado humanizado ou humanização do cuidado. Olhando por esta ótica argumentam que as atitudes de cuidado são por si humanizadas, envolvendo responsabilidade, interesse pelo outro e comprometimento moral e, sendo assim, ambas as categorias, cuidado e humanização envolvem e revelam a dignidade humana como foco da ação (Waldow, 2011).

Ayres (2005) sob uma visão mais teórica e filosófica propõe por meio da hermenêutica uma revisão dos significados e nas práticas das organizações de saúde, a respeito da humanização. As interações de saúde são reduzidas ao paradigma das tecnociências, ao mesmo tempo que percebem a limitação desse conhecimento para exercer os processos dialógicos, revelando um paradoxo nos discursos que ajuda a compreender "por que uma das mais expressivas expressões do modo de ser do humano, o cuidado, esteja buscando...humanizar-se!".

Considerar a dimensão humana no atendimento de saúde significa valorizar e perceber a subjetividade na base de toda intervenção, das mais simples às mais complexas, tendo influência na eficácia dos serviços 
prestados pelos hospitais. A humanização ou o cuidado é um processo amplo e complexo, que oferece resistência, pois envolve mudança de comportamento e sempre desperta insegurança (Beck et al., 2007). O processo de socialização para preparar profissionais competentes e sensíveis como provedores de cuidado é um grande desafio para as organizações de saúde (Costa, Lunardi, Soares, 2003).

\subsection{O CUIDADO E A ENFERMAGEM}

A enfermagem dedica-se especialmente aos discursos que enfocam o cuidado e/ou as práticas da humanização nas organizações de saúde, por tratar-se de uma profissão que lida de forma muito próxima com seres humanos em situação de fragilidade e vulnerabilidade. Embora essas questões apareçam com grande relevância na literatura atual, é a partir das contribuições de Florence Nightingale que a enfermagem adquire bases científicas para se constituir como profissão com a especificidade de cuidar do outro, fundamentado nos preceitos religiosos de caridade, amor ao próximo, doação, humildade e ao mesmo tempo autoridade, divisão do trabalho e controle do ambiente de cuidado.

O advento dos avanços tecnológicos, no século $X X$, direcionou e influenciou a enfermagem para uma perspectiva biomédica e paradigmática. A ênfase passou a ser maior nos aspectos técnicos e nas tarefas, bem como para a cura das enfermidades (Waldow, 2008). Além disso, no Brasil, a divisão social do trabalho de enfermagem agregou diferentes atribuições ao profissional enfermeiro e àqueles de nível técnico, relacionando ao primeiro as atividades mais administrativas do cuidado e organização do trabalho e ao segundo o papel assistencial, concretamente. Não apenas na equipe de enfermagem, mas a divisão social e hierárquica na equipe multiprofissional prejudicam a integração das práticas assistenciais e terapêuticas que revelem a integralidade da saúde, em substituição à racionalidade biomédica (Peduzzi, 2007). Para Peduzzi (2007) não é um processo que deve acabar com as diferenças técnicas dos diferentes saberes, mas integrar a partir de 
um mesmo horizonte normativo, um conjunto de valores comuns dentro e entre as equipes.

Entre a década de 60 e 70, nos Estados Unidos, surgem várias teorias e modelos de enfermagem voltados tanto para os aspectos técnicos da profissão, como para o estudo do cuidado como objeto central dessa carreira. Muitos desses modelos trouxeram influência para o Brasil, a exemplo do processo de enfermagem e diagnósticos pautados nos modelos norte americanos. Outros referenciais estão mais voltados para aspectos psicológicos, sociais e emocionais do cuidado, tal como as teorias de Watson (2008), Leininger (1991), Orem (1990) e Boykin (1994), por exemplo. Entretanto, Waldow (2006) argumenta que essas teorias não adquiriram em outros locais, o mesmo potencial que nos países norte americanos.

Segundo Waldow (2008), hoje, a enfermagem abrange uma heterogeneidade de conhecimentos do processo de cuidar. Existem as competências administrativas, gerenciais, da prática clínica, processo de enfermagem e, também, um enfoque voltado para as questões humanísticas do cuidado. Essa mesma autora ainda defende que esse resgate do cuidado na prática da enfermagem não rejeita o conhecimento teórico e científico. Pretende-se, portanto, enaltecer os processos interativos na relação de saúde, ligados aos aspectos emocionais, artísticos, éticos e morais do cuidado.

Talvez, se compreenda como um dos maiores desafios, atualmente, da enfermagem e das instituições de saúde a necessidade de trazer o resgate do cuidado para as diversas atribuições que the conferem nas práticas de prevenção de doenças, promoção, recuperação e reabilitação da saúde. Adicionalmente, o cuidado deve abranger não apenas o ser humano individualmente, mas também a família e a comunidade, visando responder às necessidades de saúde que se estendem a todos os aspectos da vida do ser humano, considerado em sua integralidade, nas relações sociais, trabalho e projetos futuros. Assim, pensar o cuidado, também, com o foco de atenção na família pressupõe um modelo assistencial que leva em conta o meio social, o estilo de vida e a promoção da saúde, como seus fundamentos básicos (Rocha, Almeida, 2000). 


\subsection{A ENFERMAGEM E O CUIDADO CENTRADO NA CRIANÇA E NA FAMÍLIA}

A família é vista como a base da socialização dos indivíduos e unidade responsável por prover proteção e aprendizado para as primeiras interações e para o desenvolvimento do afeto (Carvalho, 2000). Entre as várias definições de família nos diferentes campos de estudo, Elsen, Althoff e Manfrini (2001) a conceituam como:

uma unidade dinâmica, com uma identidade que the é peculiar, constituída por seres humanos unidos por laços de sangue, de interesse e/ou afetividade, que se percebem como família, que convivem por um espaço de tempo construindo uma história de vida (p.93).

Wright, Watson e Bell (1996) referem-se à família como "um grupo de indivíduos unidos por fortes vínculos emocionais, um senso de pertencer e a inclinação a participar das vidas uns dos outros". Para a enfermagem, na clínica é mais aplicável aceitar que pertencem à família os indivíduos cujos membros dizem que são (Whight, Leahey, 2009). Nesta perspectiva, pressupõe-se que os indivíduos estão unidos por laços relacionais, que são capazes de manter o sistema equilibrado em busca de metas para o bem estar. O enfermeiro percebe o movimento dos indivíduos pela interação para que ações sejam promovidas, facilitadas pela compatibilidade dos ideais.

O reconhecimento da importância da família no processo de saúdedoença é anterior à institucionalização da saúde, já que o foco do cuidado era realizado no ambiente familiar e todo o processo ocorria no domicílio (Antunes, Egry, 2001). Na enfermagem, Florence Nightingale mencionava a importância da participação da família no cuidado dos militares, porém pensar família foi gradativamente perdendo espaço pelo crescente desenvolvimento da tecnologia, da qualificação dos profissionais e pela institucionalização do cuidado ao longo do tempo (Friedman, Bowden, Jones, 2003). Wright e Leahey (2009) ainda ressaltam que esse espaço foi diminuindo não apenas nas situações de doença, mas também de eventos familiares importantes, como nascimento e morte. 
Alguns avanços ocorreram com a introdução do termo medicina centrada no paciente e mais tarde como cuidado centrado no paciente, pelo Packer Institute. A partir desta preocupação, vários estudos buscavam incorporar as necessidades e preferências dos pacientes como fundamentais nos modelos de cuidado (IFCC, 2008).

No final da década de 1970, profissionais de saúde voltaram-se para o desenvolvimento de uma atenção mais sistematizada à família, procurando a criação de práticas que atendessem as necessidades de seus membros. Esse novo foco evoluiu como campo prático e de intervenção, na medicina de família e comunidade, enfermagem familiar e terapia familiar (Bruns, 2002). O IFCC (Institute for Family-Centered Care), fundado em 1991, integrou avanços para a prática do cuidado a pacientes e famílias, através da disseminação de materiais, pesquisas e iniciativas para estabelecer parcerias entre hospitais, pacientes e famílias.

A enfermagem tem o compromisso e a obrigação de incluir as famílias nos cuidados da saúde. A evidência teórica e prática do significado que a família dá para o bem estar e a saúde de seus membros, bem como sua influência sobre o processo saúde-doença obriga as enfermeiras a considerar o cuidado centrado na família como parte integrante da prática de enfermagem (Wright e Leahey, 2009). Bomar (2004) afirma que o processo de aumentar a capacidade das famílias em promover saúde é uma responsabilidade fundamental da enfermagem.

Enfermeiros, em sua prática cotidiana, têm oportunidade única de trabalhar com famílias. Wright e Bell (2004) afirmam que entre as áreas de trabalho da enfermagem, a enfermagem de comunidade é uma das que trazem maior ênfase no trabalho com famílias. Ainda assim, afirmam as autoras, mesmo na comunidade a enfermagem de família não é realizada integralmente. São muitos os fatores que impedem ou inibem enfermeiras a desenvolverem um trabalho com famílias, entre eles, as crenças sobre falta de tempo e falta de capacitação para abordarem questões familiares, a falta de preparo real das enfermeiras para a prática com famílias, a falta de referenciais teóricos e instrumentos que viabilizem esta prática. 
Bousso (2006) afirma que hoje os enfermeiros estão mais conscientes da necessidade e de seu compromisso de incluir a família no cuidado. Entretanto, também reconhece a dificuldade que os profissionais têm encontrado em implementar práticas com famílias, devido à falta de um referencial teórico e de instrumentos, de modo que a estratégia para a reaproximação seria criar um contexto, no qual enfermeiras e famílias pudessem estabelecer uma relação de parceria na qual a confiança, comunicação regular e transparência, bem como a cooperação para atender as necessidades da família, sejam asseguradas.

Assim sendo, o termo cuidado centrado no paciente e na família, origina-se de esforços para construir uma experiência que envolva a família na colaboração, planejamento e implementação dos diversos recursos de saúde. Esse modelo teria ênfase no atendimento de pacientes de todas as idades, quaisquer sejam seus problemas de saúde e em qualquer instituição, reconhecendo a família, independente de sua definição, como essencial para a saúde e bem estar dos pacientes, além de poderosos aliados na garantia da qualidade e segurança dentro dos sistemas de saúde (IFCC, 2008).

Os membros da família, entretanto, não devem ser encarados como substitutos a serem cobrados, quando algum paciente for incapaz de tomar decisões ao seu favor, e sim como um membro essencial no cuidado e também como unidade passível de cuidado. O isolamento social da família é um fator de risco para a saúde, e, portanto, as instituições não devem separá-los do cuidado e das tomadas de decisão (IFCC, 2008).

Os pressupostos centrais para o cuidado centrado na família, apresentados pelo Instituto para o Cuidado Centrado na Família são: dignidade e respeito; reconhecer as escolhas do paciente e da família, a partir das próprias crenças, valores e cultura, que devem ser incorporados ao planejamento e prestação de cuidado; compartilhar informações que inclui comunicar-se com a família e dividir as informações úteis de maneira completa e imparcial, para que possam participar efetivamente do cuidado e nas tomadas de decisão; participação, de forma que os pacientes e famílias sejam encorajados e apoiados em participar do cuidado e da tomada de 
decisão, no nível que escolherem; colaboração, entre paciente, família, profissionais e líderes das instituições para o desenvolvimento, implantação e avaliação das políticas e programas, na facilitação dos cuidados à saúde, na educação profissional e na prestação de cuidado (IFCC, 2008).

Nesse panorama, o cuidado centrado na família tem por objetivo garantir, principalmente, a saúde e o bem estar de cada paciente dentro do seu contexto de vida. É importante ressaltar que a definição de família é referida pelos seus próprios membros e não pela equipe, e a esta cabe atendê-la em todas as suas necessidades além do corpo físico, prestando suporte emocional, social e psicológico em vista ao desenvolvimento desta, enquanto unidade de cuidado (IFCC, 2008).

A noção de família enquanto unidade tem como premissa o olhar para a família como um todo a partir da perspectiva de sistema. O referencial teórico difundido na literatura é a teoria geral dos sistemas, introduzida em 1936 por von Bertalanffy e utilizada pelos profissionais de saúde para aplicação com família. A partir da compreensão de sistemas, como um complexo de elementos em mútua interação, o foco para a assistência de enfermagem seria na interação dos membros e não no atendimento individual, embora tenha relação direta (Wright e Leahey, 2009).

Esses conceitos permitem a aplicação clínica nos atendimentos dos profissionais às famílias e são modelos para guiar essas intervenções. Whight e Leahey (2009) sintetizam os principais conceitos da teoria de sistemas familiares para a aplicação na enfermagem:

- Um sistema familiar é parte de um supra-sistema mais amplo, e por sua vez, é composto por muitos subsistemas.

- A família, como um todo, é maior que a soma de suas partes.

- A mudança em um membro da família afeta a todos na família.

- A família é capaz de gerar um equilíbrio entre mudança e estabilidade.

- Os componentes dos membros da família são mais bem compreendidos sob um ponto de vista de uma causalidade circular e não linear.

(p. 22-26) 
O desenvolvimento de habilidades que possibilitem atuar com competência junto à família será sempre um desafio. No Brasil, a enfermagem pediátrica vem contribuindo de forma expressiva com pesquisas que buscam aprimorar a visão do cuidado centrado na família (Pinto et al., 2010).

Nesse amplo processo de reestruturação do cuidado, adiciona os desafios da assistência à criança que congruente à política de humanização deve preservar este indivíduo na unicidade do ser em seu contexto próprio. Vivenciar uma internação é algo desconfortável para qualquer individuo e envolve diversos sentimentos, que pode ser ainda mais frágil e complicado na infância, por se tratar de uma pessoa dependente para a sobrevivência, ainda em formação e com dificuldades em compreender a doença (Gomes, Erdmann, 2005). Nesse contexto, a família como um todo passa por uma desestruturação, justificada pela mudança na rotina, em decorrência da hospitalização, além das crenças que cercam a doença e do estresse decorrente da situação (Pauli, Bousso, 2003).

Desta forma, o profissional de enfermagem, que passa muito tempo com a criança e familiares, ao se deparar com esse ambiente deve buscar artifícios que vão além da técnica e fazer do cuidar uma arte com habilidade empática e criativa. Por isso, é necessário compreender o sentido do cuidar e a subjetividade que envolve esse processo, com atenção especial ao universo da criança, preservando o seu mundo particular e as etapas de desenvolvimento da infância para satisfazer suas necessidades em troca do bem estar, apesar da condição de doença (Barbosa, Rodrigues, 2004).

Nessa perspectiva humana do cuidado à criança, grandes avanços ocorreram no Brasil após 1990, com Estatuto da Criança e do Adolescente, atribuindo o direito da "permanência em tempo integral de um dos pais ou responsável, nos casos de internação de criança ou adolescente" (Brasil, 1990). Este panorama contribuiu para que o cuidado pudesse integrar a família como unidade no atendimento de saúde. Esta mudança na dinâmica das instituições de saúde no setor de pediatria, no Brasil, traz uma perspectiva favorável ao processo de humanização, pois a presença dos pais além de contribuir para a qualidade do atendimento, também é uma 
referencia da criança para fortalecimento do carinho e segurança nesse momento de fragilidade (Franquinello, Higarashi, Marcon, 2007).

Diante da complexidade em promover um ambiente de cuidado centrado na criança e suas famílias, a enfermagem tem a possibilidade de realizar suas ações embasadas em referenciais específicos que norteiam a prática. Modelos que propõe avaliação e intervenção com a família, como de Wright e Leahey (2009) já têm sido assimilados e utilizados pelos enfermeiros na prática, no entanto, estudos mostram que o maior desafio para esses profissionais é o engajamento inicial com a família (Moules et al., 2010; Silva, 2010). Assim, procuram mecanismos para ajudá-los a iniciar esse relacionamento.

Um estudo que teve como objetivo conhecer a experiência de enfermeiros do Programa de Saúde da Família na aplicação da entrevista de 15 minutos, proposta pelas enfermeiras canadenses Lorraine Wright e Maureen Leahey, mostrou que os enfermeiros tem dificuldade em se arriscar no processo de engajamento com as famílias que atendem. O profissional sente-se constrangido e inseguro diante do desafio de introduzir uma nova prática a uma rotina já estabelecida - o cuidado centrado na família (Silva, 2010).

Este tema aparece também na literatura internacional. $O$ estudo que analisou a natureza das relações de trabalho das enfermeiras de saúde pública e as famílias de alta prioridade em pequenas comunidades no norte do Canadá conclui que os enfermeiros negociam cuidadosamente o processo de envolvimento com família, mantendo as relações nos limites de negociação para o cuidado (Moules et al., 2010).

O engajamento com a família, no início do cuidado, pautado em uma relação de ajuda e confiança é essencial para que o profissional possa aprofundar sua interação com ela a fim de conhecer as percepções e necessidades da família, favorecendo as intervenções.

Assim, pensando em elementos que possam favorecer o inicio da interação do enfermeiro com a família, buscamos a Teoria do Cuidado Humano de Watson (2008) que envolve em um dos seus aspectos o estabelecimento da relação de ajuda e confiança no cuidado, que favorece a 
aproximação do profissional com familiares de crianças internadas. Dessa maneira, acreditamos trazer contribuições acerca do pensar cuidado, tendo como foco as interações dos profissionais com as famílias.

A Teoria do Cuidado Humano de Jean Watson está pautada em fundamentos fenomenológicos - existenciais e percebe o cuidado como um momento de encontro entre sujeitos passíveis de transformação. Esse momento deve enaltecer os valores, sentimentos e emoções do enfermeiro, do paciente e da família para que o profissional possa reconhecer melhor as próprias limitações, bem como as crenças e expectativas da família e do paciente.

Baseando-se em pressupostos humanísticos para fundamentar a enfermagem enquanto base científica do cuidado, esse referencial pode ser visto em diversos estudos, abordando sua utilização em diferentes contextos da prática dos enfermeiros, razões que influenciaram na escolha da teoria de Jean Watson como proposta para contribuir no processo de cuidar (Rafael, 2000; Saewyc, 2000; Sessanna, 2003; Stamm, 2000; Lacerda, 1997; Cara, 2003; Norman, et al., 2008; Nascimento, Erdmann, 2006; Paganini, 2000). Acreditamos que, por esse referencial considerar como fundamentos básicos para o cuidado o resgate dos valores humanos, a consciência e a intencionalidade das ações, ele pode contribuir para quebrar barreiras que dificultam o momento do encontro dos enfermeiros com as famílias. Dessa forma, pode complementar outros referenciais mais específicos de avaliação e intervenção com famílias (Wright e Leahey, 2009) ou mesmo servir de base para o cuidado centrado na criança e na família.

\subsection{A TEORIA DO CUIDADO HUMANO DE JEAN WATSON}

A Teoria do Cuidado Humano de Jean Watson (2008) traz um resgate de Florence Nightingale com relação ao papel da enfermeira frente ao cuidado, uma profissão que envolve um chamado interior para o exercício sublime do cuidar. Assim, pode-se compreender as dimensões do amor, calidez e compassividade, como possibilidade de exteriorização em razão do cuidado, assim como em atitudes da vida (Nightingale, 1989). 
As teorias fornecem conceitos relevantes, que buscam identificar características e validá-las na prática, mediante à pesquisa. Assim, elas propõem um determinado método para fundamentar os fenômenos evidentes na prática, fortalecendo a enfermagem como base científica. Sendo assim, as teorias de enfermagem devem representar uma forma prática de intervenção, para o desenvolvimento teórico contínuo. A escolha de um referencial deve considerar a adequação e aplicabilidade à situação que é desejada, visando a novas diretrizes e reconstruções (Carraro, 2001).

A teoria desenvolvida por Jean Watson trouxe inovações para 0 conceito do cuidado. A Teoria do Cuidado Humano, como foi inicialmente denominada pela autora:

\begin{abstract}
emergiu da busca para trazer novos significados e dignidade para o mundo da enfermagem e do cuidado do paciente e também para as experiências de vida subjetivas do próprio self e dos outros. Também proporciona fundamentos éticos - filosóficos para as dimensões humanas mais profundas da enfermagem (Watson, 1997: 49).
\end{abstract}

Os elementos teóricos surgiram das experiências profissionais e pessoais da autora, foram induzidos clinicamente e fundamentados empiricamente, combinando um arsenal filosófico, intelectual e experimental. Alguns questionamentos sobre vida, morte, cuidado, cura, entre outros, guiaram a teoria com o intuito de buscar um referencial para a enfermagem, como uma disciplina própria, uma entidade e uma profissão com peculiaridades distintas da medicina e ao mesmo tempo complementares (Watson, 2007).

Inicialmente publicada em 1979, no livro "Nursing: The Philosophy and Science of Caring", a Teoria do Cuidado Humano traz a união dos valores humanos e das bases científicas para guiar as ações de enfermagem como dois fatores importantes para a ciência do cuidado. Através dos carative factors, proposto por Watson nesse livro, a interação de ciência e humanismo se organiza como um guia para a alma da enfermagem na prática consciente do cuidado. (Watson, 1979). O termo carative foi introduzido para contrastar com a palavra 'curativo' da medicina tradicional. O propósito desses fatores era "honrar a dimensão humana do trabalho de 
enfermagem e a vida interior, bem como as experiências subjetivas das pessoas que servimos" (Watson, 1997: 50).

Para apresentar os carative factors foram estabelecidas sete premissas básicas para o cuidado, partindo das atribuições de um enfermeiro para promover e restaurar a saúde, prevenir a doença e cuidar do doente. Portanto, é tradicionalmente parte da enfermagem integrar o conhecimento biológico ao comportamento humano para promover bem estar no cuidado e dar ênfase na promoção da saúde mais do que no tratamento de uma doença especializada, como tendência das ações em saúde. Por ocasião desse foco, a enfermagem envolve mais o conceito do cuidado - care - do que da cura - cure - que são diferentes, embora complementares, porém esse último mais próximo do domínio médico.

As premissas básicas para a ciência do cuidado na enfermagem, segundo Watson, são mostradas a seguir (Watson, 2008).

- A ciência do cuidado é a essência da enfermagem e o alicerce na disciplina da profissão.

- O cuidado pode ser efetivamente demonstrado e praticado interpessoalmente, porém, a consciência do cuidado pode ser comunicada além/ transcendendo 0 físico, o tempo e o espaço (Watson, 2002).

- O processo intersubjetivo humano-humano e suas conexões mantém vivo o sentido comum de humanidade; ele nos ensina como ser humano, identificando nós mesmo nos outros (Watson, 1985).

- O cuidado consiste de carative factors/caritas processes que facilitam a cura, honram o todo e contribuem para a evolução da humanidade.

- Um cuidado efetivo promove saúde, cura, crescimento individual/ familiar e um senso da totalidade, do perdão, da consciência desenvolvida e a paz interior que transcende a crise, o medo da doença, diagnósticos, traumas, mudanças de vida e assim por diante.

- Responder o cuidado é aceitar a pessoa não apenas como ele ou ela está agora, mas pelo o que ele ou ela possam vir a ser/ tornar-se.

- Um relacionamento de cuidado é aquele que convida a revelação do espírito humano, possibilitando o autentico potencial, estando presente e permitindo à pessoa escolher a melhor ação para si mesma, num determinado ponto no tempo.

- O cuidado é mais saúde do que cura.

- A ciência do cuidado é complementar a ciência do curar. 
- A prática do cuidado é essencial para a enfermagem. Suas contribuições sociais, morais e científicas inclinamse para o comprometimento profissional de valor, ética e ideais da ciência do cuidado na teoria, na prática e na pesquisa.

Em 1985 com o livro, Nursing: Human Science and Human Care, a Theory of Nursing, Watson introduziu algumas alterações ao envolver conceitos como ocasião de cuidado, campo fenomenológico e o paradigma do cuidado transpessoal, o qual enfoca: o ideal moral, o significado da comunicação e do contato intersubjetivo mediante a co-participação do self como um todo (Watson, 1985). A maior ênfase para a teoria, depois desse livro, foi em explicitar o reconhecimento das dimensões espirituais do cuidado e no processo de cura.

O amadurecimento da teoria foi ao longo do tempo revelando a ciência do cuidado como "ponto de partida" para a enfermagem enquanto disciplina, oferecendo uma base para a profissão e para o cuidar, baseados em paradigmas metafísicos, filosóficos e morais, com respeito ao significado do ser humano em sua unidade e totalidade de mente-corpo-espírito (Watson, 2008).

Com a evolução de sua teoria, Watson, introduziu o conceito de clinical caritas processes que ampliaram as definições dos carative factors. Seu objetivo era que pudesse ser observada uma dimensão espiritual maior nos novos processos e identificado mais claramente a conexão entre o cuidado e o amor, como um campo mais amplo. Desta forma, os caritas processes permitiam redefinições mais significativas do fenômeno Caritas Nursing, em contraposição ao Carative Nursing. Esses novos significados incluem um vocabulário de cuidado na perspectiva ontológica, para refletir numa nova maneira de pensar nessa prática, relacionando aspectos entre 0 cuidado, o amor e processos humanos (Watson, 2008).

A palavra caritas é do latim e significa tratar com carinho, amar, estimar, dar atenção especial. A incorporação dessa denominação para representar a essência da enfermagem, enquanto ciência do cuidar, tem por base a caridade, a compaixão e generosidade de espírito, como algo muito próximo e que precisa ser mantido e cultivado. 
Os carative factors e clinical caritas processes podem aparecer na literatura traduzidos como fatores de cuidado (Nascimento, Erdmann, 2006; Paganini, 2000; Pai, Lautert, 2005; Silva et al., 2002) e fatores caritativos (Watson, 2007), respectivamente. Utilizamos neste estudo somente a tradução das palavras factors e processes, como fatores e processos para nos referirmos a esses fenômenos. As palavras carative e caritas optamos por mantê-las tal como foi apresentado por Jean Watson (2008), acreditando que a tradução não expressa o sentido da palavra derivada do latim.

No quadro 1 encontram-se os carative factors e os clinical caritas processes (Watson, 2007; Watson, 2008).

Quadro 1 - Descrição dos carative factors (1979) e caritas processes (20022007)

\begin{tabular}{|c|c|}
\hline Carative Factors (1979) & Caritas Processes 2002-2007 \\
\hline $\begin{array}{l}\text { A formação de um sistema de } \\
\text { valores humanístico - altruísticos }\end{array}$ & $\begin{array}{l}\text { Prática do amor, bondade e } \\
\text { equanimidade para si e para o outro. }\end{array}$ \\
\hline Promoção da fé - esperança & $\begin{array}{l}\text { Estar autenticamente presente; permitir/ } \\
\text { sustentar/ respeitar profundamente o } \\
\text { sistema de crenças e o mundo } \\
\text { subjetivo do self/outro. }\end{array}$ \\
\hline $\begin{array}{l}\text { Cultivo da sensibilidade para si } \\
\text { mesmo e para os outros }\end{array}$ & $\begin{array}{l}\text { Cultivar suas próprias práticas } \\
\text { espirituais; } \\
\text { autoconsciência, para além do ego. }\end{array}$ \\
\hline $\begin{array}{l}\text { Desenvolvimento de uma relação } \\
\text { de ajuda - confiança }\end{array}$ & $\begin{array}{l}\text { Desenvolvimento e permanência de } \\
\text { uma autêntica relação de cuidado, de } \\
\text { ajuda e confiança. }\end{array}$ \\
\hline $\begin{array}{l}\text { Promoção e a aceitação da } \\
\text { expressão de } \\
\text { positivos e negativos }\end{array}$ & $\begin{array}{l}\text { Estar presente e apoiar a expressão de } \\
\text { sentimentos positivos e negativos, } \\
\text { como uma conexão profunda com o } \\
\text { espírito do ser e do ser que cuida do } \\
\text { outro }\end{array}$ \\
\hline $\begin{array}{l}\text { Uso sistemático do método de } \\
\text { resolução de problemas para } \\
\text { tomada de decisão (redefinido em } \\
\text { 1985: uso do processo de cuidado } \\
\text { criativo na resolução de } \\
\text { problemas) }\end{array}$ & $\begin{array}{l}\text { Uso criativo do ser, de todas as formas } \\
\text { de conhecer/ser/fazer, como parte do } \\
\text { processo de cuidado (engajando } \\
\text { artisticamente a prática do cuidado) }\end{array}$ \\
\hline $\begin{array}{l}\text { Promover ensino-aprendizagem } \\
\text { interpessoal }\end{array}$ & $\begin{array}{l}\text { Engajamento em uma experiência } \\
\text { genuína de ensino-aprendizagem que }\end{array}$ \\
\hline
\end{tabular}




\begin{tabular}{|c|c|}
\hline & $\begin{array}{l}\text { atenda a pessoa como um todo; } \\
\text { tentando permanecer na estrutura } \\
\text { referencial do outro. }\end{array}$ \\
\hline $\begin{array}{l}\text { Provisão de um ambiente de } \\
\text { apoio, proteção e/ou correção } \\
\text { mental, física, sócio-cultural e } \\
\text { espiritual. }\end{array}$ & $\begin{array}{l}\text { Criar um ambiente protetor em todos os } \\
\text { níveis, onde se está consciente do } \\
\text { todo, da beleza, do conforto, da } \\
\text { dignidade e da paz }\end{array}$ \\
\hline $\begin{array}{l}\text { Assistir as necessidades humanas } \\
\text { com satisfação/ gratificação }\end{array}$ & $\begin{array}{l}\text { Assistir com respeito as necessidades } \\
\text { básicas, mantendo um cuidado } \\
\text { intencional e consciente do espírito, } \\
\text { enquanto unidade do ser. }\end{array}$ \\
\hline
\end{tabular}

\begin{tabular}{|c|c|c|}
\hline $\begin{array}{l}\text { A permissãc } \\
\text { fenomenológica } \\
\text { (redefinida em } \\
\text { existências - } \\
\text { espirituais) }\end{array}$ & $\begin{array}{r}\text { de forças } \\
-\quad \text { existenciais } \\
85: \text { dimensões } \\
\text { fenomenológico- }\end{array}$ & $\begin{array}{l}\text { Estar presente e aberto para as } \\
\text { dimensões existenciais desconhecidas } \\
\text { do sofrimento entre vida-morte; } \\
\text { "permitindo um milagre" * }\end{array}$ \\
\hline
\end{tabular}

${ }^{*}$ Idea courtesy Resurrection Health, Chicago.

O cuidado deve ter um foco especial para as relações interpessoais, uma vez que os momentos do cuidar são expressões da maneira como interagem duas ou mais pessoas. Para Watson (2008) o desenvolvimento dessa interação pode ocorrer de maneira transpessoal, buscando o estabelecimento da relação de ajuda e confiança. O paradigma transpessoal é a idéia de estabelecer uma convivência que ultrapassa o atendimento das necessidades inferiores, partindo para um nível mais elevado e resultando em uma transformação para ambos os indivíduos.

As concepções que envolvem esse relacionamento, proposto por Watson nos caritas process, podem ajudar os enfermeiros a explorarem melhor os encontros com as famílias, a partir de uma consciência integrada de suas ações para promover momentos de cuidado. Por isso, buscamos na teoria de Watson $(1979,2008)$, os principais conceitos do relacionamento de ajuda e confiança, para podermos contextualizar as reflexões com os enfermeiros, a partir de uma concepção fenomenológica existencial, acerca dos significados pessoais para cuidar integralmente de crianças e famílias.

A partir disso, tomamos o quarto processo: desenvolvimento de uma autêntica relação de cuidado, de ajuda e confiança, como elemento central deste estudo, para focar nas interações entre o profissional e a família. 
Desta forma, acreditamos oferecer subsídios concretos para facilitar os momentos iniciais do encontro dos enfermeiros com as famílias, superando dificuldades encontradas por esses profissionais nos momentos de interação.

Pai e Lautert (2005) apontam para o relacionamento de ajuda e confiança como um importante elemento que oferece subsídios para quebrar as barreiras do relacionamento, reforçando a necessidade de uma comunicação efetiva. Desta forma, vemos que o quarto carative factors e o correspondente clinical caritas processes da Teoria do Cuidado Humano é especialmente relevante para o processo do cuidar em enfermagem porque diminui a distancia entre duas vertentes tão intimamente relacionadas: o cuidado humano e a interação humana, enquanto processos contínuos e em constante (re) construção. Embora este processo seja a ênfase deste estudo, os demais fatores e processos da teoria de Watson também são considerados, pelo fato de abordarem conceitos importantes para o cuidado, e também por possuírem uma estreita relação entre si, integrando elementos concretos para os enfermeiros refletirem sobre seus relacionamentos com famílias de crianças.

Os cinco primeiros processos, de acordo com Watson (2008), podem ser de muitas formas combinados e relacionados. Todos eles, cada um de uma forma diferente, correspondem à linguagem ontológica do desenvolvimento do self do enfermeiro para sustentar-se nas perspectivas do caring-healing, um processo de cuidado que permite a transformação física e espiritual dos seres envolvidos na relação por ocasião do cuidado, permitindo o exercício, do que Watson denomina como caritas nursing (Watson, 2008). Os demais processos, do sexto ao décimo, complementam este fenômeno com uma perspectiva integrada do processo de cuidado e das necessidades humanas, sendo portanto, fundamentais para refletirmos sobre o desenvolvimento da relação de ajuda e confiança no cuidado.

1.4.1 Relacionamento de ajuda e confiança no cuidado: caritas processes

O desenvolvimento de uma relação de ajuda-confiança depende dos outros três processos anteriores (prática do amor, bondade e equanimidade 
para si e para o outro; estar autenticamente presente, permitir/ sustentar/ respeitar profundamente o sistema de crenças e o mundo subjetivo do self/outro; cultivar suas próprias práticas espirituais, aprofundando a autoconsciência para além do ego), assim como está fortemente relacionado ao próximo processo que o segue (estar presente e apoiar a expressão de sentimentos positivos e negativos, como uma conexão profunda com 0 espírito do ser e do ser que cuida do outro). Para Watson, a ligação entre os processos sempre se fará presente por se tratar de uma abordagem holística do ser humano para entender e estudar o cuidado de enfermagem. Portanto, esses processos estão interligados pelo sentido que estabelecem na construção do cuidado humano. Um enfermeiro desenvolve um sistema de valores humanístico-altruísta, acredita na estimulação da fé e da esperança e cultiva a sensibilidade para si e para os outros, visando à formação de uma relação de ajuda-confiança e assim por diante. Um enfermeiro que se compromete com o cuidado é aquele que busca olhar para as necessidades e para os problemas individualmente, fortalecendo com mais facilidade a confiança, a fé e a esperança no cuidado de enfermagem (Watson, 2008). Assim, àqueles que são cuidados se sentirão mais à vontade para compartilhar seus problemas sentimentais com o enfermeiro que responde com um cuidado genuíno (Watson, 2008).

O desenvolvimento de uma relação de ajuda-confiança é um processo especialmente importante no contexto da teoria porque possui elementos que vão além dos sistemas de valores e das bases e fundamentos filosóficos, que são fortes nos três primeiros processos propostos na teoria de Watson. Sustentado por esse arcabouço teórico, a relação de ajuda-confiança inclui elementos de base científica - empírica, como uma lógica palpável para a ciência do cuidado. Watson (2008) argumenta existir uma tendência empírica crescente que apoia a crença de muitas pessoas há séculos: que a qualidade de um relacionamento com outra pessoa é o elemento mais significativo para determinar uma ajuda eficaz. Os três primeiros processos da Teoria do Cuidado Humano referemse à essa qualidade da relação. Entretanto, o relacionamento em si merece atenção e estudo, pois envolve características que interferem na construção 
e consolidação dessa dinâmica, evidenciando aspectos que se mostram como inibidores para o desenvolvimento do cuidado dos enfermeiros com as famílias (Bousso, 2006; Silva, 2010).

\subsubsection{Relacionamento de cuidado transpessoal}

Para Watson (2008), na enfermagem são comuns falhas na compreensão, falta de sensibilidade e habilidade para conectar-se com 0 outro. O problema envolve uma carência na consciência de como a presença de uma pessoa voltada para outra, pode afetar na natureza e na consolidação de um relacionamento, seja o outro um colega, um paciente ou mesmo um familiar. Um paciente que sente o profissional realmente comprometido estabelecerá com mais facilidade confiança, fé e esperança na relação de cuidado, refletindo na saúde, como consequência. Este processo faz parte do que Watson denomina como caritas consciosness, em que ser autêntico e genuíno em um relacionamento é tão fundamental quanto ser ético, possibilitando a abertura do self de um para o outro no reconhecimento da integridade do profissional. Este é o ingrediente fundamental para o verdadeiro encontro de cuidado transpessoal.

Para definir o que Watson chama de relacionamento de cuidado transpessoal, presente na caritas consciousness e parte do quarto caritas processes (CP), a autora contou com influencias e contribuições de outras teorias contemporâneas de enfermagem, como de Newman (1994) e Martha Rogers (1970, 1994). Esse relacionamento baseia-se na visão que cuidado e o amor são níveis mais elevados na consciência do cuidar e torna possível estabelecer conexões entre a cura e o todo, transcendendo os efeitos da cura na doença, simplesmente. Sendo assim, o relacionamento transpessoal convida o profissional a sentir a presença do outro com bondade e tranquilidade, compreendendo que o cuidado é significativo pelo potencial de se tornar um momento marcante na vida tanto do ser cuidado e sua família, quanto dos enfermeiros. Esta autêntica ligação está além do ego profissional e, portanto, os enfermeiros estarão mais sensíveis aos acontecimentos e mais hábeis para enxergar as entrelinhas do sofrimento do outro e da sua família (Watson, 2008). 
A seguir, encontra-se o quadro 2 com as principais concepções do relacionamento transpessoal, a partir da caritas consciousness, como integrante dos fundamentos para o desenvolvimento de um relacionamento de ajuda e confiança no cuidado.

Quadro 2 - Concepções de um enfermeiro caritas: Relacionamento transpessoal - Caritas Consciousness

\section{Concepções de um enfermeiro caritas: relacionamento transpessoal.}

- um enfermeiro caritas tem o comprometimento moral com a sociedade e a humanidade. Ele é capaz de manifestar a intencionalidade e a caritas consciosness em relação a ele e ao outro para proteger, melhorar, promover e preservar a dignidade humana em sua totalidade.

- um enfermeiro caritas aceita o significado subjetivo espiritual dele e do outro enquanto procura preservar o cuidado no meio aos desesperos e ameaças sejam elas biológicas, institucionais ou outras.

- um enfermeiro caritas respeita um relacionamento entre eu e o ser/pessoa e não entre o eu e algo/ coisa.

- um enfermeiro caritas procura reconhecer, respeitar e detectar o espírito do outro através da presença genuína, centrada no Ser naquele determinado momento.

- por meio de ações, palavras, presença não verbal, pensamentos, sentimentos e do uso completo do ser, um enfermeiro caritas se conecta com o outro.

- uma conexão caritas ocorre através de atos autênticos, movimentos, gestos, expressões faciais, procedimentos, informação dada, toque, voz, tom de voz, toque, expressões verbais e ou técnicas científicas de comunicação para cuidar do outro. Todas essas formas de comunicação pessoal e profissional contribuem para a conexão em um cuidado transpessoal.

- um enfermeiro caritas não estabelece um cuidado transpessoal e um momento de cuidado com todo paciente, mas a caritas conciousness é seguida como um ideal para guiar o comprometimento ético-moral e a intencionalidade com cada paciente para sustentar a missão de cuidar da sociedade.

Fonte: Watson, J (2008).

\subsubsection{Momento de cuidado}

O momento de cuidado é um elemento central da teoria transpessoal e da caritas consciousness. Trata-se do momento presente, do agora criado pela situação do cuidar e que se torna parte da experiência individual futura de cada ser. Esse momento utiliza toda forma de conhecimento e recurso para favorecer a interação além do físico, da personalidade, das situações 
de doença, diagnóstico e tratamento. O cuidado é um momento (ponto focal no tempo e no espaço) quando há o encontro do enfermeiro com o paciente, por meio das interações humanas criadas por ocasião do cuidado (Cara, 2003; Watson, 2008). Watson (1999) considera os dois seres - ser cuidado e cuidador - como passíveis de análise e transformação do self no momento de cuidado. Essas duas unidades são campos fenomenológicos distintos e únicos que se unem por interação e, portanto, ambos podem se influenciar por esse momento a partir do aspecto diferencial de cada interação estabelecida. O momento de cuidado se torna de fato transpessoal quando "ele permite a presença de ambos os espíritos - a partir daí o evento do momento expande os limites da abertura entre um e outro e tem a habilidade de expandir também as capacidades humanas" (Watson, 1999: 116-117).

Em 1979, ao descrever o desenvolvimento da relação de ajudaconfiança, Watson reforçou a importância dos enfermeiros interiorizarem algumas atitudes para estabelecer esse relacionamento, como aquelas mencionadas nos outros processos da teoria, ter sensibilidade, estar aberto aos outros e altruísmo, por exemplo. As outras atitudes foram tratadas empiricamente e validadas para incluir também como base da relação de ajuda-confiança. São elas: a congruência, a empatia e a aceitação positiva incondicional (Watson, 1979). Todos esses conceitos foram trazidos por Watson da teoria de Carl Rogers, em que já haviam sido definidos (Rogers, 1974).

\subsubsection{Congruência}

A congruência ou autenticidade foi um termo desenvolvido por Carl Rogers e depois pesquisado e validado empiricamente. Este conceito implica um relacionamento verdadeiro, em que o enfermeiro mostre o que realmente é - "genuíno e sem máscara ou armaduras". Ser genuíno significa ser sincero, honesto e autêntico. Para Watson, este significado se aproxima da congruência e precisam ser desenvolvidos para estabelecer uma relação de ajuda-confiança (Watson, 2008).

Embora essa "transparência" em um relacionamento demande autoconhecimento e muita sensibilidade, ninguém é completamente 
consciente de suas impressões e sensações interiores. Porém, quanto mais sensível alguém for com os sentimentos de outros, sem julgamentos e mais aberto estiver para aceitá-los, maior será o nível de congruência que essa pessoa desenvolve. Alguns sentimentos devem ser controlados e monitorados. É inapropriado e desonesto, principalmente em uma relação de cuidado, revelar os sentimentos impulsivamente. Por isso, os enfermeiros devem aceitar a difícil tarefa de se tornar familiar com as experiências do self e as maneiras como essas podem se manifestar. Os sentimentos, ancorados no subconsciente, que um indivíduo tenta esconder tem um maior potencial de manifestar-se de forma destrutiva na relação com o outro, mesmo que suas reações não sejam intencionais, afetando diretamente a qualidade do cuidado.

"O agir genuíno e congruente é a base para uma relação de ajuda-confiança. $O$ enfermeiro que tem congruência pode ir ao encontro de um cuidado produtivo, porque tem a verdade que transcende a rigidez das expectativas da função"' (Watson 1979: 28)

\subsubsection{Empatia}

A empatia é definida por Watson como "a habilidade do enfermeiro para experenciar o universo privativo e sentimentos do outro, e comunicar a outra pessoa algum grau significativo de compreensão" (Watson, 1979: 28). O enfermeiro que desenvolve o cuidado com genuína intencionalidade possibilita a conexão com o paciente por meio da empatia, e assim, as prioridades e importâncias traçadas no cuidado tornam-se comuns entre enfermeiro e paciente (Watson, 2008). A habilidade de sentir o sentimento do outro, faz com que o profissional e o paciente tenham um ponto de referência comum de uma experiência emocional. Watson ainda considera que ninguém é capaz de passar completamente pela experiência do outro, mas todos já sentiram dor, raiva, tristeza, culpa ou prazer alguma vez, e isso embasa uma referência para desenvolver sensibilidade, respeito e estima para considerar os sentimentos dos outros (Patton et al., 2002) 


\subsubsection{Aceitação positiva incondicional}

Este termo está relacionado à aceitação positiva e incondicional do outro, valorizando o indivíduo como um todo, ao invés de impor condições, sem julgar e avaliar os sentimentos de outras pessoas. Rogers descreveu o termo nonpossessive warmth relacionado à aceitação positiva, como "um sentimento que não é paternalista/maternalista, nem sentimental ou superficialmente social e aceitável." (Watson 1979: 32). É através da aceitação positiva incondicional que o enfermeiro transmite o cuidado ao paciente. Watson diz que, sendo a enfermagem a ciência do cuidado, esta é uma condição necessária para o profissional ter resultados efetivos. Essa aceitação é a expressão do cuidado e, portanto, pode ser comunicado com pequenos detalhes verbais ou não verbais, como um sorriso, gestos, tom de voz, capacidade de ouvir e toque carinhoso (Watson 1979).

Alguns atributos não verbais são descritos por Watson como exemplos da expressão da aceitação positiva incondicional (Watson, 1979: 32-33).

1. manter o contato visual na maior parte da interação,

2. usar tom de voz moderado,

3. ficar relaxado e a vontade consigo mesmo,

4. estar de frente para outra pessoa,

5. ter uma postura aberta,

6. inclinar-se para a outra pessoa,

7. ter uma expressão fácil congruente com o estado emocional do outro.

Em uma relação de ajuda-confiança entre enfermeiro e cliente, alguns aspectos da comunicação precisam ser considerados. Para Watson (2008), o enfermeiro que deseja se comunicar efetivamente dentro de um contexto de ajuda deve responder claramente a todos os tipos de comportamento que uma pessoa expressa na interação com outro, e por isso, esses aspectos são tão importantes em um relacionamento de ajuda-confiança. Ao olhar para o ser cuidado como um ser em interação, o enfermeiro passará a compreendê-lo, enquanto forma de manifestação, e um olhar apropriado para interpretar o outro ou transmitir adequadamente os próprios sentimentos são artifícios necessários para um cuidar efetivo. 
Os profissionais da saúde devem, portanto, compreender cada significado da mensagem transmitida pelo outro, como instrumento importante no plano de cuidado, em direção coerente com a real necessidade do indivíduo. Para isso, existem aspectos relevantes da transmissão não verbal na comunicação e este dado não deve ser subestimado na relação de ajuda-confiança, uma vez que a compreensão de mensagens, significados e sentimentos é fundamental para que a interação se estabeleça de forma autêntica e transpessoal na ocasião de cuidado. Desta forma, o enfermeiro deve reconhecer e valorizar todas as expressões advindas do não verbal como transmissão mais confiável dos reais sentimentos, do que aquilo que é verbalmente expresso (Watson, 1979).

Elementos da comunicação interpessoal são interessantes no desenvolvimento da relação de ajuda-confiança, a partir na correspondência direta que ambos têm com a qualidade de um relacionamento, principalmente, quando se fala em cuidado.

Outro elemento importante ao considerar a comunicação como uma ferramenta terapêutica para promover o cuidado é ouvir, como um elemento essencial desde a primeira interação entre duas pessoas. Ouvir inclui transmissões não verbais como gestos e posturas, que sejam congruentes à mensagem transmitida pelo paciente (Watson, 2008). Tão essencial como as expressões transmitidas ao indivíduo que está falando, é a qualidade e intenção da escuta. Mostrar interesse naquilo que ouve e demonstrar vontade para saber mais daquele conteúdo é uma base para estabelecer confiança. Além disso, o enfermeiro deve aproveitar esse momento para auxiliar e facilitar na compreensão do outro e guiar uma atitude construtiva para um atendimento individualizado. Para isso, é necessário inibir qualquer forma de julgamento, resistir à distrações e aos obstáculos que interferem diretamente na comunicação. (Watson, 2008).

A teoria de Jean Watson nos leva a pensar na existência do ser, no amor como manifestação de cuidado que transcende o aspecto físico do cuidado. Para que os dez elementos que compõem o processo clinical caritas da teoria, façam efetivamente parte da prática do enfermeiro, este precisa se arriscar a realizar uma análise, uma transformação também em 
seu próprio íntimo, para que realmente seja possível a promoção do cuidado humanístico. Encarando como central a questão da qualidade no relacionamento por ocasião do cuidado, nessa perspectiva holística dos fenômenos humanos, a comunicação é fundamental para garantir aspectos importantes na qualidade das interações. Entretanto, é importante ressaltar que o relacionamento de acordo com a Caritas Consciosness, acontece de forma autêntica e genuína e isto serve de base também na comunicação interpessoal para um agir além da técnica, garantindo ferramentas que possibilitem planejar a assistência em suas reais necessidades, além daquelas que são evidentes por conta da situação de doença e sofrimento da família. 


\subsection{UTILIZAÇÃO DA TEORIA DO CUIDADO HUMANO}

A Teoria do Cuidado Humano de Watson vem sendo aplicada em vários contextos, inserida na prática da enfermagem ou considerada referencial teórico para análise de dados. Com ênfase nos estudos que trazem alguma forma de aplicação prática do referencial, trago algumas considerações sobre a literatura mais atual que aborda essa temática.

No Brasil, há uma concentração maior de trabalhos baseados na teoria de Watson na região sul do país. Fato este justificado por Favero et al. (2009), em um trabalho de revisão bibliográfica sobre a aplicação da teoria de Watson no Brasil, pelo foco dado para a área de filosofia de enfermagem, do Programa de Pós-Graduação da Universidade Federal de Santa Catarina. Além disso, atribuiu também o fato de Jean Watson ter visitado algumas vezes o estado e colaborado com docentes e discentes nas pesquisas com esse referencial teórico.

Um grande número de estudos com a Teoria do Cuidado Humano vem sendo publicado nos Estados Unidos, embora autores apontem para o fato de a teoria de enfermagem ainda se configurar como algo não familiar para muitas equipes (Birk, 2007). Apesar disso, os EUA contam com algumas instituições e programas que contribuem para o avanço de pesquisas nessa área. O Watson Caring Science Institute (WCSI), criado em 2007 em Denver (CO) por Jean Watson, é uma organização sem fins lucrativos que visa aprofundar os conhecimentos da filosofia, teoria e prática do cuidado de enfermagem, por meio da ampliação de contatos com esses profissionais na assistência e nas academias ao redor do mundo. Dessa forma, o Instituto pretende traduzir o modelo de cuidado caritas em serviços e programas sistematizados que contribuam para o cuidado em saúde.

Além desse, outros trabalhos que descrevem a utilização da teoria na prática vieram de iniciativas, como a American Nurses Credentialing Center (ANCC), que promove a designação de Magnet, como uma padronização para serviços que utilizam referenciais teóricos e articulam filosofia às atividades diárias da enfermagem. $\mathrm{O}$ Magnet Recognition Program tem o 
intuito de encorajar a utilização de teorias para guiar a prática das instituições, que devem articular o próprio modelo de cuidado a um referencial teórico. Também estimula que as enfermeiras dessas instituições procurem desempenhar atividades de pós-graduação, como mestrado, para garantir um contato mais aprofundado com os referenciais. .Esse indicador tem o objetivo de ampliar forças dentro das instituições de saúde, visando a um cuidado de enfermagem de excelência (Birk, 2007; ANCC, 2005; Clarke, Watson, Brewer, 2009)

Estudos que utilizam a teoria de Watson na prática transitam por diversas áreas como a oncologia (Souza e Lacerda, 2000); unidades de terapia intensiva e de emergência (Paganini, 2000; Pai, Lautert, 2005; Nascimento, Erdmann, 2006); atendimentos domiciliares em situações de transtorno mentais e alcoolismo (Stamm, 2000; Fonseca, Lacerda, Maftum, 2006); pacientes com hipertensão arterial (Erci et al., 2003); crianças e famílias (Bordin, 2000). Além disso, principalmente os trabalhos norteamericanos apresentam práticas implementadas com a equipe de enfermagem como referencial teórico para o cuidado na instituição e não apenas de alguma unidade ou área específica (Watson, Foster, 2003; Sessanna, 2003). A teoria de Watson vem sendo aplicada no cuidado de enfermeiros em diferentes especialidades, incluindo alguns deles um olhar também com famílias, dentro de algum contexto específico (Stamm, 2000; Fonseca, Lacerda, Maftum, 2006; Souza, Lacerda, 2000; Bordin, 2000).

O relacionamento de ajuda e confiança da teoria de Watson ganha destaque em alguns estudos que o associam com mais facilidade aos eventos e situações em que enfermeiros acreditavam prestar um cuidado diferenciado por reforçar valores humanos fundamentais em suas ações. Entre as principais situações em que os enfermeiros acreditam ter prestado um cuidado autêntico e voltado às necessidades do paciente como um ser mente-corpo-espírito, encontram-se questões relacionadas à intencionalidade dos gestos de cuidado para ajudar o outro ao segurar as mãos ou reconhecer as emoções dos pacientes (Gallagher-Lepak, Kubsch, 2009). Essas emoções são reconhecidas à medida que o enfermeiro trabalha sua sensibilidade, por meio da qualidade do contato visual e da 
importância de estimular a expressão do que os pacientes sentem ou pensam, para quebrar "barreiras" no relacionamento. Destaca-se nesse momento a comunicação de forma eficaz, como fundamental para estabelecer o relacionamento de ajuda-confiança (Pai, Lautert, 2005). O desenvolvimento da relação de ajuda e confiança foi reconhecido por enfermeiros e líderes de equipe como uma referência importante para a interação com o paciente e sua família, a partir do cultivo de uma consciência para o cuidado, que permite atendimento integral no processo de ajuda nas relações de saúde. Ainda ressaltam que desenvolver essa relação requer tempo, intenção e paciência (Caruso, Cisar, Pipe, 2008; Pipe, 2008).

Ainda sobre o desenvolvimento da relação de ajuda e confiança, um estudo que utilizou os carative factors em unidades de emergência ressaltou este como um fator importante para a interação dos participantes do processo de cuidar e estratégia fundamental no contexto em que os indivíduos e familiares vivenciam situações inesperadas e traumáticas. Destaca-se a questão do tempo curto de contato entre profissionais e clientes numa unidade de emergência como um possível elemento desencorajador à equipe para o desenvolvimento da relação de ajuda e confiança; porém a experiência vivida revela que, ao expressar humanidade na interação com o outro, esse relacionamento pode ser atingido independentemente do tempo do cuidado e formação do vinculo. Além disso, reforça a comunicação como ferramenta fundamental para ser honesto no relacionamento e enfrentar as dificuldades de se colocar no lugar do outro (Silva et al., 2002).

Aspectos da teoria de Watson são utilizados também na relação de líderes com a equipe de enfermagem. Nesse caso, destacou-se a importância da confiança nessa relação para compartilharem problemas e informações que reflitam no cuidado prestado. Um enfermeiro sente-se muito mais à vontade de dividir uma idéia quando há um alto nível de confiança e com ela a certeza de que ele será tratado com respeito. Esses sentimentos fazem parte da relação e energia trazida pelo cuidado e, 
quando são internalizados pelas pessoas, influenciam também as relações com a equipe (Pipe, 2008).

Tal influência deve estar presente também no ambiente como forma de estimular a constante utilização desse referencial na prática do cuidado. Um estudo qualitativo e quantitativo demonstrou que os enfermeiros que obtêm um score mais elevado numa escala aplicada com pacientes, cujo conteúdo avalia o cuidado prestado a partir dos caritas processes, podem se sentir mais frustrados quando o ambiente é incongruente com os valores que adotam para o cuidado (Persky, et al., 2008). Ao invés disso, um ambiente pode ser transformado quando se implementa um referencial filosófico para a assistência. A utilização da Teoria do Cuidado Humano em um hospital nos EUA garantiu uma mesma linguagem para o cuidado entre todos da equipe, proporcionando um ambiente mais nobre e consequentemente atraindo aqueles que compartilham das mesmas ideias e valores para se adequar à instituição (Birk, 2007).

O cuidado transpessoal é apresentado como alternativa e proposta para uma assistência baseada em princípios humanos e de igualdade entre os seres envolvidos no cuidado. Um encontro transpessoal pode não ocorrer com todos os pacientes, mas não é impossível que ele se desenvolva em outras situações e momentos (Watson, 2008; Fonseca, Lacerda, Maftum, 2006). Ao utilizar esses pressupostos com pacientes e famílias que vivenciam um transtorno mental, percebeu-se a reconstrução das relações de poder dos profissionais de saúde, pois os aspectos humanos superam os técnicos na interação de profissionais, cliente e família (Fonseca, Lacerda e Maftum, 2006).

Nascimento e Erdmann (2006), em um estudo que relaciona os carative factors com problemas de enfermagem, acrescentam que, quando as interações efetivamente ocorrem de forma transpessoal, elas transgridem a rigidez das técnicas e criam um caminho mais humano, com sensibilidade ao outro e aos sofrimentos envolvidos, independentemente do comportamento expresso e do contexto em que os indivíduos estão inseridos. 
Em uma unidade de emergência Pai e Lautert (2005), argumentaram a importância de considerar, num mesmo patamar, os referenciais teóricos da competência técnico-científica e das relações humanísticas. Ainda assim, no Brasil, há certa dificuldade em conseguir aplicar na prática uma teoria de cuidado, por falta de conhecimento dos conceitos no ambiente de trabalho e na formação profissional. Tanji e Novakoski (2000), apresentaram uma proposta de inserção da Teoria do Cuidado Humano de Watson, trabalhando alguns conceitos em grupos de reflexão entre enfermeiros, para que pudessem construir um marco de referência que se aproximasse das situações por eles vivenciadas.

Outra proposta de aplicação da teoria inseriu, no sistema eletrônico de enfermagem em um hospital nos EUA, uma nova linguagem compatível com a teoria de Watson para documentar intervenções possíveis a partir dos dez carative factors. Além disso, foram realizados treinamentos e discussões com equipe sobre o novo referencial para garantir a implementação. Esse estudo traz como proposta de cuidado a utilização de prescrições e diagnósticos baseados na teoria, advindo de uma padronização na linguagem, que inclua aspectos humanos e subjetivos dos pacientes (Rosenberg, 2006).

A Teoria do Cuidado Humano ainda pode ser considerada como uma estratégia que trabalha com a consciência do cuidado e desenvolve uma alta sensibilidade para reconhecer os indivíduos pela sua unicidade. Para isso, ouvir atentamente é fundamental na relação de cuidado, não apenas como estratégia terapêutica, mas também para reconhecer o que é significativo aos pacientes em diversas situações e como a experiência atual e outras vividas podem influenciar na qualidade de vida e na paz do corpo, da mente e do espírito. Os enfermeiros demonstram, desta forma, não apenas preocupação com o sofrimento dos indivíduos e famílias, como influencia na transformação das trajetórias de vida dos envolvidos no momento do cuidado (Bernick, 2004).

Erci et al. (2003), ao trabalhar com a autonomia e a noção de responsabilidade pela própria saúde, demonstrou, a partir da teoria de Watson, que esse relacionamento de cuidado interfere na qualidade de vida 
de pacientes com hipertensão arterial, garantindo melhores resultados na prevenção de complicações. Esse estudo trouxe uma proposta de intervenção para a atenção primária, a partir da utilização da teoria de Watson.

Sessana (2003) apresentou uma experiência feita com préadolescentes entre 7 e 12 anos de idade em unidades de saúde, para educá-los sobre a promoção da saúde de forma holística, com base no referencial de Watson. Essas atividades, realizadas em grupo, trabalhavam conceitos sobre vida, ser humano, saúde, holismo, espiritualidade e cuidado, revelando que esses jovens são capazes de compreender o indivíduo como um ser de necessidades não só físicas, mas também, mentais, emocionais e espirituais. Para a autora, a forma trabalhada com os jovens é uma, das diversas estratégias de ensino-aprendizagem que ajudam crianças e adolescentes a expressarem os sentimentos sobre sua saúde, envolvendo até, conceitos mais abstratos, que os auxiliam a advogar pelo próprio processo de saúde, assim como, favorece a compreensão dos enfermeiros sobre as necessidades desse grupo.

Um modelo de cuidado e atendimento de enfermagem baseado na Teoria do Cuidado Humano de Watson foi implementado em um hospital pediátrico nos EUA para integrá-la com terapias avançadas em dor de crianças. As enfermeiras que participaram desse projeto tiveram a oportunidade de perceber como as diretrizes teóricas podem aprimorar a consciência do cuidado, trabalhando a autonomia e a abordagem interdisciplinar para diminuir o sofrimento das crianças (Watson, Foster, 2003).

Outros estudos brasileiros incluem a utilização da teoria de Watson na abordagem com famílias e crianças. Como proposta, um deles desenvolveu um modelo para assistência de enfermeiros que cuidavam de bebês e famílias em sala de vacina, a partir dos seis primeiros fatores da teoria de Watson. Bordin (2000), justificou essa escolha pelo fato dos quatro últimos fatores possuírem um alto grau de subjetividade e por isso seriam difíceis de trabalhar com crianças na faixa etária de 0 a 15 meses. Nesse contexto, foram observadas e documentadas atitudes de cuidado consonantes com a 
teoria, trazendo reflexões sobre a importância da organização dos serviços, do relacionamento entre profissionais e da necessidade de estabelecer um cuidado diferenciado em salas de vacina, ambiente rico para avaliar a relação e a saúde dos bebês e familiares (Bordin, 2000).

Em outro estudo envolvendo família, Stamm (2000) desenvolveu uma proposta de cuidado com visitas domiciliares, de acordo com os três primeiros fatores da teoria de Watson, em duas famílias que vivenciavam a situação de alcoolismo. Destacou-se a necessidade de ser autorizado a participar e entrar no ambiente da família, sendo esse um fator determinante para a qualidade dos relacionamentos entre enfermeiros e familiares no atendimento domiciliar. Ao mesmo tempo, lidar com famílias inclui diversas outras dificuldades e obstáculos. Esses desafios podem ser trabalhados à medida que se consegue estabelecer um cuidado humano e autêntico, centrado em valores fundamentais, que estimule a fé, a esperança no tratamento e na superação da atual condição, por meio de gestos e palavras que demonstrem sensibilidade a todas essas questões (Stamm, 2000).

Em outro estudo brasileiro realizado com famílias que conviviam com parentes com câncer, foram relatadas experiências de cuidado considerando o encontro transpessoal, a partir das fases do processo de cuidar, propostas por Lacerda (1997): contato inicial, aproximação, encontro transpessoal e separação. Esse processo reforçou a importância do cuidado domiciliar e transpessoal no contato do enfermeiro com a família, para aproximação e desconstrução do "anonimato do uniforme branco". Além disso, a família sente-se mais protegida e valorizada nesse modelo de assistência. Assim um enfermeiro consegue compartilhar com ela, melhores condições e ferramentas para garantir qualidade de vida (Souza e Lacerda, 2000).

Percebe-se que, na concretização do cuidado tendo como referencial a teoria de Watson, fazem-se presentes reflexões que visam conhecer verdadeiramente o outro e a si mesmo. Os estudos, de uma forma geral, buscam uma proposta humanística e utilizam a teoria como possibilidade de garantir essa perspectiva, valorizando o encontro dos sujeitos como potências transformadoras da realidade subjetiva. 
Um estudo visou à construção de um marco de referência utilizando a teoria de Watson, a partir de um "processo reflexivo grupal" com enfermeiros em uma unidade crítica. Os resultados mostraram que tornar o cuidado mais holístico e centralizado nos universos subjetivos dos sujeitos, envolve, não apenas, a valorização do cuidar, mas também, a necessidade de uma atenção voltada à qualidade da interação entre seres cuidados e cuidadores, com influência do ambiente e do conhecimento científico (Paganini, 2000).

Vimos, que os estudos que utilizam, na prática, a Teoria do Cuidado Humano visam construir uma referência para o cuidado de enfermagem, a partir de uma visão mais humana desse processo. Diversas formas de implementação foram descritas, por treinamentos com a equipe de enfermagem para aplicação dos conceitos, relato de experiência ou observação de pacientes e famílias durante a introdução desse referencial. Poucos foram os estudos controlados, apesar da necessidade de mais estudos desse tipo para a ciência do cuidado (Watson, 2008).

Diante do exposto, considerando o processo quarto da teoria de Watson - desenvolvimento de uma relação de ajuda e confiança no cuidado - esses estudos nos levam às seguintes questões: De que maneira a teoria de Jean Watson pode ajudar os enfermeiros na abordagem relativa ao desenvolvimento da relação de ajuda e confiança com famílias de crianças? Quais são os fatores envolvidos na interação do enfermeiro com as famílias de crianças, de acordo com o mesmo referencial?

A proximidade dos elementos teóricos que compõem 0 relacionamento de ajuda-confiança com a prática do cuidado de enfermagem foi fundamental na escolha da teoria para nortear o estudo. As evidências empíricas que um referencial traz para o cuidado de enfermagem devem ser seriamente consideradas por esses profissionais na construção de uma assistência mais humana e integrada para lidar com o sofrimento de famílias que vivenciam uma situação de doença (Watson, 2008). O potencial que uma teoria tem para transformar a relação de cuidado e promover crescimento pessoal para facilitar o processo saúde-doença depende se essa teoria é adequadamente reconhecida, desenvolvida e utilizada por enfermeiros (Watson, 2009). 


\section{OBJETIVOS}

\section{OBJETIVO GERAL}

Compreender a experiência dos enfermeiros sobre o desenvolvimento da relação de ajuda e confiança com famílias de crianças em unidades de pediatria, à luz da Teoria do Cuidado Humano de Jean Watson.

\section{OBJETIVOS ESPECÍFICOS}

Identificar o significado que os enfermeiros atribuem à experiência de vivenciar a relação de ajuda e confiança no cuidado das famílias de crianças.

Conhecer as dificuldades e facilidades dos enfermeiros no desenvolvimento da relação de ajuda e confiança com as famílias de crianças internadas. 


\section{ASPECTOS METODOLÓGICOS}

\subsection{TIPO DE ESTUDO}

Foi utilizada a abordagem qualitativa para realização do estudo. Ela permite a investigação de fatos e fenômenos de acordo com a realidade da própria pessoa em um determinado contexto, por meio da interpretação do pesquisador com base na observação de fenômenos e nas linguagens faladas ou escritas dos sujeitos (Bodgan e Biklen, 1994). Para Creswell (2007), a pesquisa qualitativa para compreender um fenômeno baseia-se em diferentes referenciais metodológicos investigativos, que permitam explorar um problema social ou humano de acordo com o ponto de vista dos sujeitos. A pesquisa qualitativa tem, também, a capacidade de:

\footnotetext{
Incorporar a questão do significado e da intencionalidade como inerentes aos atos, às relações e às estruturas sociais, sendo estas últimas tomadas tanto no seu advento quanto na sua transformação, como construções humanas significativas. (Minayo, 2008, p.10).
}

Este estudo utilizou a abordagem qualitativa descritiva (Sandelowski, 2010) para melhor compreender a experiência dos enfermeiros sobre 0 desenvolvimento da relação de ajuda e confiança com famílias de crianças internadas. A pesquisa descritiva, como um método independente, permite desvelar de forma abrangente a experiência humana em um determinado contexto social. O objetivo é ficar perto da superfície dos dados durante a captura dos elementos da experiência e o rigor científico inerente é um reflexo da capacidade de um pesquisador para alcançar esse objetivo. Essa modalidade permite certo grau de interpretação (Sandelowski, 2010) e as descrições vão depender, portanto, das percepções, inclinações e da sensibilidade do pesquisador (Milne, Oberle, 2005).

Como referencial teórico foram utilizados os pressupostos da Teoria do Cuidado Humano de Jean Watson. Essa teoria está centrada nos conceitos humanísticos do cuidado, olhando para o individuo nas dimensões 
biopsicológica, espiritual e sociocultural e fundamenta-se em pressupostos fenomenológicos existenciais (Watson, 2008).

\subsection{TRATAMENTO E ANÁLISE DOS DADOS}

A análise dos dados foi pautada na análise temática, que envolve a procura por temas que apresentem uma considerável importância para descrever um determinado fenômeno. Identificar um tema pressupõe a leitura e releitura cuidadosa dos dados, reconhecendo as similaridades que permitem configurar uma categoria de análise (Fereday, Muir-Cochrane, 2006).

Neste estudo, foi escolhido o modelo híbrido de análise temática, descrito por Fereday e Muir-Cochrane (2006), que incorpora tanto a abordagem dedutiva baseada em modelos de códigos previamente determinados, proposta por Crabtree e Miller (1999), quanto a abordagem indutiva de Boyatzis (1998), guiada pelos dados.

A escolha do modelo híbrido de análise temática para este estudo permite complementar os pressupostos do referencial teórico adotado, integrando-o ao processo de análise dedutiva, com a possibilidade de identificar temas relacionados aos dados, por meio da codificação indutiva. O modelo híbrido de análise temática tem sido utilizado e recomendado dentro da pesquisa em enfermagem (Fereday, Muir-Cochrane, 2006).

O processo de codificação dos dados permite que sejam identificados e decodificados, ou seja, possibilita perceber a importância desses dados e o potencial de significados para a análise, previamente ao processo de interpretação (Boyatzis, 1998). Para Boyatzis (1998), um bom código permite assimilar a riqueza qualitativa do fenômeno e é definido como um "[...] padrão na informação que, no mínimo, descreve e organiza as possíveis observações e, no máximo, interpreta aspectos do fenômeno de estudo".

Para essa modalidade de análise, inicialmente, deve-se desenvolver um template, ou seja, um modelo de códigos, aplicado com o intuito de organizar o texto para interpretações posteriores (Crabtree, Miller, 1999). Esse processo é anterior ao início da análise dos dados. O template serve 
como ferramenta de gerenciamento dos dados, ao organizar fragmentos do texto que possuam similaridades, auxiliando na interpretação posterior do material colhido (Crabtree, Miller, 1999).

Esse template pode ser construído por meio de uma leitura preliminar do texto a ser analisado, mas também pode ser desenvolvido a partir do referencial teórico da pesquisa, como foi feito para este estudo. Sendo assim, organizamos o template com base nos 10 carative factors e clinical caritas processes, da Teoria do Cuidado Humano de Jean Watson (Watson, 2008). Reforçamos que, apesar de utilizarmos o desenvolvimento da relação de ajuda e confiança presente no quarto processo da teoria de Watson, como objeto central do estudo, os demais carative factor e caritas processes, como vimos anteriormente, possuem uma inter-relação importante que deve ser considerada ao pensarmos na complexidade dos processos que envolvem a interação de cuidado. Todas as dimensões que compõem os processos da teoria representam a filosofia, a ética e uma referência para sustentar as relações de cuidado, pautadas em valores humanos (Watson, 2008). Por serem, então, parte integrante de um mesmo fenômeno, o cuidado, não poderíamos desconsiderar os demais processos na análise dos dados.

A etapa para a elaboração do template envolveu a síntese, a codificação dos dados e a definição de temas iniciais. Para tanto, foi feita uma leitura exaustiva e a síntese dos dados brutos, esboçando pontoschave destacados pelos participantes em resposta às perguntas das entrevistas (Fereday, Muir-Cochrane, 2006).

A partir daí, utilizando a técnica analítica, o template foi aplicado com o propósito de identificar unidades de texto significativas na análise dedutiva (Crabtree, Miller, 1999). Nesse momento, a análise dos dados foi guiada, mas não restrita, pelo template. Durante a codificação inicial das transcrições, códigos indutivos emergiram relacionados a fragmentos de dados que descrevam um novo tema observado no texto (Boyatzis, 1998). Nesse estágio, o texto é codificado por meio da combinação dos códigos do template com tais fragmentos de dados, selecionados como representativos, 
podendo ocasionar não só sua expansão, como também a criação de novos temas.

O passo seguinte compreendeu a conexão dos códigos e a identificação dos temas. Conectar os códigos é o processo de descobrir temas e padrões nos dados (Crabtree, Miller, 1999).

A fase final caracterizou-se por um processo avançado de agrupamento dos temas surgidos inicialmente. Aqui, recomenda-se que os estágios anteriores sejam minuciosamente examinados para garantir que os temas agrupados, de fato, representem a análise inicial dos dados e os códigos articulados, caracterizando o que Crabtree e Miller (1999) denominaram de fase de confirmação. A interação entre texto, códigos e temas envolveu várias leituras antes que a análise evoluísse para a fase interpretativa, na qual as unidades são conectadas.

Embora o processo tenha sido apresentado e descrito como linear, a análise temática é um processo interativo e reflexivo. A coleta e a análise dos dados devem ser feitas simultaneamente, e essa interatividade aplicada a todo o processo qualitativo de análise de dados é que confere à pesquisa confiabilidade e rigor metodológico (Fereday, Muir-Cochrane, 2006).

\subsection{PROCEDIMENTO PARA COLETA DADOS}

A coleta dos dados foi realizada em três etapas que serão explicadas a seguir:

1- Apresentação de conteúdo teórico e material de apoio;

2- Vivência do relacionamento de ajuda e confiança;

3- Entrevista individual com os enfermeiros participantes do estudo.

Antes de iniciarmos o trabalho na instituição, realizamos uma reunião com a enfermeira responsável pelas pesquisas do local do estudo. Nesse momento, foram apresentados os objetivos do estudo e as etapas necessárias para a realização da coleta de dados. Explicamos a proposta da oficina que chamamos de "Da teoria para a prática: o cuidado humano e o papel da enfermagem no cuidado centrado na família de crianças hospitalizadas". Acordamos que o convite para a participação na oficina 
seria feito para todas as enfermeiras das unidades pediátricas, bem como para as respectivas encarregadas de cada setor (Apêndice A). A enfermeira responsável se prontificou a agendar a melhor data para a realização da oficina e divulgá-la nas unidades pediátricas.

\section{1- Apresentação de conteúdo teórico e material de apoio}

A primeira etapa foi a realização da oficina "Da teoria para a prática: 0 cuidado humano e o papel da enfermagem no cuidado centrado na família de crianças hospitalizadas", aberta a todos os enfermeiros de unidades pediátricas do hospital em que se realizava a coleta dos dados, independentemente de suas disponibilidades em participar do estudo. A oficina foi realizada em um período de 4 horas no mês de outubro de 2011 , nos dois períodos (manhã e tarde) para alcançar um maior número de participantes, que não pudessem participar em detrimento das escalas de trabalho, e também para não prejudicar o andamento das unidades pela ausência das enfermeiras participantes.

O objetivo principal da oficina foi o de apresentar brevemente 0 cuidado centrado na criança e na família, os elementos do desenvolvimento da relação de ajuda e confiança, contextualizados nos processos caritas da teoria de Watson, e explorando o conceito de dignidade. A dignidade é o elemento central para cuidar de seres humanos, segundo Jean Watson (1979, 2008). Para ela, o cuidado deve ser visto como um ideal moral da enfermagem para preservar a dignidade humana, ajudando o outro a restabelecer a saúde e encontrar significado na doença e no sofrimento.

Como estratégia foi feita uma apresentação expositiva com vídeos e imagens para estimular reflexões sobre a prática do cuidado prestado, bem como despertar a atenção para a maneira como os enfermeiros interagem com as famílias nos contextos de cuidado. O intuito era levantar discussões para que pudéssemos articular os elementos trazidos pelos enfermeiros com o referencial teórico proposto, mais especificamente, com o desenvolvimento do relacionamento de ajuda e confiança no cuidado (Watson, 2008).

Essa oficina foi realizada por mim, aluna de mestrado, e pela orientadora do estudo. Durante a oficina, a orientadora desempenhou o 
papel fundamental de ajudar o grupo no processo de pensar, agir, refletir e avaliar o modo como os enfermeiros promoviam engajamento e desenvolviam os relacionamentos com as famílias de crianças internadas, de acordo com os exemplos trazidos pelos profissionais. Coube a mim a tarefa de apresentar os processos caritas da teoria de Watson e expor o material de apoio que estava sendo oferecido aos enfermeiros com o intuito de aproximar os elementos do relacionamento de ajuda e confiança propostos pela teoria de Watson do cotidiano dos enfermeiros, bem como estimular reflexões acerca da prática do cuidado.

O material de apoio se constituiu de dois instrumentos. Um deles descrevia elementos específicos do relacionamento de ajuda e confiança, adaptado do Watson Caring Science Institute (WCSI, 2010) (Apêndice B); o outro trazia aspectos gerais da Teoria do Cuidado Humano, adaptado também do documento do WCSI e de publicações da Royal College of Nursing (RCN, 2008) sobre a defesa da dignidade (Apêndice C).

Esses instrumentos consistiam principalmente, além da descrição do quarto processo da teoria, de questionamentos para estimular a reflexão, estratégias propostas por Watson para guiar o profissional ao encontro de uma consciência mais clara da presença do humanismo na relação com o self e com o outro (WCSI, 2010; Cara, 2003). As publicações do Watson Caring Science Institute (WCSI, 2010) e da Royal College of Nursing (RCN, 2008) possibilitaram levar a proposta de reflexão aos enfermeiros participantes deste estudo, de uma maneira simples e consistente com o referencial teórico adotado (Apêndice $B$ e $C$ ).

Foram realizados os procedimentos de tradução de instrumentos para adaptá-los à língua portuguesa (Guillemin, Bombardier, Beaton, 1993). O objetivo das etapas foi manter o significado e a intenção do instrumento original, tornando-o compreensível e culturalmente relevante (Ferreira et al., 2010; Sperber, 2004; Beaton et al., 2000).

A parte do documento oficial que se desejava traduzir foi enviada para duas tradutoras fluentes no idioma inglês, língua da versão original. Uma tradução foi feita por um profissional da área de saúde que conhecia os 
objetivos do estudo e outra, por um professor de inglês que não estava a par dos objetivos do estudo (tradução cega), gerando assim duas versões.

Uma comparação das duas versões com o original foi realizada em uma reunião, na qual participaram a pesquisadora e quatro juízes da escola de enfermagem da USP, sendo que duas conheciam a Teoria do Cuidado Humano e duas não conheciam. Todas apresentavam proficiência em língua inglesa. A intenção era chegar ao consenso de um único documento e avaliá-lo quanto às equivalências de itens, conceituais, semânticas e operacionais, bem como a validade de conteúdo.

Com o resultado dessa discussão, foi construída uma versão em português, que passou por um processo chamado de retro-tradução (Back translation). Essa versão foi enviada para dois profissionais, que realizaram a tradução para o idioma de origem (inglês). Os tradutores não tinham conhecimento prévio da temática em estudo. Cada tradutor fez uma versão e a pesquisadora junto com a orientadora realizaram as correções e adequações necessárias, chegando à versão final, apresentada aos enfermeiros.

Os instrumentos foram impressos e entregues a todos os enfermeiros que participaram da oficina, como proposta de uma consulta rápida para estimular a reflexão sobre a relação com o outro e com o self, dentro dos contextos de cuidado (apêndice B e C) Nesse sentido, acreditamos que os materiais ajudaram os enfermeiros a conhecerem melhor os elementos do referencial enquanto realizávamos as discussões e permitiram que voltassem a refletir durante a segunda etapa da coleta dos dados.

Estendeu-se a todos os quinze enfermeiros que estiveram presentes na oficina, o convite para participar do estudo, mediante a assinatura do termo de consentimento livre e esclarecido. Ao final da oficina foi acordado que a pesquisadora voltaria a fazer contato para tomar conhecimento dos enfermeiros que aceitassem fazer parte das etapas seguintes.

2- Vivência do relacionamento de ajuda e confiança

Ao final da oficina, os enfermeiros foram estimulados a repensar constantemente sobre os encontros de cuidado que promoviam com as 
famílias, procurando se engajar com elas e praticar intencionalmente um relacionamento de ajuda e confiança. Reforçamos nessa etapa que, de acordo com Watson (2008), as interações no cuidado de enfermagem são tão intuitivas, criativas, autênticas e pessoais quanto os processos empíricos, relacionados aos conhecimentos técnicos da profissão. Nessa etapa, os enfermeiros poderiam fazer uso dos instrumentos elaborados como material de apoio.

Essa fase compreendeu um período de 30 a 60 dias a contar da realização da oficina. Esse tempo foi estabelecido para que os enfermeiros, nos diferentes campos de atuação, pudessem se engajar e vivenciar as interações com as famílias. Durante essa etapa, a pesquisadora e a orientadora, estiveram disponíveis por email, por telefone ou por meio de reuniões e visitas agendadas previamente para esclarecer quaisquer dúvidas. Mais materiais de consulta, com sugestões de leitura e artigos de revistas nacionais e internacionais foram entregues para os enfermeiros. Após esse período, foi feito contato com os participantes do estudo para o agendamento das entrevistas.

3- Entrevista individual com os enfermeiros participantes do estudo

Nesta etapa, foram realizadas entrevistas semi-estruturadas com os participantes. Elas objetivaram compreender a experiência dos enfermeiros sobre o desenvolvimento da relação de ajuda e confiança com as famílias de crianças em unidades de pediatria, à luz da teoria de Watson. Também buscaram identificar os significados atribuídos nas interações com as famílias, as dificuldades e facilidades experenciadas nesse processo e a viabilidade de o referencial teórico de Watson ser inserido na prática com familiares de crianças.

As entrevistas foram iniciadas com as seguintes perguntas: (1) O que o ajuda a desenvolver um relacionamento com a criança e a família na sua prática? (2) Conte-me sobre sua experiência no engajamento das relações com os familiares. (3) Como acha que você permite desencadear um relacionamento de ajuda e confiança, como propõe a Teoria do Cuidado Humano de Jean Watson? (4) De que maneira você acha que as idéias do 
referencial apresentado na oficina fizeram sentido para a sua prática no relacionamento com as famílias? (5) Quais dificuldades você encontrou para estabelecer um relacionamento de ajuda e confiança com as famílias? (6) Que outro referencial você conhece e faz uso nas suas interações com famílias?

Todas as entrevistas realizaram-se na própria unidade de trabalho dos enfermeiros, conforme escolha dos participantes, em horário agendado e foram digitalmente gravadas.

\subsection{CENÁRIO DA PESQUISA E PARTICIPANTES}

O estudo foi desenvolvido em um hospital geral privado no município de São Paulo. Contou com a participação de enfermeiros do pronto socorro infantil, unidade de tratamento intensivo e semi-intensivo pediátrica e neonatal e unidade de internação pediátrica.

Participaram da pesquisa 12 enfermeiros, sendo que 8 estavam diretamente na assistência e quatro exerciam atividades administrativas. Para compor essa amostra, foram convidados todas os enfermeiros que atendessem aos seguintes critérios de inclusão: ser enfermeiro, atuar no setor de pediatria, participar da oficina e concordar em participar da pesquisa mediante a assinatura do termo de consentimento livre e esclarecido. Embora 15 enfermeiros tenham participado da oficina, três não apresentaram os critérios de inclusão necessários.

Os enfermeiros participantes do estudo eram do sexo feminino tinham entre 1 e 28 anos de formadas, com média de 14 anos - tinham entre 6 meses e 23 anos de trabalho no hospital referido neste estudo, sendo a média de 9 anos. A maioria dos enfermeiros possuem alguma pósgraduação e a maior parte de suas experiências profissionais estão relacionadas à pediatria.

Uma caracterização mais detalhada de cada participante está descrita no quadro 3 : 
Quadro 3 - Caracterização das participantes segundo tempo de formada, de trabalho na instituição do estudo, pós-graduação, experiências anteriores e unidade em que exercem suas atividades.

\begin{tabular}{cccccc}
\hline Enf. & $\begin{array}{c}\text { Tempo de } \\
\text { formação } \\
\text { (anos) }\end{array}$ & $\begin{array}{c}\text { Tempo na } \\
\text { Instituição } \\
\text { (anos) }\end{array}$ & $\begin{array}{c}\text { Pós- } \\
\text { graduação }\end{array}$ & $\begin{array}{c}\text { Unidade em } \\
\text { que trabalha }\end{array}$ & $\begin{array}{c}\text { Experiências } \\
\text { anteriores }\end{array}$ \\
\hline $\mathbf{1}$ & 5 & 1 & Sim & UTI neo & Pediatria e \\
maternidade
\end{tabular}

\subsection{ASPECTOS ÉTICOS}

O projeto foi submetido ao Comitê de Ética em Pesquisa da instituição participante do estudo, conforme Resolução 196/96 do Conselho Nacional de Saúde, recebendo parecer positivo. Posteriormente, as participantes foram convidadas a contribuir com o estudo, sendo assegurado o direito de privacidade e não-identificação dos sujeitos. Os objetivos do estudo foram esclarecidos as participantes mediante leitura do termo de consentimento livre e esclarecido (Apêndice D). Esse termo foi assinado pela participante e pelo responsável pelo estudo, em duas cópias, contendo nome e telefone para contato. Uma das cópias permaneceu com a participante, conforme Resolução 196/96 do Conselho Nacional de Saúde (Brasil, 1996). 


\section{RESULTADOS}

Os resultados das entrevistas foram articulados aos carative factors (1979) e caritas processes (2008), como parte da análise dedutiva dos dados (Crabtree e Miller,1999). Para apresentá-los, uma consideração breve sobre cada um dos processos da teoria foi feita. Desta, forma pretende-se aproximar o referencial teórico do estudo da organização dos dados dos discursos. O tema avaliando a experiência foi identificado, decorrente do estudo indutivo dos dados (Boyatzis,1998), constituindo assim o modelo híbrido de análise temática utilizado neste estudo e proposto por Fereday e Muir-Cochrane (2006).

Iniciando pelo primeiro carative factor (CF)/ caritas processes $(C P)$ da teoria, temos:

1. CF (1979) A formação de um sistema de valores humanísticoaltruísticos;

CP (2008) Prática da gentileza e equanimidade para si e para o outro.

Esse processo explora a prática do amor como forma e expressão de uma consciência para cuidar do outro. Para tanto, o enfermeiro tem que estar aberto ao self, ao outro, ao ambiente e ao universo, envolvido por uma intencionalidade, um propósito nas suas ações de cuidado.

Adquirir consciência e intencionalidade no cuidado torna o profissional capaz de experienciar os dois conceitos importantes e interligados para 0 desenvolvimento da prática que sugere esse primeiro processo da teoria de Watson. Trata-se da equanimidade, um estado interior de equilíbrio e serenidade, que ajuda a diminuir o sofrimento e valorizar os momentos agradáveis, por meio de um alto grau de consciência, levando a oferecer loving-kindness que neste estudo optamos por traduzir como gentileza para o self e para o outro.

Inspirados por esses sentimentos, os enfermeiros empenham-se em preservar a dignidade do ser humano nas relações de cuidado, objetivo fundamental da profissão, segundo Watson (2008). Dentro dessa 
perspectiva, percebemos que eles reconhecem a proximidade entre os valores do profissional e o sistema humanístico para construir um relacionamento de cuidado. Vimos que os enfermeiros mostram a necessidade de exercerem uma assistência que permita a prática da gentileza, da bondade, do carinho e do respeito, independentemente da família ou da criança. São aspectos já incluídos na realidade e na crença de cada profissional, motivo pelo qual puderam se identificar com o referencial trabalhado.

Então eu acho que (o arcabouço teórico) vem fortalecer um sentimento de amor, de cuidado. Achei isso muito forte quando eu li (a teoria). (Enf. 4)

Cuidar é dar atenção, carinho, amor. É compartilhar! (Notas de observação)

O cuidado é o carinho, o respeito e o acolhimento. (Notas de observação)

Para os enfermeiros, estes elementos são evocados com mais facilidade quando se trabalha com criança. A fragilidade desta quando está doente entra em contradição com o processo de viver e morrer do ser humano, o que proporciona instintivamente um empenho maior para lutar pela saúde da criança. Adicionalmente, acreditam que trabalhar com a família também é mais fácil nas unidades pediátricas, pelo envolvimento natural dela e dos profissionais no processo de recuperação desse paciente, além de o contato enfermeiro-família ser mais evidente, pela presença durante a internação da criança.

(...) A humanização, com uma criança, é mais fácil. (...) No inconsciente coletivo, ser humano com uma criança talvez seja mais simples do que ser com um idoso ou um adulto. (Enf. 4)

Como é que você vai lidar com o ser humano e falar que você não se envolve? Uma criança... Você não se envolve? Você está vendo a mãe estressada porque o filho está doente e você não se envolve?( Enf. 11)

Com a criança eu vejo um resultado a mais. Ela me acalenta mais do que o idoso, que já sofreu muita coisa na vida. Com a criança tem um time e uma garra maior para viver ainda. (Enf. 11) 
Para os enfermeiros, um dos grandes benefícios da teoria de Watson - exatamente por evidenciar sentimentos de amor, carinho e respeito, por exemplo - é a valorização do ser humano que interage no momento do cuidado, o que envolve, tanto os profissionais como o paciente.

(A teoria) valoriza as duas vertentes: tanto a equipe como o paciente. É uma valorização do ser humano como um todo. Acho que é a valorização daquilo que você faz, do que você pode fazer melhor e sabe por que está fazendo. (Enf. 3)

O próximo carative fator/ caritas process da teoria de Watson referese ao sistema de crenças e ao papel do enfermeiro em permitir que a fé e a esperança estejam presentes nos momentos de cuidado:

2. CF (1979): Promoção da fé e esperança;

CP (2008): Estar autenticamente presente; permitir/sustentar/respeitar profundamente o sistema de crenças e o mundo subjetivo do self/outro.

Promover fé e esperança são atitudes relacionadas com a presença autêntica do profissional para aceitar a subjetividade e o sistema de crenças do self e do ser cuidado. Estar autenticamente presente, segundo Watson (2008), é um convite para os enfermeiros honrarem as próprias crenças como parte da relação de cuidado, a fim de promover e aceitar o potencial que a fé e a esperança têm para transformar as experiências de vida das pessoas. Desta forma, conseguem colocar-se melhor na referência do outro para compreender os significados atribuídos às experiências de cada indivíduo.

Estar presente no sistema de crenças da família, assim como reconhecer e sustentar aquelas que fazem parte do universo subjetivo do profissional são atributos importantes, que fortalecem os enfermeiros na continuidade do cuidado, especialmente quando se depara com situações de sofrimento decorrentes da proximidade com as vivências da criança e da família. Por isso, acreditar em algo maior ajuda os enfermeiros a darem sentido às experiências que vivenciam e, assim, manejar o sofrimento para seguir adiante. Nesse sentido, os fatores intrínsecos resgatados das experiências pessoais de cada profissional, como ter sensibilidade, 
sabedoria, capacidade de manejo e maturidade, influenciam nesse processo.

Deus é muito perfeito porque ele te dá forças. Assim, no dia seguinte, a gente consegue voltar (ao trabalho). Tudo vai muito da crença da pessoa, eu acredito. (Enf. 11)

Acho que a religião ajuda também. É importante acreditar em algo maior, saber que a gente está aqui ajudando da melhor forma!

(Enf. 12)

Se a pessoa não gosta do trabalho porque é incompatível com o que ela acredita, a guerra já está perdida (...) Tem que ter um significado do que se faz: pessoal, moral e religioso. (Enf. 12)

Esse sistema de crenças permite aos enfermeiros desvelar os significados de suas experiências, principalmente, a compreensão de cuidado e da profissão. O referencial revela aos profissionais uma emoção relacionada ao resgate do significado do cuidado, o que para eles pode se perder em meio às rotinas da instituição. Discutir um referencial para 0 cuidado e adequá-lo à prática é uma forma de exaltar a importância da profissão e ajudar a desenvolver um relacionamento com as famílias.

É como recordar o porquê se está nessa profissão e o que te fez escolher! Quando eu fui à aula e vi a teoria, achei aquela conversa muito boa. Nossa! Foi ótimo! (...) É uma profissão difícil, é sofrida, mas a essência o profissional descobre! (Enf. 5)

Acho que esse referencial veio abrir os olhos para resgatar o que a gente via lá no começo da enfermagem e está começando a deixar para trás. (Enf. 7)

Buscar significado para a prática da enfermagem move o sistema de crenças dos enfermeiros dando sentido ao relacionamento com a família. Para eles, o exercício da profissão reflete, de alguma forma, uma necessidade, muitas vezes inconsciente, de envolvimento e doação maior do que exigem outras profissões. Isso pelo fato de lidar constantemente com situações de sofrimento do ser humano. Por isso, é preciso cultivar um sentimento de estima pela profissão.

Ter amor pelo seu trabalho. Porque você sabe e acredita que faz alguma diferença (...). Toda profissão tem seu lado de doação, não só a enfermagem. Talvez aquelas que lidam com o ser humano deixam mais claro para as pessoas de fora que existe uma doação. 
Mas quando a gente que está trabalhando, não percebe muito isso!

(Enf. 11)

3. CF (1979): Cultivo da sensibilidade para si mesmo e para os outros;

CP (2008): Cultivar suas próprias práticas espirituais, aprofundando a autoconsciência, para além do ego.

Esse processo da teoria de Watson (2008) retoma o envolvimento dos enfermeiros em cultivar o amor, a gentileza e o sistema de crenças, mas inclui o fato de estarmos inseridos em uma dimensão espiritual maior. É a partir dessas experiências que podemos ser sensíveis ao self e ao outro. É dessa forma que os enfermeiros têm a possibilidade de explicitar sentimentos que permitam alcançar um real compromisso com o caringhealing, com a unicidade, complexidade e totalidade do ser.

Watson (2008:68) explora a relação entre os sentimentos e a natureza do ser humano, dizendo que "frequentemente nós nos permitimos pensar nossos pensamentos, mas não sentir nossos sentimentos”, demonstrando a necessidade de práticas que favoreçam a reflexão e aceitação dos nossos sentimentos e pensamentos, tanto os prazerosos, como os desagradáveis.

Práticas para aprofundar a autoconsciência e promover maior sensibilidade para si e para o outro incluem estratégias que possibilitem aos enfermeiros refletirem sobre o cuidado oferecido à criança e à família. $O$ material oferecido para os enfermeiros na oficina, na fase de coleta de dados, permitiu-lhes reconhecer que expressões e reações podem influenciar a relação com as famílias e, por isso, as reflexões favoreceram uma postura mais ajustada e crítica para poder se perceber mais e, consequentemente, ajudar a formação dos valores e prática genuína e equânime do cuidado.

Acho que a teoria ajudou bastante! Mesmo nas relações entre a equipe, a meu ver, consegui me controlar mais: não explodir, tentar respirar e ver as coisas com mais calma; me perceber mais para poder também ajudar. Acho que, nesse sentido, a teoria me clareou algumas coisas. (Enf.11)

Às vezes a resposta que a gente dá, é porque a gente não parou para pensar! Você percebe que as relações são influenciadas 
pela sua postura e seu jeito de falar. Então para, respira um pouco e fala: 'eu ia dar essa resposta, mas o que eu quero com isso?' Acho que fui tentando me centrar mais, me perceber mais, para poder

também ajudar. (Enf. 11)

Dessa forma, os enfermeiros adquirem consciência de si e do seu papel na interação com o outro, o que lhes permite compreender melhor 0 momento que cada família vivencia e suas expectativas. Para isso, é preciso ser sensível para captar o caráter humano do cuidado e, assim, desenvolver um relacionamento de ajuda e confiança.

Com a teoria, é possível tentar ver como cada um está sentindo seu cuidado no momento e a importância para ele (o enfermeiro), para o paciente e para o familiar. (...) Acho que perdemos um pouco a percepção do outro como um todo, como um ser completo que às vezes está ali fragilizado. (...) Tentar entender como a família enxerga esse momento é bom, até para não ter um erro como consequência. É bom também para o familiar se sentir acolhido e não como mais um.

(Enf. 3)

Se a gente escolheu a enfermagem não é só para fazer a parte técnica. Tem aquele ideal do que é ser enfermeiro... cuidar. É o que nos torna diferentes do médico. A gente não está aqui só para executar procedimentos. A gente está aqui para fazer diferente, para dar um caráter humano para o cuidar. (Enf. 5)

Os fatores descritos até aqui - valorização do ser humano e dos sentimentos envolvidos na interação, as crenças, busca de significados para o cuidado e para a profissão, uso da sensibilidade - agregam os potenciais necessários reconhecidos pelos enfermeiros para que eles integrem uma consciência plena para o cuidado, de maneira que promova uma percepção de si mesmo e dos outros. Algumas ações praticadas pelos enfermeiros apontam para o fato de esses valores e capacidades já estarem incorporados intrinsecamente, de alguma forma, nos relacionamentos com a família.

Ter consciência daquilo que você está fazendo (...) Isso influencia a criança e também o seu cuidado. (Enf. 3)

( $A$ equipe) foi aprendendo a lidar com a família dentro da UTI, criando vínculos, laços, tendo muitas historias de amor; também algumas de desamor. Acho que ficou muito melhor para a criança (...) $E$ de repente, quando eu via, elas (as enfermeiras) estavam brilhando e fazendo um cuidado muito humanizado, muito feliz e leve (Enf. 4) 
Eu vejo muitos dos enfermeiros que, no começo, ficavam meio desconfiados, hoje já têm esse movimento de trazer a família mais perto e querer uma aproximação. Quando não tem ninguém, a gente até estranha: Como? Vai ficar sozinho? (Enf. 11)

Para os enfermeiros, integrar a consciência de cuidado, como forma de cultivar a sensibilidade para si mesmo e para os outros, não é apenas um movimento interno, mas algo que se constrói com a equipe e a instituição para manter o foco no relacionamento com a família. Para eles, a compreensão de que existir uma forma de cuidado mais uniforme entre o grupo é importante para manter uma cultura de cuidado, envolvendo o relacionamento de ajuda e confiança com a família. As práticas autênticas permitem a manifestação do self de forma criativa e mais incisiva para desenvolver um relacionamento com o outro, o que se expressa a partir de uma cultura do contexto de cuidar.

Acho também que (aplicar a teoria) nem é escolha de cada enfermeiro. É uma cultura, talvez (...) a gente vai se percebendo dentro da cultura, não é? (Enf. 1)

Sempre teve esse foco (na família), pela filosofia nossa, das encarregadas, que a gente desenvolveu ao longo desse tempo. Uma cultura, você vai criando e difunde, não é? E as pessoas que vão chegando ou se adaptam a essa cultura ou não tem como! (Enf. 10)

Assim, considerar a natureza dinâmica das relações e integrar a consciência no processo de cuidado é fundamental para desenvolver uma relação de ajuda e confiança.

O próximo processo caritas da teoria de Watson permite-nos desvelar a experiência dos enfermeiros especificamente nas interações com as famílias. Trata-se do:

4. CF (1979) Desenvolvimento de uma relação de ajuda - confiança;

CP (2008) Desenvolvimento e permanência de uma autêntica relação de cuidado, de ajuda e confiança.

Nesse processo da teoria, os enfermeiros revelam os fatores que estão presentes no desenvolvimento da relação de ajuda e confiança com a família. Lembramos que estão incluídos aqui os conceitos de relacionamento transpessoal, momento de cuidado, congruência, empatia e aceitação 
positiva incondicional, apresentados mais detalhadamente na introdução deste estudo (Watson 1979; 2008).

Para os profissionais, estabelecer uma relação que evidencie melhorias na qualidade do cuidado das famílias não se limita apenas àquela construída com a criança e com a família, mas também com a equipe de enfermagem e as outras equipes que integram à assistência da criança.

As relações com as famílias foram descritas, no geral, como tranquilas, o que permite criar mais facilmente uma cumplicidade entre o profissional e a família, constituindo desse modo, uma relação de confiança.

Meu contato com a família é muito tranqüilo (...) Nunca tive problema pessoal de relacionamento. (Enf. 5)

A interação entre a equipe e o familiar, acaba criando uma cumplicidade e você conta com aquele familiar, você sabe que ele está ali do lado e que ele vai também ajudar no cuidado. E uma cumplicidade que vai também deixar você mais à vontade. (Enf. 3)

Essa confiança se mostra, para os enfermeiros, quando algumas famílias procuram a enfermagem para compartilhar suas angústias, o que facilita o engajamento e ajuda o fortalecimento do vínculo do profissional com os familiares, o que não é possível conseguir realizando puramente os cuidados técnicos habituais. Assim, quando a iniciativa de iniciar uma aproximação é da família, os enfermeiros sentem-se mais tranquilos para engajar-se. Existe uma dificuldade desses profissionais em promover e reconhecer, por mecanismos próprios, os fatores que motivaram uma relação de confiança. Eles acreditam que têm boas oportunidades para desenvolver um relacionamento de ajuda e confiança com as famílias pelo fato de estarem sempre em contato com elas.

Estamos ao lado do paciente 24 horas. Tem pessoas que vêm desabafar coisas que você pensa: 'Porque será que ela ta me falando isso?' É que você demonstrou e a pessoa confiou você pra falar. Se o enfermeiro se fechar e ficar só nessa parte mecanizada de protocolo e blá, blá, blá que é importante, mas não é essencial, perde a chance de fazer a diferença. (Enf. 5)

Acho que isso é fundamental: adquirir a confiança da família para desenvolver o trabalho melhor. A gente se sente mais seguro para fazer uma medicação, um curativo, qualquer coisa. (Enf. 1) 
Pensando em desenvolver um relacionamento de ajuda e confiança, alguns elementos são fundamentais, para garantir e promover um cuidado integrado e respaldado em valores humanos. A comunicação está entre esses elementos, dentre os quais se destaca a escuta à família, para perceber e compreender melhor os comportamentos expressos e, dessa forma, direcionar práticas individualizadas para o cuidado.

Posso até muitas vezes não concordar com o que eu estou ouvindo, mas acho que é primordial ouvir o que a família tem a dizer. $E$ hoje em dia tem muitas crianças grandonas, mesmo adolescentes, que se você não parar para ouvir, seu cuidado não valeu de nada.

(Enf. 11)

Eles se sentem acolhidos a partir do momento em que são ouvidos. Eles conhecem os filhos deles e muitas vezes você vê que nem escutam o que eles têm para dizer. Cinco minutos que você fica a mais no quarto, ouvindo a avó, a mãe, faz diferença nesse momento de fragilização. (Enf. 9)

Apesar disso, os enfermeiros acreditam que esses momentos precisam ser mais explorados pelos profissionais, pois consideram que, na prática, ainda ouvem muito pouco os pacientes. Dessa forma, existe uma falta de aptidão e habilidade para promover uma escuta ativa, congruente com as necessidades terapêuticas de cada um e, embora reconheçam a importância da comunicação, veem pouco envolvimento do profissional, nesse sentido, com as famílias. Eles ainda sentem-se carentes de intencionalidade para ouvir o outro, ainda que percebam isso como parte do cuidado e de atributos do enfermeiro.

Eu acho que, como profissional, a gente conversa muito pouco com o paciente. A gente quer muito falar, mas ouve muito pouco.

Precisamos ouvir, observar e entender mais também. (Enf. 5)

Para o relacionamento autêntico de ajuda e confiança, os enfermeiros também acreditam que é necessário promover a empatia. Para isso, conhecer a criança e a família é necessário para incluir-se no sistema de referência do outro e melhorar a qualidade no processo de interação.

A gente procura entender o lado da família. Se eu me colocasse no lugar dela, talvez agisse da mesma forma ou até pior e também ficasse com medo! (...) Então eu procuro entender, para não ficar julgando tanto. (Enf. 11) 
Basicamente olhar para o outro e me colocar no lugar dele. Então, a partir disso, eu consigo negociar várias coisas (...) sempre pensando no que o outro está sentindo. (Enf. 12)

Se você consegue conquistar a família, se você tem um bom relacionamento interpessoal, se você consegue aplicar essa empatia, você conquista o cliente. Ter o cliente do seu lado, é tudo! (Enf. 9)

A interação do enfermeiro com a família pela ocasião do cuidado envolve manifestações e gestos consistentes com o respeito, gentileza e presença autêntica para formar a relação de ajuda e confiança. Esses gestos pressupõem a prática consciente e intencional do toque, do carinho, dos gestos e da comunicação não-verbal para confortar o ser humano, o que permite que o relacionamento entre enfermeiros, famílias e crianças possa se constituir, tal como propõe a Teoria do Cuidado Humano.

Ter um cuidado na hora de tocar, na hora de falar (...) profissionalmente vai ter um fruto de um cuidado melhor para 0 paciente. (Enf. 4)

Para a família que me viu chegar e colocar um travesseirinho assim... debaixo da mão da criança, com carinho... Aquilo para a família é tudo! (Enf. 8)

Para os enfermeiros, as relações com a equipe ajudam a manter condições favoráveis para o engajamento das relações interpessoais. É fundamental o apoio, a compreensão e a troca de experiências entre os profissionais, objetivando qualidade no cuidado ou, mais especificamente, no relacionamento com a família. Os enfermeiros que possuem um cargo gerencial consideram-se responsáveis por ajudar os profissionais da equipe a enfrentarem os momentos de vulnerabilidade, quando se deparam com situações de morte ou de dificuldade no contato com a família. Assim, tornam-se cuidadores dos enfermeiros, sendo necessário incluir os valores humanos também nessas relações entre os membros da equipe, para fortalecer e preparar o profissional que precisa cuidar das crianças e das famílias.

Desta maneira, zelar pelo contexto onde ocorrem essas interações é muito importante. Isto é feito objetivando construir parcerias. Por isso, é necessário tratar os colegas com cumplicidade, apoiá-los, evitar fazer 
críticas que não sejam construtivas e oferecer ajuda. Todas essas são estratégias destinadas à construção de um ambiente de confiança e reciprocidade. Ser prestativo, altruísta, é fundamental em todos os sentidos nas relações de trabalho em equipe.

O cuidado tem que ter o mínimo de estrutura tanto de conhecimento, quanto de recursos para que você possa pensar de modo humano. Se você está humanizada, você dá um cuidado humanizado. (Enf. 4)

Ela (uma enfermeira) chorou muito, muito, muito, não teve condições de dar plantão. Aí eu falei: 'Vai embora pra casa e metaboliza!' Muitas vezes tem de se preparar para isso e não adianta querer de modo endurecido, pensando: 'eu não vou chorar, sou a chefe e não vou deixar ninguém chorar. Levanta daí! Ele morreu, morreu mesmo. E vai trabalha! (Enf. 12)

Uma vez que os enfermeiros têm consciência e seguem um ideal de cuidado, pautado em valores humanos, têm também sensibilidade com o self para reconhecer situações em que não estão em condições de cuidar da criança ou da família. Assim, quando se sentem incapazes de cuidar ou promover o engajamento com as famílias, buscam apoio nas trocas de experiências com a equipe para discutir questões relacionadas ao cuidado. Consideram essa uma estratégia essencial, que beneficia a família e a si mesmo.

Se a colega puder cuidar daquele com que eu não me simpatizo e com que ela se relaciona bem, melhor! Por isso existe a equipe! (...) (É preciso) saber que tem dias em que não estou bem e que posso passar (a tarefa) para alguém que está melhor do que eu e que pode prestar um cuidado melhor. (Enf. 11)

No entanto, apesar da crença dos gerentes sobre a necessidade de estar ao lado dos profissionais, apoiando-os em suas necessidades e constituindo parcerias para cuidar da família, os enfermeiros sentem falta de uma relação mais sólida com a equipe, que permita a troca de experiências para agregar melhorias à qualidade da assistência oferecida às famílias. Para eles, na enfermagem, essas dificuldades são mais visíveis do que entre outros profissionais, como os médicos. Os mecanismos internos que revelam as dificuldades enfrentadas por cada profissional são pouco explorados na relação com a equipe, não permitindo compartilhá-las com os 
colegas para tentarem juntos uma alternativa para promover o engajamento e as manifestações de ajuda e confiança com a família.

A gente é pouco unida na assistência. Dificilmente você aproxima de uma colega e diz: 'Olha, estou com dificuldade com essa família. O que você me sugere?' Você não vê isso! Com médico você vê, com o enfermeiro, não! Parece que você é isolado e tem que resolver aquilo. Às vezes tem pessoas com mais facilidade, que vão te dar 'toques' (...) A gente não é uma categoria muito unida! (Enf. 5)

Adicionalmente, pelo constante contato com a família, os enfermeiros podem ajudar a identificar momentos em que se percebem incapazes de ajudar os familiares e entendem que, nessas situações, é necessário integrar outros profissionais da equipe multidisciplinar para também ajudar a resolver o problema.

"Quando a gente vê que precisa, vê se há possibilidade de falar com psicólogo; quando tem problema com nutrição, a gente chama a nutrição. Tenta resolver! Tem a equipe dos cuidados paliativos, a assistente social para conversar! (Enf. 6)

A gente identifica que tem uma situação difícil, lançamos mão dos recursos: psicólogo, cuidado paliativo, o próprio médico! (Enf. 12)

O relacionamento de ajuda e confiança também inclui a promoção e aceitação dos próprios sentimentos positivos e negativos, assim como os da família e da criança. Esta é igualmente uma base para a interação e está mais bem explicitada no quinto carative factor/ caritas processes.

5. CF (1979) Promoção e aceitação da atitude de expressar sentimentos positivos e negativos;

CP (2008) Estar presente e apoiar a expressão de sentimentos positivos e negativos, como uma conexão profunda com o espírito do ser e do ser que cuida do outro.

Estar presente e apoiar a expressão de sentimentos positivos e negativos permite que a interação ocorra de maneira transpessoal, tal como propõe Watson (2008). A presença consciente do profissional nos momentos de cuidado é fundamental para que se desenvolva o relacionamento de ajuda e confiança do enfermeiro com a família. Para Watson (2008), esse quinto processo da teoria reforça elementos para compor o relacionamento, 
pois, devido a sua natureza dinâmica, podem ser facilmente desvalorizados e não reconhecidos na prática do profissional de enfermagem.

Para os enfermeiros, um dos sentimentos positivos que envolvem 0 próprio self é o reconhecimento de suas ações enquanto profissional. Não apenas quando a instituição valoriza e reconhece o seu trabalho, mas também quando eles percebem as repercussões das suas ações de cuidado nas expressões de gratificação da família, emergindo sentimentos como a satisfação, bondade, generosidade e altruísmo. Esses sentimentos positivos são formas plenas de valorizar o trabalho e o amor pela profissão. As expressões demonstradas pelas famílias são as mais diversas: sorrisos, agradecimentos, cartas e convites para festas de aniversário. São atitudes que têm o significado de laços de afeto, e representam uma conexão que ultrapassa os limites do contato puramente físico e técnico.

Reconhecimento vem do vínculo que a gente cria. Tanto que tem crianças que saem daqui e a gente é convidada até pra ir à festa de aniversário! Quer dizer: não foi só a coisa triste da internação. Ficou algo positivo do nosso trabalho bem feito. (Enf. 7)

(É importante) saber que o meu serviço ajudou um pouquinho que seja alguém. Quando a gente recebe uma carta... recebe um sorriso da família, um obrigado, a gente sente que fez alguma coisa, que não foi em vão. (Enf. 11)

Os enfermeiros percebem o reconhecimento de outra pessoa quando conseguem mostrar seu trabalho com propriedade e competência, a partir do momento em que se sentem seguros e externalizam seus pensamentos e raciocínios, de forma concisa e clara. Eles demonstram estarem sempre preparados e, dessa forma, tornam-se referência no meio profissional, declarando um status de poder ainda mais evidente em um ambiente com elevada tecnologia, como uma UTI, por exemplo, que exige conhecimentos técnicos específicos.

Os enfermeiros ainda identificaram desafios para atribuir um significado à presença da família no contexto de cuidado da criança, mostrando que, embora reconheçam progressos nessas interações ao longo de suas experiências, muitas dificuldades se fazem presentes nesse engajamento para desenvolverem um relacionamento de ajuda e confiança. 
Isso ocorre especialmente com os enfermeiros que vivenciaram épocas em que a presença de familiares junto à criança não era permitida e os encontros aconteciam apenas nos momentos de visita. A aprovação do Estatuto da Criança e do Adolescente garantiu a presença do acompanhante e trouxe um novo contexto para esses profissionais que involuntariamente se viram tendo que dividir "seu" espaço de trabalho. Dificuldades surgiram nessa nova relação, principalmente pelo fato de os enfermeiros pouco conhecerem seus papéis no relacionamento com a família.

A UTI era um ambiente onde quem dominava era a equipe. $A$ equipe era técnica, dona do seu conhecimento. Ela que ORIENTAVA a mãe, PERMITIA, LIBERAVA! Então às vezes quando a mãe se apoderava de alguma coisa que era do espaço da equipe, aquilo criava um conflito. (Enf. 4)

Ainda tem aquele conceito de que pai e mãe vão vigiar o seu serviço. A gente já passou por isso, mas depois vimos o quanto isso deve ser desmistificado e o quanto eles nos auxiliam. (Enf. 3)

No começo eu tinha muito medo de ter o familiar junto. Não entendia qual era sua função. (Enf. 11)

A dificuldade dos enfermeiros em aceitar e entender os sentimentos da família se faz presente quando esta expressa suas emoções. Diante Nessas circunstâncias, os profissionais se sentem receosos, inseguros e despreparados para lidar com os comportamentos da família, valorizando a forma como as atitudes dos familiares repercutem neles e não se movimentando para compreender essas expressões como reflexo dos sentimentos envolvidos em cada experiência.

Os mecanismos que permitem ao enfermeiro manejar essas situações são frágeis e, por vezes, ele se percebe distanciando do contato com a família, mesmo sabendo que dessa forma não corresponderá às expectativas deles. O receio de envolver-se com as experiências de sofrimento do outro e as dificuldades em atender as necessidades das famílias que fogem do seu controle são as principais causas que promovem esse afastamento, segundo os enfermeiros.

Quando não tem essa coisa de família, você vai, faz o cuidado, vira as costas e vai embora! Agora com a mãe, não! Ela questiona tudo o que você vai fazer. Então você tem que ter muita certeza, tem 
que estudar muito. E assim, é o perfil de cada um, mas eu sou insegura. Precisei estudar muito no começo para me sentir segura, e conversar com a família, para justificar tudo o que eu faço! (Enf. 9)

Muitas vezes se a família está muito arisca, o profissional tem um certo medo, um receio de se aproximar. Tudo eles questionam.

Desconfiam se você está fazendo certo ou não! (Enf. 6)

"Eu acho que a enfermagem tem que se manter presente. Às vezes a gente se distancia, não só porque a família é difícil. A gente acaba se distanciando pelo sofrimento mesmo. Às vezes a gente não quer se envolver mesmo, mas não é isso que as pessoas esperam da gente, não é! (Enf. 7)

O cuidado como forma de contato, conexão entre duas ou mais pessoas, acaba interrompido quando as necessidades de uma das partes não são percebidas. Se as expectativas dos profissionais ou da família não são satisfeitas, as relações se deterioram. É assim que os enfermeiros explicam os mecanismos que os fazem afastar-se da família e a serem mal avaliados por suas atitudes. Criam-se ações, reações emocionais e estratégias que podem se tornar cristalizadas e limitam a espontaneidade, flexibilidade e a capacidade para compreender os sentimentos negativos que repercutem nos comportamentos, prejudicando 0 engajamento e 0 desenvolvimento do relacionamento com os familiares.

A falta de consciência para entender esses sentimentos negativos e desenvolver a relação com a família dificulta a promoção da empatia que, para os enfermeiros, é fundamental para humanizar as relações. Desta forma, tornam-se frágeis as interações e dão abertura ao julgamento do outro, o que aparece como uma contradição nos discursos, já que os enfermeiros reconhecem a inadequação de qualquer julgamento, diante do fato de a família se encontrar em situação de sofrimento e fragilidade.

Eu cheguei um dia para trabalhar e as técnicas falaram: 'Ah! vai lá porque tem uma mãe que é folgada, nem troca a fralda, só fica lá olhando pra cara dele!'Aí vou eu lá falar com a "folgada". (...) Depois

que eu consegui conversar, levei para a equipe o que tinha acontecido, e fui percebendo que antes de julgarem alguma mãe, tentavam se aproximar e ouvir (o que ela tinha para dizer). Então acho que se você não conhece o problema, você acaba julgando. (Enf. 11) 
Para as gerentes de enfermagem, as interações com a família ainda carregam inúmeros desafios quanto à carência de competências e habilidades dos profissionais para assistirem também a família, principalmente em unidades que atendem adultos e idosos. Os profissionais que cuidam de crianças, uma vez que se deparam constantemente com a família, adquirem hábitos mais próximos do cuidado da família, aceitando melhor a presença do outro e desenvolvendo habilidades para 0 engajamento. No entanto, apesar de existir esse contato, o foco das ações de cuidado ainda não é centrado na família, embora acreditem nisso. Isto fica mais evidente durante os procedimentos realizados com a criança, pois vemos que as estratégias para aliviar o sofrimento, estresse e ansiedade da mãe não acontecem. As expressões negativas dos familiares afetam 0 enfermeiro emocionalmente e a falta de consciência das habilidades e estratégias para lidar com os sentimentos negativos dos familiares os faz sentir mais vulneráveis.

É claro que, para tudo tem exceção. Tem aqueles casos em que, na presença da mãe, fica mais difícil. Uma punção venosa, por exemplo, em que a mãe fica ansiosa. Aquela ansiedade passa para a criança! Então há casos em que até a gente, pede para mãe dar uma licencinha se ela quiser. Daí, se ela, aceita, ela sai. Se não aceita, ela continua lá e a gente tem que lidar com a ansiedade da mãe também.

(Enf. 9)

Acho que ele (cuidado com a família) está mais desenvolvido nas unidades infantis. Falar de família na UTI adulto ainda é muito complicado. (Enf. 4)

6. CF (1979) Uso sistemático do método de resolução de problemas para tomada de decisão (redefinido em 1985: uso do processo de cuidado criativo na resolução de problemas);

CP (2008) Uso criativo do ser, de todas as formas de conhecer/ser/fazer, como parte do processo de cuidado (engajando artisticamente a prática do cuidado).

O uso criativo do ser e todas as formas do saber são a união dos conhecimentos sistemáticos, adquiridos das experiências acadêmicas e científicas com as práticas artísticas que necessitam de criatividade, intuição, ética e estética, além das experiências pessoais de vida. 
A rigidez das formalidades na função dos enfermeiros, associada ao ritmo acelerado de conhecimento tecnológico trouxe à enfermagem uma mentalidade pobre em consciência, pouco crítica e intencional (Watson, 2008). Perceber a união científica e criativa, proposta por Watson (2008), atribuindo a essas duas vertentes a mesma importância no processo do cuidado, dá sentido à aparente contradição do exercício da autenticidade do profissional, com as evidências formais e sistemáticas das técnicas e procedimentos executados.

As expressões criativas e artísticas específicas no processo de cuidado com as famílias aparecem nesse ambiente, mas não propriamente como ações dos enfermeiros. A promoção de experiências saudáveis nas interações de saúde são realizadas por grupos externos è equipe de saúde e agem, cantando para os pacientes ou promovendo experiências de alegria, por meio da arte do palhaço, junto às crianças hospitalizadas.

Embora esses encontros contribuam para melhorar a qualidade das relações de saúde dentro do hospital, entre famílias, crianças e profissionais de saúde, os enfermeiros acreditam que, para estabelecer um relacionamento de ajuda e confiança, precisam focalizar em ações criativas que atendam às diversas necessidades das famílias no cotidiano, tornando a experiência mais agradável aos envolvidos no momento de cuidado.

Não me interessava muito ter o programa doutores da alegria ou contadores de historia, como a gente já teve e, tem ainda, se eu chego, por minha necessidade, em pleno inverno, acordo um bebê para tomar banho no leito. (...) Tem que pensar nessa alegria no dia a dia com a família. (Enf. 4)

A gente vai cantar no quarto do paciente (...) É uma forma de tentar um cuidado mais próximo e mais acolhedor. (Enf. 4)

7. CF (1979) Promover ensino-aprendizagem interpessoal;

CP (2008) Engajamento em uma experiência genuína de ensinoaprendizagem que atenda a pessoa como um todo, tentando permanecer na estrutura referencial do outro.

O envolvimento dos enfermeiros no processo de ensinoaprendizagem de forma transpessoal requer habilidades que lhe permitam se conectar aos sentimentos, preocupações, conhecimentos e compreensão 
do outro. Essa conexão favorece para o paciente se torne sujeito do seu próprio cuidado, que possa gerir suas necessidades e ter o conhecimento de suas capacidades. Esse processo deve envolver tanto os familiares quanto a equipe de enfermagem. Para promover essa experiência com a família, os enfermeiros sentem que devem zelar e esclarecer os direitos dos responsáveis pela criança, da mesma forma que precisam compartilhar informações com os pais sobre procedimentos realizados com a criança e seu estado de saúde.

Tanto que na UTI, quando chega o pai, a gente fala: 'Olha, você tem o direito de permanecer. Isso não quer dizer que você tem obrigação de ficar!'. Tem que deixar bem claro que para ele, é direito!

(Enf. 11)

Então muitas vezes, dependendo do que está acontecendo com a criança, eu trago a família na porta e falo: 'Olha, os médicos estão lá e está tudo bem. Só está demorando porque é um procedimento longo. Fica em paz, fica calma e tal'. Então isso traz tranquilidade para eles. Você consegue trazer um bem estar para família e para o paciente. (Enf. 8)

Os enfermeiros relatam experiências significativas do próprio processo ensino-aprendizagem que poderiam ajudar no desenvolvimento de competências e na conscientização para promover o relacionamento de ajuda e confiança entre a equipe e a família. Dessa forma, acreditam que precisam investir em experiências que favoreçam discussões com a equipe para prover um contato mais intencional com a família e com a criança, viabilizando contínuas estratégias de ensino-aprendizagem.

Eu acho que ter reuniões, trazendo alguns casos, analisando pela visão da teoria, seria bom. Você poder falar: 'Olha, eu percebi isso, aconteceu isso'. Vai clareando a cabeça da gente. É um exercício e, quanto mais você vai fazendo esse exercício, mais prática vai pegando e entendendo tudo mais rápido. (Enf. 11)

Vemos que o blá, blá, blá, a aula formal, o treinamento formal, não tem demonstrado tanto resultado (para promover mudanças). (...) Talvez partindo de "cases", por exemplo, como posso me fundamentar para poder, em outra situação, agir de outra forma - e não desta - Ir exercitando. Fazer um estudo de caso, ser lançado em um problema

e...se vire! Como é que a gente faria? Qual seria a melhor abordagem? A partir daí, olha você fez isso. Isso é a comunicação! 
A oportunidade de compartilhar com os colegas estratégias de cuidado e de como se engajar e desenvolver um relacionamento de ajuda e confiança confortam os enfermeiros, pois eles sentem que é uma maneira de aprimorar o cuidado. O momento da passagem de plantão pode ser considerado um espaço rico para trocar experiências, levantar reflexões e discutir aspectos do cuidado da família. Para os gerentes, os enfermeiros devem se fazer presentes para a equipe, constituírem uma referência para promover mudanças de atitudes nos outros profissionais de enfermagem.

Eu falava muito com as enfermeiras, porque ela é quem ia dominar o perfil do plantão. (...) como um exemplo para a equipe ir aos poucos resignificando aquilo (as atitudes). (Enf. 4)

Eu acho que a passagem de plantão é um momento muito rico, porque às vezes a gente gasta lenha, gasta tempo, gasta voz, saliva em informações que não são necessárias. Então o momento da passagem de plantão ajuda a refletir! Às vezes eu fazia uma pergunta para a equipe sair pensando assim... (Enf. 4)

8. CF (1979) Provisão de um ambiente de apoio, proteção e/ou correção mental, física, sóciocultural e espiritual;

CP (2008) Criar um ambiente protetor em todos os níveis, onde se está consciente do todo, da beleza, do conforto, da dignidade e da paz.

As medidas para prover conforto, segurança, privacidade e dignidade humana, além das outras formas genuínas e criativas, que cuidem também do ambiente para favorecer a recuperação do individuo, são descritas por Watson (2008, 1979), congruentes com a visão de Nightingale para o cuidado. Toda e qualquer forma para diminuir o sofrimento do outro e o impacto da rigidez de um ambiente hospitalar são tentativas que um enfermeiro caritas pode utilizar para potencializar a dignidade, conforto, beleza, totalidade e paz.

Dessa forma, preocupações com o espaço físico são reveladas pelos enfermeiros, que pensam em formas de favorecer o relacionamento com a família, tentando tornar o ambiente menos agressivo possível, mais gentil, confortável e tranquilo durante uma internação. A disposição física dos espaços nas UTIs é preocupante, para os enfermeiros, que consideram o local impróprio para acomodar os pais, o que para eles também é um fator 
restritivo ao relacionamento dos familiares com a equipe. Os profissionais sentem-se desconfortáveis em não poder acolher os pais da maneira como consideram ideal.

Tem problemas físicos da UTI mesmo que a gente não tem uma disponibilidade do espaço físico. É complicado você falar com uma mãe para ficar sentada numa poltrona dura, que não tem nem conforto para tirar um cochilo. (...) Banheiros para eles também não tem aqui, tem que ir pra outro andar! Então estes certos tipos de conforto para eles também seria uma coisa assim bem mais humanizada aqui dentro, não só o tratamento! (Enf. 6)

Os enfermeiros acreditam ser importante informar aos pais que 0 hospital proporciona boas e atualizadas tecnologias. Isso favorece sentimentos de segurança e conforto aos familiares por saberem que o filho está recebendo as melhores formas de tratamento. Dentro desse contexto, os enfermeiros retratam uma preocupação em prover um ambiente protetor em todos os níveis, como prevê este sétimo processo da teoria. Ao mesmo tempo, os profissionais reforçam que o ambiente, como de uma UTI, pode assustar pela quantidade de aparelhos e também por uma visão estigmatizada do local. Por isso, muitas vezes é necessário desmistificar a associação da UTI com a gravidade do quadro de uma criança, para tentar tranquilizar a família.

Os profissionais temem as reações dos familiares frente ao quadro da criança associado ao ambiente tenso da UTI. Assim, sentem-se também vulneráveis nesse ambiente, pois, caso os pais expressem seus sentimentos de ansiedade e preocupação, o ambiente do profissional também estará ameaçado, gerando mais insegurança para estabelecer um relacionamento de ajuda e confiança com a família.

Precisa de uma condição, uma estrutura, com recurso físico, de equipamento e de recursos humanos minimamente seguros para que você possa inclusive humanizar. (Enf. 4)

A gente vai procurando deixar a internação uma coisa não muito pesada pra eles, porque falou em UTI! Eles pensam: Está grave! Então a gente tenta deixar o ambiente um pouco mais ameno e, muitas vezes, até mais familiar. (Enf. 6) 
(...) Porque você está numa UTI, às vezes a criança não tem nada! Está lá porque não tem uma vaga na pediatria. Mas o fato de internar na UTI deixa os pais estressadíssimos. (Enf. 9)

O momento do banho da criança foi abordado pelos enfermeiros, pelo fato de ajudá-los a promover com relativa facilidade conforto, proteção e dignidade para a criança e para a família no ambiente onde se encontram. Esse momento, segundo os profissionais, é muito importante para a mãe e para a criança, pois representa uma das atividades comuns que é dificultada nas ocasiões em que a saúde estiver instável. Para os enfermeiros, é uma oportunidade de firmar vínculos com a família, de estabelecer um relacionamento de ajuda e confiança, de uma forma relativamente simples, pois pode demonstrar flexibilidade para a família com relação aos horários. É uma ação que pode ser realizada da maneira como os pais estão acostumados a fazer em casa.

A gente começou a mudar inclusive horário de banho. Acabou rotina de banho! Vamos nos dividir! A criança está podendo, está querendo, já acordou e tal... Vamos nos dividir e organizar! Eu sempre falei: 'como que a mãe faz?' A criança já vem com uma história: Como que ela dá o banho?' A gente pode muito aproximar o que é da vida dela, não é? (Enf. 4)

Então mesmo com as crianças em estado gravíssimo, a família sempre participou no cuidado, ajudando. A gente vai dar banho? A gente pede para a mãe passar creme, que é um momento de carinho, de acariciar a criança e ajudar no banho. (Enf. 10)

Outra estratégia utilizada pelos enfermeiros para prover um ambiente protetor e conforto no espaço de cuidado da criança é estimular a família a trazer para o hospital objetos e brinquedos de casa ou mesmo trabalhar com os brinquedos terapêuticos que a própria unidade oferece. Alguns outros exemplos são mencionados pelas enfermeiras para retratar ações diferentes realizadas para aproximar a criança de sua realidade, considerando as necessidades de cada uma. Dessa forma, os enfermeiros reconhecem com mais facilidade o potencial que o contato, consciente e individualizado entre profissional e a família, tem para iniciar e desenvolver um relacionamento de ajuda e confiança. 
A gente tenta tornar o ambiente menos hostil possível. Então já

trouxemos cachorro, ídolos, várias... (experiências) para tentar amenizar o sofrimento da criança. Trouxemos uma menina de $6-7$ anos que não conhecia o irmão. (...) até animal de um Sr. que morria

de saudade do papagaio. E veio o papagaio. A gente vai cantar no quarto do paciente. (...) tentando fazer um cuidado mais próximo, mais acolhedor. (Enf. 4)

Ah! brinquedos a gente tenta pedir para ver se os pais têm alguma coisa para trazer da criança. Tem o brinquedo terapêutico aí, à disposição. Então são coisas que vão ajudando a criança também a se ambientar. Tem aquela dificuldade de se ambientar com a pessoa que não conhece. Então a gente tenta cativar a criança. (Enf. 6)

9. CF (1979) Assistir as necessidades humanas com satisfação/ gratificação;

CP (2008) Assistir com respeito as necessidades básicas, mantendo um cuidado intencional e consciente do espírito, enquanto unidade do ser.

Nesse processo da Teoria do Cuidado Humano, Watson (2008) argumenta que o enfermeiro tem a oportunidade de se fazer presente no momento de ajudar o outro em suas necessidades fundamentais, em especial quando ele está vulnerável. Assim, entrar no universo privativo de alguém pelo contato com o corpo físico fragilizado, tendo como respaldo a consciência caritas é uma oportunidade única de cultivar a "morada" do ser espiritual.

\footnotetext{
“... parece que em algum lugar, ao longo do caminho, a enfermagem retrocedeu desta conexão e esqueceu que uma das maiores honras que alguém pode ter é cuidar de outra pessoa que necessita. É a maior contribuição para a sociedade e para as necessidades humanas - um presente para a civilização". (Watson, 2008:144).
}

As exigências humanas básicas são convergentes com as necessidades espirituais e, portanto, temos que ter consciência de que cada ação física no corpo de outra pessoa é uma forma de tocar um ser em evolução espiritual e fazer diferença na vida do outro naquele momento.

Entre as várias necessidades básicas que o enfermeiro tem a oportunidade de administrar, Watson $(2008,1979)$ cita a presença dos laços fraternos. Por isso, integrar a família no cuidado é essencial. Buscar pessoas significativas para o momento de cuidado é uma forma de aproximar 
pessoas importantes para a criança, segundo os enfermeiros, ajudando-os no desenvolvimento da relação de ajuda e confiança com a família. Para isso, os profissionais da enfermagem exercem sua autonomia e criatividade a fim de transpor a rigidez das normas da instituição, que acreditam prejudicar o relacionamento deles com as famílias. Além de favorecer a criança, fortalece 0 vinculo entre os familiares e 0 profissional de enfermagem.

Então eu falava (para família): 'Vem um pouquinho'. Tipo o médico saiu, tá tranquilo, então começávamos a burlar e a tarde eles entravam. A gente ia deixando (...). Eu ficava às vezes uma tarde com criança no colo. Porque você tinha que substituir o lugar da mãe, de acolhimento, de aconchego daquela criança. Eu, pelo menos, não conseguia ver aquela situação. (Enf. 4)

10. CF (1979) A permissão de forças fenomenológicas - existenciais (redefinida em 85: dimensão existencial - fenomenológico - espiritual);

CP (2008) Estar presente e aberto para as dimensões existenciais desconhecidas do sofrimento entre vida-morte; "permitindo um milagre".

Esse é o processo da teoria que Watson considera o mais difícil de compreender, em parte pela natureza abstrata da linguagem e dos termos. O que a autora pretende é mostrar que, de forma consciente, nós não temos, pela natureza humana à qual pertencemos, todas as respostas para a vida e morte, assim como para as condições que enfrentamos. Por isso, podemos considerar uma força maior, que permita até mesmo a existência de um "milagre" na vida do outro. Quando uma pessoa passa por uma experiência de sofrimento que traz mudanças em sua vida, enfrenta uma crise existencial e espiritual, em que procura significados para aquela condição.

Os enfermeiros reconhecem que existe na sua relação com o outro, bem como na relação com a profissão, questões que vão além das habilidades pessoais e acabam limitando-os em sua ação. Em algumas esferas, ele não pode se frustrar ou considerar-se insuficiente em seus objetivos, e sim, estar aberto e permitir que certas coisas não são esclarecidas plenamente no relacionamento com a família, principalmente quando envolve situações de sofrimento, no processo de doença da criança. 
Não sou detentora do poder, eu não sei tudo o que acontece. E saber partilhar com aquele que é mais próximo do meu paciente e compreender que ele está num processo de doença, e a gente sabe que esse processo tem algumas quebras. Que você está ali, você se

envolve, se machuca. Algumas questões ficam além do que você pode resolver! (Enf. 11)

11. Avaliando a experiência

Esse tema emergiu, considerando os reflexos do relacionamento de ajuda e confiança com famílias para a experiência dos enfermeiros que trabalham com crianças. Nesse tema pudemos formar três subcategorias de análise: Reconhecendo um referencial para o cuidado; considerando o contexto das instituições e superando os desafios do relacionamento com a família. A primeira representa a importância atribuída pelos enfermeiros para terem um respaldo em suas ações. A segunda, aborda a influência das instituições no desenvolvimento da relação de ajuda e confiança, segundo a experiência dos enfermeiros; e a última refere-se aos fatores que podem influenciar o desenvolvimento da relação entre enfermeiros e famílias, compreendendo que as interações de cuidado, tal como argumentadas no referencial, são formas de superar dificuldades nesse relacionamento.

Em reconhecendo um referencial para o cuidado, os enfermeiros atribuem à prática que, realizam no cuidado com as famílias, um caráter, na maioria das vezes, intuitivo. Sendo assim, não reconhecem formas de expressar o cuidado humano pautado em conhecimentos teóricos, apesar de a instituição ter um referencial de cuidado para a enfermagem. Os profissionais que mencionam esses referenciais, representados por dois gerentes e um enfermeiro voltado à assistência, questionam a articulação dos princípios teóricos na prática. Porém, nem todos os enfermeiros identificam a orientação teórica que deve nortear sua prática.

Dizem que tem a Orem e a Wanda Horta. Todo enfermeiro que chega aqui é treinado para dizer isso. Se ele vê isso na prática, é outra questão. (Enf. 4)

A gente sempre escuta falar de cuidado com a familia, trabalho humanizado, (...) mas dizer para você que já ouvi outro referencial, nunca ouvi! (Enf. 6) 
Que eu lembre agora, não! Eu já li, mas não lembro agora de autor para falar. As pessoas falam muito do cuidado, mas de referencial assim, não. (Enf. 7)

Os enfermeiros demonstram uma preocupação em procurar uma evidência científica como modelo de cuidado de enfermagem, da mesma forma que investem em conhecimentos teóricos para as práticas clínicas e para o processo de enfermagem, por exemplo. Percebe-se que há uma facilidade em aproximar os elementos teóricos à prática do enfermeiro, reconhecendo a ausência de uma evidência científica para tal.

O mais engraçado foi perceber que você faz, mas não sabe que isso é uma teoria, que isso está embasado, que tem uma teoria científica por traz disso. A gente faz instintivamente e eu não sabia que isso já era uma teoria, já existia. (Enf. 5)

As pessoas estudaram muito para dizer as maiores evidências. Então por que não trazer a maior evidência de cuidado? (Enf. 4)

A gente está fazendo a humanização, mas não tem um embasamento: 'Ah eu estou utilizando essa teoria tal, estou fazendo assim!' A gente faz pela prática mesmo. Então acho que ficou bem esclarecido: para o que a gente faz, a gente tem um embasamento!

(Enf. 1)

No entanto, reconhecer as consequências que o sensível encontro do enfermeiro com a família é mais complexo que somente compatibilizar os valores pessoais com os conceitos do referencial, ou ter um conhecimento teórico sobre o tema. Embora alguns enfermeiros digam praticar 0 relacionamento de ajuda e confiança com a família, existe uma falta de habilidade para reconhecer momentos do cuidado em que praticam essas interações como pressupõe no modelo teórico utilizado.

A gente consegue identificar os aspectos do relacionamento sim. Eu não me recordo exatamente, mas lembro que, na hora (da oficina), tinha muitas coisas que eu consegui identificar. (Enf. 9)

As práticas sistemáticas e científicas do cuidado, independentemente dos processos autênticos, criativos e artísticos que os enfermeiros utilizem, são importantes para proporcionar segurança e tranqüilidade para a prática profissional, bem como para a família que recebe os cuidados, segundo os enfermeiros. Isso pelo potencial que uma fundamentação teórica tem para 
nortear as práticas e orientar as ações, por meio do respaldo de um conhecimento científico. Dessa forma, o profissional sente-se mais apto para compreender a família e cuidar melhor do outro.

Ser um diferencial, você ter um conhecimento, ter um embasamento científico e falar com respaldo. Você ter argumento e não ser uma coisa perdida. (Enf. 9)

Se você tem uma teoria, se você tem esse material, se você tem esse conhecimento e sabe aonde buscar essa informação, isso da uma segurança e direciona melhor as ações. (Enf. 5)

Eu acho que passa mais segurança para o familiar. Ele se sente mais seguro e mais tranquilo (...)Também para o profissional (é melhor) porque muitas vezes a família fica insegura com o que a gente está fazendo. (Com um referencial), fica mais tranquilo de trabalhar, não fica tão estressante. (Enf. 6)

A categoria seguinte: considerando o contexto das instituições, refere-se ao papel das instituições no sentido de ajudar os enfermeiros no desenvolvimento da relação de ajuda e confiança no cuidado, como forma de inserir um referencial na prática do cuidado da família. Para isso ocorrer, na percepção dos enfermeiros, é fundamental que a instituição tenha uma filosofia compatível com a teoria, e a chefia apoie e se envolva junto com os enfermeiros, principalmente para pensar nas estratégias que mais se ajustem para treinar cada equipe. Nos discursos, a instituição do estudo aparece como viavel para aplicar uma teoria como essa, visto que enfatiza o desenvolvimento de ações de cuidado humano nas interações com os pacientes e suas famílias.

Eu penso que (a teoria) aqui vai bem, porque conversa com a instituição. A gente sempre batalhou para isso! (Enf. 4)

Desde que eu cheguei, existe um movimento em torno da questão da família. É obvio que, de um tempo para cá,tudo se torno mais efetivo do que no início. (...). Acho que a instituição comprando essa bandeira, ajudou bastante. (Enf. 11)

Eu acho que a instituição tem a cabeça muito aberta. (...) Acho que só de a instituição abrir a cabeça para isso (referencial), já é um grande passo. Agora, até chegar ao ideal... vamos caminhando. Mas, assim, o hospital busca o cuidado humanizado.(Enf. 7) 
Porém o apoio da instituição não acontece sozinho e deve haver uma compatibilização da filosofia com o profissional que é contratado. Cabe tanto ao profissional quanto às chefias perceberem se esses valores são de fato consistentes para trabalharem em concordância e desenvolverem as estratégias em equipe para estabelecer um relacionamento de ajuda e confiança com as famílias.

Você tem que gostar da filosofia do lugar onde você está. Acho que tudo isso influencia. Se a instituição acredita, se é uma filosofia, acho que ajuda bastante. Você consegue recursos mais rápidos, consegue apoio! (Enf. 11)

Apesar de a gente já ter passado por várias situações difíceis (...) até hoje eu não cheguei à conclusão de que o hospital perdeu sua alma. Eu acho que vale a pena. A instituição sempre valorizou isso e continuará valorizando! Isso é difícil de perder, porque esta na raiz, esta na história da instituição. (Enf. 12)

Essa aproximação dos valores dos profissionais com a política da instituição, representada pela chefia de enfermagem, é importante para dar segurança aos enfermeiros para exercerem práticas mais autênticas e criativas no cuidado. Uniformizar os conceitos centrais que envolvem as interações com a família, nos diversos níveis de hierarquia da instituição, permite ao enfermeiro ter liberdade para agir, pois cuidar do outro exige algumas vezes criatividade para promover bem estar, o que nem sempre pode estar atrelado à rigidez da instituição. Os enfermeiros relatam que podem, algumas vezes, sentirem medo de tomar decisões e fazerem algo diferente do que estão habituados por não saberem se terão respaldo da instituição.

Dessa forma, os enfermeiros se referem à necessidade de autonomia e apoio para trabalhar em favor e defesa da família. Os elementos que permitem ao enfermeiro agir nas diversas circunstâncias dependem de fatores como os conhecimentos que respaldam sua prática profissional, experiências anteriores, maturidade, capacidade de tomar decisões. Esses fatores, se consistentes com os saberes que fundamentam a visão, missão e valores da instituição, tornam os receios infundados pela certeza de que as ações zelam por um cuidado pautado em atitudes simples de carinho, 
bondade e gentileza, permeados pela honestidade e transparência, conseguidos pela comunicação eficaz na interação com o outro.

A instituição tem que dar autonomia para o enfermeiro. Às vezes você tem medo de tomar uma decisão que vai contra o que tem que fazer, mas você está vendo que naquele momento,poderiam ser aberto uma exceção! Eu acho que você tem que sentir essa flexibilidade da sua chefia, de entender que tudo é muito rígido, mas que tem horas que é preciso quebrar os protocolos e as regras por algum motivo. Eu acho que ela (a instituição) contribui dando um pouco de liberdade, confiando no profissional. Se a gente está aqui para exercer um cuidado humanizado, isso significa que às vezes se tem que tomar algumas atitudes que, olhando para os protocolos, não vai ser adequado!(Enf. 5)

Os enfermeiros acreditam que o foco nas interações, por ocasião do cuidado, pautado na relação de ajuda e confiança, por reforçar práticas de gentileza e bondade traria contribuições para a instituição considerando o grau de exigência dos pacientes que recebem. As expressões da família podem se tornar, portanto, uma preocupação para os enfermeiros devido às exigências da institução. Os enfermeiros se empenham em realizarem ações de cuidado com a família, que primariamente, lhe tragam segurança e tranquilidade, afastando-os do cuidado que, para tornar-se autêntico, único e transpessoal, necessita considerar o ponto de vista da criança e da família.

Ajuda a atender as necessidades do cliente, que é um cliente exigente e prestar um cuidado seguro e de qualidade. Porque se eu sei me relacionar bem, eu vou ter menos reclamação. Então eu acho que pensando em gestão estratégica (a teoria) vai ter diminuição de reclamações; vai fluir a satisfação do cliente. (Enf. 4)

A experiência dos enfermeiros permitiu ainda que fizessem um comparativo com outras instituições com que têm ou tiveram contato em várias partes do Brasil. Para eles, algumas instutuições não têm a mesma força da filosofia para o cuidado humano, como o hospital do estudo.

Os profissionais sentem-se satisfeitos por terem seu trabalho reconhecido pela instituição e acreditam que essa atitude interfere positivamente na construção de um relacionamento de ajuda e confiança com a família. Embora considerem que essa realidade pode estar presente em qualquer instituição, acreditam que ela é mais evidente, de maneira geral, nas instituições particulares. O principal motivo parece ser a forma 
como as reclamações, expressões dos sentimentos negativos da família repercutem nos profissionais de enfermagem. Nas instituições privadas, onde é possível evidenciar com mais facilidade a negligência do profissional com o cuidado prestado à família, os enfermeiros se preocupam mais com suas atitudes por existirem serviços de avaliação dos clientes, pelas consequencias que podem gerar para o profissional.

Eles (outros hospitais) não têm também uma educação continuada o tempo todo. (...) Há uma desmotivação bem grande dessas equipes porque talvez eles não recebam cuidados da instituição. Acho que isso é o que acontece mais nessas instituições públicas. Não vou falar que na particular não aconteça, mas acho que fica mais gritante nessas. Porque, querendo ou não, às vezes... na particular, tem aquilo que já é a rotina de se fazer, acaba virando uma coisa mecanizada também. Está prescrito! Então: "Eu vou fazer, eu estou prestando assistência senão vão reclamar de mim" O particular tem essa outra vertente. (Enf. 3)

Eu já trabalhei no SUS. Fazer isso lá ia ser assim... nossa! As pessoas já iam falar que não tem funcionário, que não dá para fazer

isso. Já iam por n dificuldades. (...) A cabeça do hospital público é muito mais fechada que a cabeça do particular. Aqui a gente trabalha por qualidade; lá eles trabalham por quantidade! (Enf. 7)

A outra categoria é superando os desafios do relacionamento com

a família. Nela os enfermeiros apontam as dificuldades para desenvolver 0 relacionamento de ajuda e confiança com a família, ao mesmo tempo que as questionam, diante do potencial que a teoria de Watson lhes apresentou para superar todas elas. Para eles, a experiência de se aproximar da teoria ajuda os profissionais a encontrar significados para realizar atividades compatíveis com o que gostam e serem coerentes com os próprios sentimentos. Por isso, muitas das dificuldades podem ser ultrapassadas. Vemos mais uma vez as questões de ordem individual sendo expostas, contra todos os movimentos que buscam padronizar e unificar o cuidado, que não pode ser moldado e restrito a padrões únicos de comportamento, excluindo a individualidade e autenticidade do self nas interações.

Sinceramente eu não acho que seria uma dificuldade. Acho que seria a solução. Penso que se a pessoa, por princípio dela, não achar significado que ela procure ou se perdeu, que consiga resignificar 0 que está fazendo. Ou então também pode chegar à conclusão de que também não é isso que ela queria fazer! (Enf. 12) 
Para os enfermeiros, a ciência do cuidado e suas bases filosóficas possuem um valor pouco considerado, devido à centralização crescente da visão biomédica, dentro do sistema hospitalar. Dessa forma, questões relacionadas às emoções e às interações com famílias, por exemplo, são subvalorizadas pelos próprios colegas de profissão e por uma visão social estigmatizada. Ter uma base e um referencial para o cuidado, como a teoria de Watson, por exemplo, é percebida pelo enfermeiro como um respaldo para que ele possa valorizar mais suas atitudes voltadas para o cuidado.

(A teoria) Trata muito com dessa questão de baixa estima do enfermeiro, porque é a essência do cuidado da enfermagem (...) As pessoas levam essa preocupação com o cuidado pelo lado pejorativo, para o menos poder. As pessoas menosprezam algumas coisas de cuidado, acreditando que isso é menos importante. Não valoriza! Eu to falando do enfermeiro. Na vivência que eu tenho, hoje de 22 anos dentro de um hospital, o enfermeiro acha bonito o que o médico faz e ele não se encontra. Acho que isso (a teoria) traz uma valorização para o profissional. (Enf. 4)

(...) A teoria trata muito de emoções que não são concretas, não parece muito sério. Não tem valor nenhum você falar que você gosta do que você faz, que tem de entender as emoções que estão ocorrendo com a família para tentar prestar um bom cuidado. Quando você se fala de emoções, de amor, de carinho, de raiva parece que

não se tem uma coisa muito científica. Com o referencial, você se sente mais segura, respaldada, porque existe alguma coisa baseada em algo científico. (Enf. 11)

Os fatores que podem contribuir de forma negativa para construir 0 relacionamento de ajuda e confiança do enfermeiro com a família, segundo esse profissional, envolvem a automatização do trabalho em enfermagem, motivação profissional e características sócioafetivas e culturais. Não reconhecer os sentimentos que cercam essas dificuldades, inibem 0 enfermeiro para caminhar profundamente nas inquietações do self e compreender esses conflitos, fazendo com que tais dificuldades se cristalizem e não proporcionem avanços para pensar a relação de ajuda e confiança no cuidado. As habilidades para manejar as tensões produzidas por essas situações são pouco trabalhadas pela equipe de enfermagem interna e externamente e, por isso, os enfermeiros desconhecem os mecanismos para lidar com as eventuais consequências desses fatores. 
A automatização do trabalho de enfermagem retrata o foco e a predominância da preocupação com questões técnicas e das tarefas a serem cumpridas. Sobrecarga de trabalho, acúmulo de empregos, excesso de demanda de tarefas são exemplos de situações que os profissionais entendem interferir na qualidade do cuidado e na formação de um sistema humanístico, gerando sentimentos negativos em relação ao exercício da profissão. Essas condições produzem de fato consequências no cuidado, pois alteram os comportamentos dos enfermeiros, especialmente da ótica que envolve as questões sociais das relações de trabalho. Considerando as formas de cuidado dos indivíduos no espaço restrito das interações, existem fatores mais influentes como a motivação, o comprometimento, os modos de se comunicar que interferem na construção dos vínculos de ajuda e confiança do profissional com a família.

A gente é muito cheia de protocolos, de coisas que sobrecarregam. Acho que nem é o profissional o culpado, mas talvez o modo como são impostas as formas de trabalhar para a gente. Então você acaba se automatizando e isso não é bom. Eu acho que isso faz perder um pouco do que é a essência da profissão, que é o cuidar. (Enf. 5)

Diante disso, os enfermeiros consideraram o tempo, as demasiadas tarefas e preocupações que cercam o ambiente de trabalho motivos que dificultaram uma melhor aproximação dos conceitos teóricos discutidos nos relacionamentos com a família e, portanto, tais restrições constituiriam também dificuldades para trabalhar um referencial com a equipe de enfermagem.

Eu não poderia dizer para você que, depois do workshop, eu mudei as minhas práticas... Não mudei! Mesmo porque a gente teve um estresse de avaliação e teve umas internações aí que foram bem estressantes, assim de relacionamento com a família mesmo. (Enf. 6)

Quando vocês disseram que era para gente dar um feedback (...) Não vou falar que em $100 \%$ das vezes a gente pensou e voltou. Claro que não! Porque se tá naquele "vuco-vuco" e não se consegue.

(Enf. 11)

A dificuldade é que eu praticamente não tive tempo para ler e buscar mais. Mas, por mim a dificuldade que eu tive, sou eu mesma. 
O meu tempo! Eu poderia ter lido mais, eu poderia ter buscado mais. Isso falta em mim! (Enf. 8)

Apesar disso, essa falta de tempo é questionada por alguns enfermeiros que acreditam que o referencial da Watson pode ser utilizado de forma muito simples na construção de um relacionamento. A questão do tempo para os profissionais é empregado como um argumento para atenuar as responsabilidades pessoais em prover mais atenção à família e à criança. Para eles, é possível atender a família, apesar das restrições do tempo, porque as interações fazem parte da consciência da presença do self do enfermeiro, que evidenciam os valores humanos nas relações de cuidado. Um relacionamento congruente é aquele que pressupõe a abertura incondicional ao outro, com sinceridade, genuinidade e transparência, o que permite esclarecerem as limitações que se fizerem presentes tanto da parte do enfermeiro, quanto da parte dos familiares. Adicionando ainda os valores que permitem expressar a gentileza, a bondade e o carinho, vemos que a qualidade do tempo das interações, sobrepõe às restrições que diminuem qualquer oportunidade para que o contato seja de fato exercido.

Claro que não podemos ficar o dia todo conversando mas quando ficar, fazer diferença. Ouvir! Na triagem, olhar nos olhos e se colocar no lugar. (Enf. 2)

(A teoria) Fez um sentido de uma coisa muito simples. Achei que são palavras fáceis, por isso eu acho que ela é fácil de ser assimilada na prática. Porque às vezes a teoria é muito distante da prática, talvez com conceitos, uma filosofia muito profunda. Falar de

Nietzschie no dia a dia da UTI é muito profundo e talvez você não tenha tempo pra isso. Talvez não seja viável falar de Nietszchie atendendo uma parada na UTI. E assim eu penso que dá até para atender uma parada, fundamentada na Watson, porque a coisa é de uma essência muito do humano assim, muito de qualquer um de nós.

(Enf. 4)

Outra dificuldade no desenvolvimento de um relacionamento de ajuda e confiança é a falta de motivação e empenho para essa prática com famílias. Por isso, certo grau de descompromisso com a profissão, desinteresse em ajudar efetivamente o outro e deixar de ser reconhecido, por exemplo, influenciam nos comportamentos dos profissionais para prestar um cuidado humano. 
Digamos assim eu não acreditar naquilo, não estar comprometida. Eu posso ter conhecimento e estrutura, mas se eu não quiser, eu não faço. Tem que querer, acreditar, gostar, estar ali por inteiro. (Enf. 4)

Tem aqueles que falam: 'ah eu não vou fazer porque não vou ganhar nada com isso'. Então a gente vê bastante essa desmotivação nessas equipes. (Enf. 3)

$\mathrm{Na}$ visão da gerência, na enfermagem, ainda encontramos profissionais que não têm dimensão das próprias funções enquanto cuidadores, sendo esta uma grande barreira para administrar as relações que se fazem presentes pela ocasião do cuidado e evidenciar os sentimentos que envolvem esse encontro para promover a conexão do enfermeiro com a família.

Eu confesso que acho que o enfermeiro não sabe bem qual é a bandeira dele (...) Muita gente não sabe, não tem a menor idéia do que está fazendo naquele lugar como enfermeiro. É difícil eu falar, posso estar sendo pretensiosa, preconceituosa, mas às vezes eu olho e falo: 'Meu Deus do Céu, o que será que aquela pessoa entende como enfermagem? Como ser enfermeiro?' Então eu acho que ter essa teoria, ajudaria criar uma bandeira. (Enf. 4)

Apesar das dificuldades mencionadas anteriormente, existem também fatores internos que interferem no relacionamento de ajuda e confiança, relacionados às características sócioafetivas e culturais de cada um. Para os enfermeiros, existem algumas barreiras pessoais que influenciam na construção de um relacionamento mais próximo, não apenas em relação às interações de cuidado, mas também referente à comunidade no geral.

Eu acho que passa por algumas questões de ordem individual mesmo. O quanto que eu vou me expor, o quanto eu dou conta de fazer isso (...) têm diversos tipos de profissional mesmo. (Enf. 4)

Tenho grande dificuldade em ter aquele contato mais próximo com a família (...). Eu acho que é da minha personalidade. Eu sempre fui mais fechada, tenho dificuldade de relacionamento, fazer amizades(...) Tem pessoas que são bem extrovertidas! (Enf. 6)

Converso com a família, mas não sou aquela coisa de ficar floreando. Não sou! Não tenho dificuldade com o trabalho humanizado. Minha dificuldade de relacionamento inicial. Eu falei: "deixa eu ver como é que eu consigo mudar um pouco meu jeito de ser com essa teoria! (Enf. 6) 
Sou muito mais técnica assim. Como eu sou japonesa, acho que eu tenho uma dificuldade maior de falar assim. Tento melhorar essa comunicação entre as pessoas. (Enf. 9)

Outra dificuldade apresentada pelos enfermeiros refere-se ao fato de as ações de cuidado, principalmente aquelas referentes ao relacionamento praticado com gentileza, bondade e comunicação, serem de difícil controle para realizar avaliações que permitam visualizar problemas no processo de cuidado, garantindo constantes melhorias na assistência prestada à família e à criança. Para os enfermeiros, faltam instrumentos que os ajudem a direcionar suas ações para obter melhor controle das suas práticas.

Falta um pouco para colocar na prática, fazer anotação de enfermagem. Fazer prescrição, a escrita, a documentação. Tudo que a gente faz, nada daquilo está registrado. Então você não fez! (Enf. 2)

Porque a gente não sabe mensurar isso. (...) Se melhorou a estrutura física... isso é palpável, visível. Mas o cuidado e o relacionamento equipe-paciente... Isso a gente ainda não consegue mensurar. É uma dificuldade ter algum instrumento palpável, em português para tentar mensurar isso! (Enf. 3) 


\section{DISCUSSÃO}

Este estudo procurou compreender a experiência dos enfermeiros sobre o desenvolvimento da relação de ajuda e confiança com famílias de crianças em unidades de pediatria, à luz da Teoria do Cuidado Humano de Jean Watson. A análise das entrevistas permitiu conhecer melhor a realidade dos enfermeiros, a partir dos significados atribuídos as experiências nos relacionamentos com as famílias, bem como ao referencial teórico do estudo.

Percebemos então que a metodologia qualitativa descritiva (Sandelowski, 2010) contribuiu para explorar essas realidades e foi adequada para interpretar as experiências a respeito do processo de cuidado do enfermeiro para engajar-se em um relacionamento com a criança e a família, bem como os desafios enfrentados em sua prática e os fatores que influenciam essa relação.

A dimensão subjetiva e integral do cuidado nos permite desvelar com maior clareza os fatores que influenciam esse processo, a partir das características pessoais dos sujeitos envolvidos - que, para este estudo, foram considerados os enfermeiros - nas questões do cuidado ao paciente. Assim, estamos de acordo com a visão de cuidado como objeto central de processos interativos e, portanto, inerente aos valores humanos (Waldow, Borges, 2011; Deslandes, 2004; Simões et al., 2007; Ayres, 2005; Oliveira, Zampieri, Brüggemann, 2001; Watson, 2008)

Dessa forma, pensar no desenvolvimento da relação de ajuda e confiança entre enfermeiros e famílias permitiu aprofundar as reflexões acerca do cuidado e da interação com sentimentos, valores e crenças dos seres humanos. Assim, as concepções de Watson (2008) sobre o amor, bondade, gentileza, compaixão, equanimidade, entre outros, no cuidado são relevantes para estabelecer relacionamentos entre enfermeiros e famílias, pela natureza intrínseca e dinâmica desses sentimentos no comportamento humano, a partir do encontro de experiências subjetivas pela ocasião do cuidado (Watson, 2008). O que Watson (2008) propõe é a aproximação desses valores na prática e na consciência de cuidado dos enfermeiros. 
Essa aproximação dos valores e sentimentos nas relações de cuidado em saúde é uma forma de prover um cuidado consciente e, para os enfermeiros, esses valores devem permear não apenas a relação com a criança e com a família, mas também com a equipe de saúde, em geral. Duffy (2003), argumentando sobre a implementação de um modelo de qualidade no cuidado, criado pela mesma autora, diz que os valores, as crenças e os comportamentos dominam o processo de cuidado e são as bases para constituir o principal fundamento para as relações em saúde. Esse relacionamento envolve aquele entre o enfermeiro e o paciente, e também os colaborativos, que incluem ações e responsabilidades que podem ser dividas com a equipe de saúde.

Os enfermeiros deste estudo também identificam que esses relacionamentos podem ser prejudicados por diferentes fatores. Começando pela relação com a equipe, relatam a ausência de algum movimento que permita troca de experiências e um trabalho colaborativo efetivo. Um estudo de revisão bibliográfica (Abreu et al., 2005) sobre o trabalho de enfermagem em equipe evidenciou dificuldades dos enfermeiros no relacionamento entre si, prejudicando a realização de uma abordagem de cuidado integral para os pacientes e famílias.

A comunicação foi uma das estratégias que mais frequentemente apareceu como eixo central para a interação entre a equipe, tanto podendo contribuir quanto prejudicar pelo desconhecimento das estratégias que permitem esclarecer as perspectivas do outro, seja a família seja o colega de equipe e ao mesmo tempo aceitar essas diferenças.

Os enfermeiros valorizam a comunicação devido a sua influência decisiva em vários aspectos do estabelecimento da relação de ajuda e confiança no cuidado. As bases para o 'relacionamento centrado no cuidado', criado pelo grupo Pew Fetzer Task em 1994, consideram a necessidade de adquirir conhecimentos e desenvolver habilidades relacionados a quatro principais áreas: autoconsciência e crescimento pessoal continuado; experiências dos pacientes sobre a saúde e a doença; desenvolvimento e sustentação de relacionamentos com os pacientes e comunicação clara e eficiente (Tresolini, Pew-Fetzer Task Force, 1994). 
Para promover essa comunicação com o paciente ou com outros membros da equipe, é necessário desenvolver habilidades e reforçar os valores necessários para facilitar a execução de atitudes aparentemente simples, mas que são pouco realizadas pelos profissionais de saúde, como ouvir, expressar a aceitação dos sentimentos dos pacientes, oferecer informação, aprender e facilitar o aprendizado de outros. Para isso, é fundamental estar aberto às experiências de cuidado e não julgar as atitudes do outro (Tresolini, Pew-Fetzer Task Force, 1994; Watson, 2008).

Todos esses elementos são identificados nos discursos dos enfermeiros, que reconhecem a importância de cada um deles para estabelecer um relacionamento de ajuda e confiança com as famílias e as crianças, porém não relatam muitas ações pessoais para efetivá-los em seu cotidiano. Esses dados são condizentes com os encontrados no estudo de Lima et al. (2010), que identificou comportamentos dos enfermeiros que não são compatíveis com as necessidades das famílias, principalmente pelo fato de a comunicação se concretizar predominantemente de forma vertical e formal, centrado na perspectiva do profissional e não na da família. Assim, nosso trabalho aponta para o conhecimento teórico que predispõe ao estabelecimento de ajuda e confiança, mas identifica poucas ações dos enfermeiros para iniciar esse processo de relacionamento.

A comunicação interpessoal envolve diversas estratégias para reconhecer e utilizar com consciência as formas verbais e não verbais de expressão no relacionamento entre pessoas e no cuidado delas (Silva, 2002, 2008). Adicionalmente, para a consciência caritas (Watson, 2008), um ingrediente fundamental é a ação genuína e autêntica nos processos de cuidado. Nesse sentido, estar atento às dimensões da comunicação ajuda a resgatar o melhor de uma pessoa para a outra, expressando de forma transparente as percepções e necessidades dos indivíduos envolvidos na interação (Watson, 2008). Os enfermeiros ainda não reconhecem a importância de se colocarem genuinamente como pessoas, também expressando seus próprios pensamentos, sentimentos para que a interação realmente aconteça de forma transparente e aberta (Watson, 1979). 
A comunicação é uma forma de promover tanto o desenvolvimento da relação de ajuda e confiança quanto ajudar os enfermeiros a iniciarem as interações com a família (Watson, 2008; Tresolini, Pew-Fetzer Task Force, 1994). Ao refletirem sobre as ações que os levam a prestar um cuidado autêntico e pautado em valores humanos, estratégias verbais e não-verbais são mencionadas como formas de expressar sentimentos (Gallagher-Lepak, Kubsch, 2009). Essas emoções expressas pelo contato visual ou por meio de qualquer outra prática intencional, como do toque, ajudam os enfermeiros a 'quebrar' as barreiras do engajamento das relações com o paciente e com a família (Gallagher-Lepak, Kubsch, 2009; Pai, Lautert, 2005).

Mas vale ainda ressaltar que, neste estudo, quando a família inicia o relacionamento ou apresenta sinais que permitam aproximação com o profissional, o enfermeiro se sente mais seguro e confortável para se engajar no relacionamento de ajuda e confiança. O silêncio dos familiares pode ser compreendido como um desejo de não - envolvimento e resultar em uma dificuldade do profissional em romper o silêncio, percebido por ele como barreira para encetar o relacionamento com a família. Essas barreiras são as principais causas que afastam o enfermeiro do cuidado da família, principalmente quando ocorrem nos momentos iniciais do encontro (Silva, 2010; Moules et al., 2010).

Por isso, estratégias para ajudar o enfermeiro a começar essa interação são essenciais, visto que estudos mostram que o profissional já está sensibilizado para o trabalho com a família (Wernet, Angelo, 2003). Além disso, outro estudo como de Tapp (1995) mostra que existe um desejo dos enfermeiros em conhecer mais sobre as propostas de intervenção com as famílias, como forma de prover uma interação efetiva, que ajude a compreender a repercussão da doença para cada um dos seus integrantes. No entanto, isso só será possível quando os enfermeiros superarem seus receios de iniciar e se abrir para um relacionamento autêntico e transparente com os familiares do paciente.

É necessário reconhecer as dificuldades que influenciam a construção de um relacionamento com a família para procurar desenvolver habilidades que possam superá-las. $O$ enfermeiro identifica um grande potencial do 
referencial teórico de Watson como suporte para o engajamento nesse processo. Sobre as características individuais e culturais referidas pelos enfermeiros, como restritivas para a relação, Watson (2008) relata que dificuldades inerentes à personalidade podem ser trabalhadas a partir do momento que o enfermeiro percebe os obstáculos pessoais como um impedimento para tornar o encontro com o outro mais centrado em práticas autênticas, criativas, focalizadas no relacionamento de ajuda e confiança no momento de cuidado. Nesse sentido, o material de apoio oferecido na etapa 1 da coleta dos dados estimulou alguns dos enfermeiros a refletir de maneira crítica sobre suas possibilidades no engajamento com a família.

Agir intencionalmente ajuda o enfermeiro a começar essas transformações pelos mecanismos internos que enaltecem as habilidades e capacidades dos indivíduos para darem novas formas às suas práticas, partindo da consciência de seus reais propósitos nas relações para cuidar do outro (Watson, 2002, 2008). Quando alguém intenciona praticar alguma ação, é possível dissipar qualquer resistência e transformá-la intuitivamente. Dessa forma, as intenções não têm objetivos específicos e determinados, mas envolvem um sentido de cooperação que permite promover mudanças a partir de uma referência comum entre o enfermeiro e aquele com quem ele quer desenvolver um relacionamento (Watson, 2002; Pilkington, 2005).

Nesse sentido, os profissionais da enfermagem mostram sensibilidade para o cuidado da família, mas não têm a intenção genuína para exercer práticas criativas e terapêuticas a fim de assegurar que as necessidades dos familiares sejam atendidas. Eles não têm consciência da maneira como essas barreiras podem influenciar na relação com a família e expressam justificativas artificiais para o afastamento, tais como ter que se ocupar de tarefas ou atividades que consideram prioridades no cuidado.

Outro aspecto que os distancia da família são as situações de sofrimento que repercutem da mesma forma neles. Essas situações tornam o ambiente mais propício ao julgamento pelas atitudes das famílias. Nossos dados vão ao encontro dos achados da literatura ao afirmarem que um sentimento de incompetência e falta de adequação no relacionamento com a família sejam fatores que promovam o distanciamento entre enfermeiros e 
familiares para manter o foco no cuidado técnico, área que dominam com mais tranquilidade (Chesla, 1996; Chesla, Stannard, 1997; Hupcey, 1998). Nesse sentido, a prática da enfermagem com a família tem sido vista com maior dificuldade em determinados ambientes, como o de uma UTI, onde a demanda e complexidade tecnológica são priorizadas quando comparadas às interações com a família.

A sensação de domínio do ambiente e da segurança pelo manejo das técnicas são fatores que revelam a natureza estressante das interações entre enfermeiros e famílias, além das dificuldades em lidar com eventos que possam repercutir no domínio de sua prática. (Engstrom, Soderberg, 2007; Hupcey, 1998; Stayt, 2007). Estudos ainda mostram a presença de atitudes inconscientes dos próprios enfermeiros para impedir o desenvolvimento da relação com as famílias (Hupcey, 1998), acreditando que a família interfere nos trabalhos voltados para os pacientes (Soderstrom, Benzein, Saveman, 2003). O conhecimento tecnológico e o ambiente repleto de recursos trazem segurança ao profissional, porém a presença de familiares os coloca em um contexto de insegurança que dificulta a relação com a família.

Os enfermeiros revelaram que a falta de tempo, falta de espaço confortável para os acompanhantes, a sensação de desconfiança em seu trabalho e características sócioafetivas provocam sentimentos de desconforto na interação com as famílias, o que resulta nas dificuldades de engajamento. Outros estudos também relacionam esses fatores para a falta de interação dos enfermeiros com as famílias (Astedt-Kurki et al., 2001, Chesla, 1996; Chesla, Stannard, 1997; Hupcey, 1998; Marco et al., 2006; Soderstrom, Benzein, Saveman, 2003).

Outro motivo relatado pelos enfermeiros para o distanciamento das famílias é a dificuldade em lidar com o sofrimento delas e a repercussão desse sofrimento no próprio profissional. Esses fatores também foram encontrados no estudo de Chesla e Stannard (1997), que argumentam ser essa prática responsável por rotular o fracasso das atitudes de enfermagem voltadas para a família e ainda causam um duplo sofrimento para as famílias que vivenciam uma situação crítica de doença (Arman, Renhsfeldt, 2003). 
Dessa forma, a literatura ressalta a importância de os enfermeiros encontrarem estratégias para iniciar o relacionamento no cuidado para auxiliar a família e não valorizar seu próprio conforto (Lima et al., 2010). Estratégias citadas pelos enfermeiros para ajudar as relações com a criança e com a família, como dar o direito a esta de gerir o banho e utilizar brinquedos terapêuticos são formas fáceis para auxiliar na construção de um relacionamento de ajuda e confiança. No entanto, o enfermeiro deve se fazer presente para firmar vínculos e conquistar a confiança da família, tendo o objetivo terapêutico de amenizar o seu sofrimento, em vez de tê-la como mediadora da relação com a criança, para facilitar o próprio trabalho, provendo-Ihe conforto e segurança (Lima et al., 2010; Guareschi, Martins, 1997). Parece-nos que este é o maior desafio para que o cuidado centrado na família ocorra de fato.

Os fatores relacionados à sobrecarga e demanda de tarefas que, segundo os enfermeiros, favorecem a execução de um trabalho nãoindividualizado e não-integrado, também foram questionados pelos próprios profissionais quando consideravam a perspectiva da teoria e dos elementos que ela pode acrescentar à prática e ao momento de cuidado. Para Watson (2008), um enfermeiro proporciona um cuidado com gentileza, empatia, compaixão e equanimidade, utilizando os caritas process. Dessa forma, as rotinas e tarefas, assim como o cuidado convencional técnico, tornam- se mais integrados e individualizados quando pautado nesses processos. É o senso de humanidade envolvido nas relações de cuidado que permitem ao enfermeiro ir além das tarefas (Lukose, 2011).

Griffiths (2008) argumenta que unir o conhecimento biomédico às perspectivas filosóficas de valores e emoções dos seres humanos para a assistência em saúde será um contínuo desafio para o cuidado em saúde, pela complexidade das interações humanas. $O$ cuidado é um desafio quando se busca aliar a atenção ao sofrimento humano e as manifestações sociais com todo o sistema tecnológico que o envolve. Corbin (2008) sustenta que a enfermagem frequentemente falha nesse desafio de enfrentar as dificuldades para unir as competências das capacidades técnicas ao 
interesse e compromisso com os pacientes e familiares. Reconhece, portanto, vulnerabilidades desse processo.

Os enfermeiros, ao falarem da teoria, principalmente no que diz respeito ao relacionamento de ajuda e confiança, acreditam que, para compatibilizar esses elementos com a prática, é necessária a construção de uma cultura de cuidado no ambiente, para que os profissionais sejam não só influenciados por ela, mas também façam parte da sua construção e reconstrução. A partir do entendimento de que cultura é uma forma de caracterizar um meio social pelos padrões de comportamentos, atitudes e sistemas de idéias (Michaellis, 2008), podemos afirmar que as interações, no momento de cuidado, sejam elas entre família/paciente/enfermeiro sejam entre a própria equipe de enfermagem, constituem uma forma de descrever a cultura de cuidado em um determinado ambiente.

Rytterstro, Cedersund e Arman (2009) acreditam que uma cultura de cuidado forma uma estrutura complexa, que depende da maneira como o cuidado é interpretado e interpretado pelos indivíduos que a praticam, bem como pelas instituições responsáveis por ele. Dessa perspectiva, parte a compreensão de que o cuidado deriva das expressões individuais tanto quanto da cultura, que pode ajudá-lo a atribuir, com o tempo, um significado mais preciso ao cuidado e, dessa forma, exercer influência sobre as mudanças individuais.

Considerando esses dados, para as instituições, como forma e expressão de uma cultura, autores compreendem que os padrões que permitem caracterizar um comportamento partem dos significados atribuídos pelas pessoas às interações com os outros no ambiente de saúde e, portanto, em um contexto onde podem se formar valores, construir idéias e significados (Rytterstro, Cedersund, Arman, 2009; Watson, 2008; Deslandes, 2004) Assim, para pensar em uma cultura organizacional em que 0 relacionamento de ajuda e confiança possa realmente acontecer como forma de cuidado é preciso, a princípio, que os enfermeiros reconheçam os significados, valores, idéias e intenções nas interações entre eles e os envolvidos na ocasião do cuidado. 
Considerando o cuidado e a qualidade das interações como fundamentais para satisfazer enfermeiros e pacientes (Amendolair, 2012; Dodek et al., 2012), trabalhar para favorecer uma cultura de cuidado passa por focalizar questões pessoais e de relacionamento com os outros, para prover um cuidado pautado em valores essenciais e fundamentalmente humanos, permitindo, assim, um encontro com gentileza, bondade, empatia, envolvido por uma comunicação eficaz em um ambiente terapêutico (Watson, Foster, 2003; Mendyka, 2000; Watson, 2010). Partindo de um movimento interno para prover uma cultura de cuidado, entendemos que toda e qualquer forma de influência de ambiente depende dos padrões de comportamentos pessoais e das capacidades para manejar as transformações e inconstâncias do self.

Segundo Watson (2008), não podemos nos envolver na experiência do outro e sustentar a prática caritas sem estarmos pessoalmente preparados. Ainda apresenta uma crítica à maneira como a educação em enfermagem e a sua prática requerem tantos conhecimentos e habilidades para executar o trabalho, mas exigem poucos esforços são direcionados para as formas de ser e agir nas diferentes situações que envolvem o trabalho de enfermagem (Watson, 2010, 2008). Se verdadeiras transformações não se voltarem para as dimensões interiores, corremos o risco de institucionalizar as relações de cuidado com protocolos e instrumentos, mas de não promover um cuidado à beira do leito efetivo (Watson, 2008).

Podemos nos pautar pelas observações expostas por Nelms e Eggenberger (2010) segundo as quais, apesar de algumas unidades terem implementado modelos de cuidado voltados para a família, muitos enfermeiros não identificaram ou não exerceram mudanças significativas em suas práticas ou em suas crenças sobre as experiências da família quando enfrentam uma situação de doença e sofrimento. Sendo assim, a cultura pode influenciar os padrões e comportamentos, mas não pode ser vista como único determinante para desenvolver uma interação de cuidado consciente, genuína e intencional, como propõe a Teoria do Cuidado 
Humano de Jean Watson (2008) e como, da mesma forma, acreditam os enfermeiros participantes deste estudo.

Os aspectos expostos pelos enfermeiros permitem uma reflexão consistente sobre o relacionamento deles com a família, trazendo elementos teóricos do relacionamento de ajuda e confiança, embora não tenham consciência deles em termos conceituais. Atribuímos a identificação dos enfermeiros com o referencial teórico proposto à compatibilidade entre os valores próprios e aqueles necessários para as interações humanas dos profissionais enfatizados pela teoria. O cuidado ressalta essa necessidade e resgata esses valores para a enfermagem, para se constituir como uma disciplina. Certamente tais fatores são fundamentais em todas as profissões, mas se fazem imprescindíveis naquelas em que é necessário desenvolver um relacionamento com o outro (Watson, 2008).

Dessa forma, concordamos que os enfermeiros estejam conscientes da necessidade de trabalhar com famílias (Bousso, 2006; Wernet, Angelo, 2003) e, consequentemente, de procurar estratégias para o relacionamento de ajuda e confiança no cuidado. Bousso (2006) acredita que a dificuldade em transformar a consciência e sensibilização em ações esteja na ausência de instrumentos e referenciais teóricos que concretizem esses anseios. Nossos resultados apontam que, além dos referenciais teóricos, é essencial que o contato com a família, no momento de cuidado, seja uma ocasião intencional do enfermeiro na tentativa de estabelecer uma relação única com cada família. Que se faça presente a confiança, a comunicação eficiente, a congruência, a aceitação positiva incondicional (Watson, 1979, 2008; Bousso, 2006). Para isso, investir em estratégias que promovam esse contato e quebre as barreiras pessoais do engajamento e desenvolvimento das relações é tão importante quanto o conhecimento das tecnociências que fundamentam o cuidado técnico-científico do enfermeiro.

Portanto, o cuidado centrado na família também se refere à qualidade do encontro entre duas ou mais pessoas, influenciadas pela plena consciência do momento com sensibilidade e com um autêntico reconhecimento do próprio self e do outro. 
As interações são construídas pelo contato entre pessoas, que é a motivação primária para estabelecer e manter relacionamentos. Assim, sentimentos como raiva, amor, carinho, bondade, tristeza, entre outros provenientes, tanto dos familiares como dos profissionais podem influenciar decisivamente para estabelecer uma relação de ajuda e confiança. Quando conscientes desses sentimentos e da necessidade de expressá-los, os enfermeiros asseguram o respeito pelo espaço do outro, fornecendo a base de qualquer interação de cuidado que verdadeiramente respeite as expectativas da família.

Em nosso estudo, os enfermeiros, ao considerarem o relacionamento de ajuda e confiança para cuidar de famílias das crianças, percebem as significativas contribuições de um respaldo teórico pautado no cuidado humano, capaz de promover tanto essas interações, como benefícios para si mesmo. 


\section{CONSIDERAÇÕES FINAIS}

Este estudo traz contribuições para pensar, à luz da Teoria do Cuidado Humano de Jean Watson, no relacionamento dos enfermeiros com famílias de crianças a fim de estabelecer a relação de ajuda e confiança no cuidado. $O$ foco no encontro entre o enfermeiro e a família, no momento de cuidado, fundamentado por um referencial como o de Watson, conduz à prática de qualidade, com o objetivo de zelar de forma intuitiva, criativa e empática pelas necessidades de cada criança e família.

Esses elementos são pouco aplicados na prática do enfermeiro, e as equipes carecem de consciência e habilidades para lidar com as famílias, especialmente quando precisam desencadear um relacionamento. Dessa forma, a relação entre profissionais e familiares da criança internada pode se tornar frágil, superficial e isenta de intencionalidade para praticar um cuidado no qual sejam asseguradas as necessidades do ponto de vista dos familiares e, em consequencia, os enfermeiros podem se perceber distante da família.

Apesar disso, os profissionais revelaram uma consciência clara sobre a importância de um relacionamento e sobre a relevância de ter o respaldo de um referencial teórico para o cuidado de enfermagem, reconhecendo a pertinência de articular os elementos da teoria de Jean Watson em sua prática com as famílias.

Trabalhar a consciência e a intencionalidade de uma prática genuína, autêntica, centrada nas necessidades da família evoca os valores humanos necessários para o processo de cuidado. Pensar em estratégias ou meios que favoreçam esse agir consciente e intencional é o primeiro passo para promover significativas transformações e ajudar o engajamento de uma relação de ajuda e confiança entre enfermeiros, crianças e famílias.

Acreditamos que este estudo poderia ter sido feito em mais de uma instituição, de preferência, de iniciativa pública para melhor abranger as diversidades das relações entre enfermeiros e famílias. 
São necessários mais estudos que explorem as ações intencionais dos enfermeiros nos diferentes encontros com famílias em situações de doença. Também recomendamos que novos estudos explorem as percepções de familiares sobre o relacionamento de ajuda e confiança, tal como propõe Jean Watson na Teoria do Cuidado Humano.

Por fim, acreditamos que, para direcionar uma prática que objetive promover interações significativas para o cuidado, os enfermeiros e as instituições podem se apropriar das teorias que melhor traduzam seus valores, para guiar as ações no cuidado, com um contínuo envolvimento dos seus profissionais. Nesse sentido, a teoria de Jean Watson mostrou servir como um respaldo para os enfermeiros e contribuir para a reflexão sobre o desenvolvimento e aprimoramento de uma relação de cuidado pautada na ajuda e confiança, sendo esse um importante fator para fortalecer o vínculo desses profissionais com as famílias de crianças. 


\section{REFERÊNCIAS}

Abreu LO, Munari DB, Queiroz ALB, Fernandes CNSO. O trabalho de equipe em enfermagem: revisão sistemática da literatura. Rev. bras. enferm., v. 58, n. 2, p. 203-207, 2005

Amendolair D. Caring behaviors and job satisfaction. J. nurs. adm. 2012;42(1):34-9.

ANCC. American Nurses Credentialing Center. Magnet Recognition Program Application Manual. Silver Spring, Md: American Nurses Credentialing Center; 2005.

Antunes MJM, Egry EY. O programa Saúde da Família e a reconstrução da atenção básica no SUS: A contribuição da enfermagem brasileira. Rev. bras. enferm. 2001;54(1):98-107.

Arman M, Renhsfeldt A. The hidden suffering among breast cancer patients: A qualitative metasynthesis. Qual Health Res. 2003;13(4):510-27.

Astedt-Kurki P, Paavilainen E, Tammentie T, Paunonen-IImonen M. Interaction between family members and health care providers in an acute care setting in Finland. J Fam Nurs. 2001;7(4):371-90.

Ayres JRCM. Cuidado e reconstrução das práticas de Saúde. Interface comun. saúde educ. 2004;8(14):73-92.

Ayres JRCM. Hermenêutica e humanização das práticas de saúde. Ciênc. saúde coletiva. 2005;10(3):549-60.

Barbosa ECV, Rodrigues BMRD. Humanização nas relações com a família: um desafio para a enfermagem em UTI Pediátrica. Acta sci., Health sci. 2004;26(1):205-12.

Beaton DE, Bombardier C, Guillemin F, Ferraz MB. Guidelines for the process of cross-cultural adaptation of self-report measures. Spine. 2000;25(24):3186-91.

Beck CLC, Gonzales RMB, Denardin JM, Trindade LL, Lautert L. A humanização na perspectiva dos trabalhadores de enfermagem. Texto \& contexto enferm.2007;16(3):502-10.

Bernick L. Caring for older adults: practice guided by Watson's caring-healing model. Nurs Sci Q. 2004;17(2):128-34.

Birk LK. The magnetism of theory: resonance to radiance. J Nurs Adm. 2007;37(3):144-9. 
Bodgan R, Biklen S. Investigação qualitativa em educação: uma introdução à teoria e aos métodos. $2^{2}$ ed. Porto: Porto editora: 1994.

Bomar PJ. Promoting health in families: applying family research and theory to nursing practice. $3^{\underline{a}}$ ed. North Carolina: Saunders, Elsevier; 2004.

Bordin TA. O cuidado que influencia o ser em desenvolvimento a enfermagem, a criança e a família na sala de vacinas. Texto \& contexto enferm. 2000;9(2):683-98.

Bousso RS. Um tempo para chorar: a família dando sentido à morte prematura do filho [tese livre-docência]. São Paulo: Universidade de São Paulo; 2006.

Boyatzis R. Transforming qualitative information: thematic analysis and code development. Thousand Oaks: Sage, 1998.

Boykin A. Living a caring-based program. New York (NY): National League for Nursing; 1994.

Brasil. Lei n. 8.069, de 13 de julho de 1990. Dispõe sobre Estatuto da Criança e do Adolescente e dá outras providências [legislação na Internet]. Brasília; 1990 [citado 2012 maio 01]. Disponível em: http://www.planalto.gov.br/ccivil_03/leis/L8069.htm

Brasil. Ministério da Saúde. Diretrizes e normas regulamentadoras de pesquisa envolvendo seres humanos. Resolução 196/96 do Conselho Nacional de Saúde de 10 de outubro de 1996.

BRASIL. Ministério da Saúde. HumanizaSUS: Política Nacional de Humanização: a humanização como eixo norteador das práticas de atenção e gestão em todas as instâncias do SUS / Ministério da Saúde, SecretariaExecutiva, Núcleo Técnico da Política Nacional de Humanização. - Brasília: Ministério da Saúde, 2004.

BRASIL. Ministério da Saúde. Manual do Programa Nacional de Humanização da Assistência Hospitalar. Mimeo. Brasília, 2000.

Burns CM. Assessing staff nurses' styles of involvement with the families of their patients [tese doutorado]. Gainesville (FL): University of Florida; 2002.

Cara C. The Pragmatic View of Jean Watson's Caring Theory. International Journal for Human Caring. 2003;7(3):51-61.

Carraro TE. Sobre teorias e marco conceitual: sua influência na metodologia da assistência. In: Westphalen MEA, Carraro TE, organizadores.

Metodologias para a assistência de enfermagem: teorizações, modelos e subsídios para a prática. Goiânia:AB; 2001. 
Caruso EM, Cisar N, Pipe TB. Creating a healing environment: an innovative educational approach for adopting Jean Watson'sTheory of Human Caring. Nurs Adm Q. 2008;32(2):126-32.

Carvalho MCB. A priorização da família na agenda da política social. In: Kaloustian SM, organizador. Família Brasileira: A base de tudo. Brasília: Cortez; 2000. p. 93-108.

CCEP. Caritas Coach Education Program. Watson Caring Science Institute. Flyer. Out, 2010. Disponível em: http://www.watsoncaringscience.org/cfwebstorefb/files/CCEP\%20 Flyer_Oct2010_Cohort\%206.pdf. Acesso em: 20 de outubro de 2010.

Chesla CA, Stannard D. Breakdown in the nursing care of families in the ICU. Am J Crit Care. 1997;6(1):64-71.

Chesla CA. Reconciling technologic and family care in critical-care nursing. Image J Nurs Sch. 1996;28(3):199-203.

Clarke PN, Watson J, Brewer BB. From theory to practice: caring science according to Watson and Brewer. Nurs Sci Q. 2009;22(4):339-45.

Corbin J. Is caring a lost art in nursing? Int J Nurs Stud. 2008;45(2):329-332.

Costa CA, Lunardi FW, Soares NV. Assistência humanizada. Rev. bras. enferm. 2003; 56(3):310-4.

Crabtree B, Miller W. Doing qualitative research. Newbury Park: Sage, 1999.

Creswell JC. Qualitative inquiry and research design: choosing among five approaches. $2^{\mathrm{a}}$ ed. Thousand Oaks: Sage, 2007.

Deslandes SF. Análise do discurso oficial sobre humanização da assistência hospitalar. Ciênc. saúde coletiva. 2004;9(1):7-13.

Dodek PM, Wong H, Heyland DK, Cook DJ, Rocker GM, Kutsogiannis DJ, et al. The relationship between organizational culture and family satisfaction in critical care. Crit Care Med. 2012;40(5):1506-12.

Duffy JR. The Quality-Caring Model: blending dual paradigms. ANS Adv Nurs Sci. 2003;26(1):77-88.

Elsen I, Althoff CR, Manfrini GC. Saúde da Família: desafios teóricos. Fam Saúde Desenv. 2001; 3(2):89-97.

Engstrom A, Soderberg S. Close relatives in intensive care from the perspective of critical care nurses. J Clin Nurs. 2007;16(9):1651-9.

Erci B, Sayan A, Tortumluoglu G, Kiliç D, Sahin O, Güngörmüş Z. The effectiveness of Watson's Caring Model on the quality of life and blood pressure of patients with hypertension. J Adv Nurs. 2003;41(2):130-9. 
Faquinello P, Higarashi IH, Marcon SS. Atendimento humanizado em unidade pediátrica:percepção do acompanhante da criança hospitalizada. Texto \& contexto enferm. 2007;16(4):609-16.

Favero L, Meier MJ, Lacerda MR, Mazza VA, Kalinowski LC. Aplicação da Teoria do Cuidado Transpessoal de Jean Watson: uma década de produção brasileira. Acta paul. enferm. 2009,22(2):213-8.

Fereday J, Muir-Cochrane E. Demonstrating rigor using thematic analysis: a hybrid approach of inductie and deductive coding and theme development. Int J Qualit Methods. 2006; 5(1):1-11.

Ferreira L, Melo E, Reis G, Mello D. Validation and reliability analysis of the Portuguese language version of Needs of Parents Questionnaire. J. pediatr. (Rio J.). 2010;86(3):221-6.

Fonseca ALN, Lacerda MR, Maftum MA. O cuidado transpessoal de enfermagem no domicílio ao portador de transtorno mental e sua família. Cogitare enferm. 2006;11(1):9-15.

Friedman MM, Bowden VR, Jones VR. E. Family Nursing: Research, theory and practice. . 5 ed. Upper Saddle River, NJ: Prentice Hall. 2003.

Gallagher-Lepak S, Kubsch S. Transpersonal caring: a nursing practice guideline. Holist Nurs Pract. 2009;23(4):171-82.

Gomes GC, Erdmann AL. O cuidado compartilhado entre a família e a enfermagem à criança no hospital: uma perspectiva para a sua humanização. Rev. gaúch. enferm. 2005;26(1):20-30.

Griffiths P.The art of losing ....? A response to the question is caring a lost art? Int J Nurs Stud. 2008;45 (3):329-32.

Guareschi APDF, Martins LMM. Relacionamento multiprofissional, criança e acompanhante: desafio para a equipe. Rev. Esc. Enferm. 1997;31(3):423-36.

Guillemin F, Bombardier C, Beaton DE. Cross-cultural adaptation of healthrelated quality of life measures: literature review and proposed guidelines. $J$ Clin Epidemiol. 1993;46(12):1417-32.

Hupcey JE. Establishing the nurse-family relationship in the intensive care unit. West J Nurs Res. 1998;20(2):180-94.

Institute for Family-Centered Care (IFCC). Partnering with patients and families to design a patient-and family-centered health care system: recommendations and promising practices. 2008. [citado 2011 out 15]. Disponível em:

http://www.familycenteredcare.org/pdf/PartneringwithPatientsand Families.pdf. 
Lacerda MR. O cuidado transpessoal de enfermagem no contexto domiciliar. Cogitare enferm. 1997;2(1):44-9.

Leininger MM. Culture care diversity \& universality: a theory of nursing. New york: National League for Nursing Press, 1991.

Lima AS, Silva VKBA, Collet N, Reichert APS, Oliveira BRG. Relações estabelecidas pelas enfermeiras com a família durante a hospitalização infantil. Texto \& contexto enferm. 2010;19(4):700-8.

Lukose A. Developing a practice model. Nurs Sci Q. 2011;24(1):27-30.

Marco L, Bermejillo I, Garayalde N, Sarrate I, Margall MA, Asiain MS. Intensive care nurses' beliefs and attitudes towards the effect of open visiting on patients, family and nurses. Nurs Crit Care. 2006;11(1):33-41.

Mendyka BE.Exploring culture in nursing: a theory-driven practice. Holist Nurs Pract. 2000;15(1):32-41.

Milne J, Oberle K. Enhancing rigor in qualitative description: a case study. J Wound Ostomy Continence Nurs. 2005;32(6):413-20.

Minayo MCS. O desafio do conhecimento: pesquisa qualitativa em saúde.

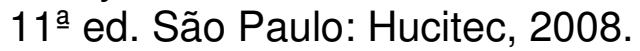

Moderno dicionário da lingual portuguesa[dicionário na Internet]. Editora Melhoramentos: UOL, 2009. [citado 2012 abr 20]. Disponível em http://michaelis.uol.com.br/moderno/portugues/index.php

Moules NJ, Macleod MLP, Thirsk LM, Hanlon N. "And Then You'll See Her in the Grocery Store ": The Working Relationships of Public Health Nurses and High-Priority Families in Northern Canadian Communities. J Pediatr Nurs. 2010;25(5):327-34.

Nascimente KC, Erdmann AL. Cuidado transpessoal de enfermagem a seres humanos em unidade crítica. Rev. enferm. UERJ. 2006;14(3):333-41.

Nelms TP, Eggenberger SK. The Essence of the Family Critical Illness Experience and Nurse-Family Meetings. J Fam Nurs. 2010;16(4):462-86.

Newman M. Health as Expanding Consciousness. Philadelphia: F. A. Davis, 1994.

Nightingale F. Notas sobre enfermagem: o que é e o que não é. São Paulo: Cortez; 1989.

Norman V, Rutledge DN, Lynch AMK, Albeg G. Uncovering and recognizing nurse caring from clinical narratives. Holist Nurs Pract. 2008;22(6):324-35. 
Oliveira ME, Zampieri MFM, Brüggemann OM. A melodia da humanização: reflexões sobre o cuidado no processo de nascimento. Florianópolis: Cidade Futura; 2001.

Orem DE. Nursing: concepts of practice. 2. ed. New York: McGrau-Hill, 1980.

Paganini MC. Humanização da prática pelo cuidado: um marco de referência para a enfermagem em unidades críticas. Cogitare enferm. 2000;5(esp.):7382.

Pai DD, Lautert L. Suporte humanizado no Pronto Socorro: um desafio para a enfermagem. Rev. bras. enferm. 2005;58(2):231-4.

Patton TJF, Barnhart DA, Bennett PM, Porter BD, Sloan RS. Jean Watson: Philosophy and science of caring. In: Tomey AM, Alligood MR. Nursing Theorists and theirs works. London: Mosby, 5 ed, cap 12. 2002;:142-56.

Pauli MC, Bousso RS. Crenças que permeiam a humanização da assistência em unidade de terapia intensiva pediátrica. Rev. latinoam. enferm. 2003;11(3):280-6.

Peduzzi M. Trabalho em equipe de saúde no horizonte normativo da integralidade, do cuidado e da democratização das relações de trabalho. In: Pinheiro RB, Barros ME, Mattos RA. trabalho em equipe sob o eixo da integralidade: valores, saberes e práticas. Rio de Janeiro: CEPESC. 2007.p.161-77.

Persky GJ, Nelson JW, Watson J, Bent K. Creating a profile of a nurse effective in caring. Nurs Adm Q. 2008;32(1):15-20.

Pilkington FB. The concept of intentionality in human science nursing theories. Nurs Sci Q. 2005;18(2):96-8.

Pinto JP, Ribeiro CA, Pettengill MM, Balieiro MMFG. Cuidado centrado na família e sua aplicação na enfermagem pediátrica. Rev. bras. enferm. 2010;63(1):132-5.

Pipe TB. Illuminating the inner leadership journey by engaging intention and mindfulness as guided by caring theory. Nurs Adm Q. 2008;32(2):117-25.

Rafael ARF. Watson's philosophy, science, and theory of human caring as a conceptual framework for guiding community health nursing practice. ANS Adv Nurs Sci. 2000;23(2):34-49.

Rocha SMM, Almeida MCP. O processo de trabalho da enfermagem em saúde coletiva e a interdisciplinaridade. Rev. latinoam. enferm. 2000;8(6):96101.

Roger ME. A theoretical basis of nursing. Philadelphia: F.A. Davis; 1970. 
Roger ME. The Science of Unitary Human Beings: Current Perspectives. Nurs Sci Q. 1994;7(1):33-5.

Rogers CR. Terapia centrada no cliente. Lisboa: Moraes Editores, 1974.

Rosenberg S. Utilizing the language of Jean Watson's caring theory within a computerized clinical documentation system. Comput Inform Nurs. 2006;24(1):53-6.

Royal College of Nursing (RCN). Defending Dignity: opportunities and challenger for nursing. 2008.

Rytterstro P, Cedersund E, Arman M. Care and caring culture as experienced by nurses work ing in different care environments: $A$ phenomenological-hermeneutic study. Int J Nurs Stud. 2009; 46(5):689-98.

Saewyc EM. Nursing Theories of Caring : A Paradigm for Adolescent Nursing Practice. J Holist Nurs. 2000;18(2):114-28.

Sandelowski M. What's in a name? Qualitative description revisited. Res Nurs Health. 2010; 33(1):77-84.

Sessanna L. Teaching holistic child health promotion using Watson's theory of human science and human care. J Pediatr Nurs. 2003;18(1):64-8.

Silva AL, Nascimento AL, Virgílio MS, Mendonça RS. Análise dos fatores de cuidado de Watson em uma unidade de emergência. Rev. gaúch. enferm. 2002;23(2):27-50.

Silva MCLSR. Entrevista de 15 minutos: uma ferramenta para abordagem familiar no PSF. [dissertação]. São Paulo: Escola de Enfermagem, Universidade de São Paulo; 2010.

Silva MJP. Comunicação tem remédio: a comunicação nas relações interpessoais em saúde. 6 ed. São Paulo: Edições Loyola, 2008.

Silva MJP. O papel da comunicação na humanização da atenção à saúde. Bioética. 2002;10(2):73-88.

Simões ALA, Rodrigues FR, Tavares DMS, Rodrigues LR. Humanização na saúde:enfoque na atenção primária. Texto \& contexto enferm. 2007;16(3):439-44.

Soderstrom I, Benzein E, Saveman B. Nurses' experiences of interactions with family members in the intensive care unit. Scand J Caring Sci. 2003 Jun;17(2):185-92.

Souza SM, Lacerda MR. Cuidado transpessoal de enfermagem domiciliar a clientes neoplásicos e suas famílias. Texto \& contexto enferm. 2000;9(2):726-36. 
Sperber AD. Translation and validation of study instruments for crosscultural research. Gastroenterology. 2004 Jan;126(1 Suppl 1): S124-8.

Stamm M. Enfermagem e família em situação de alcoolismo: uma proposta de cuidado. Texto \& contexto enferm. 2000; 9(2):621-31.

Stayt LC. Nurses' experiences of caring for families with relatives in intensive care units. J Adv Nurs. 2007;57(6):623-30.

Tanji S, Novakoski LER. O cuidado humanístico num contexto hospitalar. Texto \& contexto enferm. 2000;9(2):800-11.

Tapp DM. Conserving the vitality of suffering: Addressing family constraints to illness conversation. Nurs Inq. 2001;8(4):254-63.

Tresolini CP, Pew-Fetzer Task Force. Health Professions Education and Relationship-centered Care. San Francisco, CA: Pew Health Professions Commission, 1994.

Waldow VR, Borges RF. Cuidar e humanizar: relações e significados. Acta paul. enferm. 2011;24(3):414-8.

Waldow VR. Atualização do cuidar. Aquichan. 2008;8(1): 85-96.

Waldow VR. Cuidar: expressão humanizadora da enfermagem. Petrópolis (RJ): Vozes, 2006.

Waldow VR. Uma experiência vivida por uma cuidadora, como paciente, utilizando a narrativa literária. Texto \& contexto enferm. 2011;20(4):825-33.

Watson Caring Science Institute. Caritas Coach Education Program (CCEP). Core Concepts of Jean Watson's theory of human caring/caring science. [online] Disponível em: http://www.watsoncaringscience.org/. Acesso em 10 de abril de 2012.

Watson J, Foster R. The Attending Nurse Caring Model: integrating theory, evidence and advanced caring-healing therapeutics for transforming professional practice. J Clin Nurs. 2003;12(3):360-5.

Watson J. Nursing: human science and human care. Norwalk, Connecticut: Appleton - Century - Crofts, 1985.

Watson J. Caring as the essence and science of Nursing and health care. Mundo saúde. 2009;33(2):143-9.

Watson J. Caring Science and the next decade of holistic healing: transforming self and system from inside out. Beginnings. 2010;30(2):14-6.

Watson J. Caring science as sacred science. Philadelphia (USA): FA Davis; 2005. 
Watson J. Intentionality and caring-healing conciousness: a practice of transpersonal nursing. Holist Nurs Pract. 2002;6(4):12-19

Watson J. Nursing. The Philosophy and Science of Caring. Boulder: University Press of Colorado; 1979.

Watson J. Postmodern nursing and beyond. Toronto, Canada: Churchill Livingstone. 1999.

Watson J.. Nursing. The Philosophy and Science of Caring. Boulder: University Press of Colorado; Revised Edition, 2008.

Watson J.. Watson's theory of human caring and subjective living experiences: carative factors/ caritas processes as disciplinary guide to the professional nursing practice. Texto \& contexto enferm. 2007;16(1):129-135.

Watson J.The theory of human caring: Retrospective and prospective. Nurs Sci Q. 1997; 10(1):49-52.

Wernet M.; Angelo M. Mobilizando-se para a família: dando um novo sentido à família e ao cuidar. Rev. Esc. Enferm. USP. 2003;37(1):19-25.

Wright LM, Bell JM. Retorspective - nurses, families and illness: a new combination. J Fam Nurs. 2004;10(3):3-11.

Wright LM, Leahey M. Enfermeiras e famílias: um guia para avaliação e intervenção na família. 4. ed. São Paulo: Roca, 2009.

Wright LM, Watson WL, Bell JM. Beliefs: the heart of healing in family and illness. New York: Basic Books, 1996. 


\section{APÊNDICES}

Apêndice A - Modelo do convite para participação na oficina

\section{Você já parou para pensar...}

Qual o papel do enfermeiro no cuidar?

Como podemos tornar o cuidado mais humano?

A utilização de um referencial teórico pode guiar ações, que respeitem os valores humanos, nas experiências do cuidar. A Teoria do Cuidado Humano de Watson apresenta o cuidado como objeto central da enfermagem. Acreditamos que é possível aproximar esse referencial na prática do cuidado prestado às crianças e famílias que passam por situação de doença.

Oficina - Da teoria para a prática: o cuidado humano e o papel da enfermagem no atendimento das famílias de crianças hospitalizadas.

Local:

Organização: Profa. Dra. Regina Szvlit Bousso, Maiara Rodrigues dos Santos, Escola de Enfermagem da USP. 


\section{Apêndice B - Material de apoio para oficina: Desenvolvendo um relacionamento de ajuda e confiança no cuidado (frente)}

\begin{tabular}{|c|c|c|}
\hline $\begin{array}{l}\text { Carative } \\
\text { Factors } \\
(1979,1985)\end{array}$ & $\begin{array}{l}\text { Caritas } \\
\text { Processes } \\
(2002-2008)\end{array}$ & 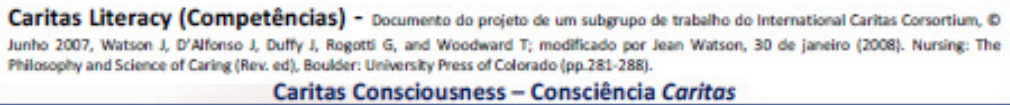 \\
\hline $\begin{array}{l}\text { Desenvolvimento } \\
\text { de um } \\
\text { relacionamento } \\
\text { de ajuda e } \\
\text { confiança } \\
\text { (cuidado } \\
\text { humano) }\end{array}$ & $\begin{array}{l}\text { Desenvolver e } \\
\text { sustentar } \\
\text { relacionamentos } \\
\text { autênticos de } \\
\text { ajuda e } \\
\text { confiança }\end{array}$ & $\begin{array}{l}\text { Eu desenvolvo relacionamentos de cuidado de ajuda e confiança com pacientes (outros), familias } \\
\text { e membros da equipe de saúde. } \\
\text { - Participa da experiência para explorar as possibilidades no momento e no relacionamento. } \\
\text { - Assegura o amor incondicional e o respeito pelo outro. } \\
\text { - Procura trabalhar a partir das perspectivas do outro. } \\
\text { - Assegura um espaço sagrado de recuperação para o outro em seu momento de necessidade. } \\
\text { - Pratica atitudes de não-julgamento. } \\
\text { - Responde ao outro em congruência com as experiências vividas pelo outro. } \\
\text { - Pratica a presença autêntica: } \\
\text { - Está presente de forma total e autêntica no relacionamento com o outro. } \\
\text { - Demonstra sensibilidade e abertura ao outro. } \\
\text { - Pratica um relacionamento pessoa-pessoa e não pessoa-objeto. } \\
\text { não verbal). }\end{array}$ \\
\hline $\begin{array}{r}\text { VOCÁBULOS DE O } \\
\text { USANDO A TEOR } \\
\text { Desenvolver rela } \\
\text { cuidado baseo } \\
\text { confi }\end{array}$ & $\begin{array}{l}\text { UTROS SISTEMAS } \\
\text { IA DE WATSON: } \\
\text { cionamentos de } \\
\text { los em ajudae } \\
\text { ança } \\
\text { cionamentos de } \\
\text { com os pacientes, } \\
\text { equipe. }\end{array}$ & $\begin{array}{l}\text { - Procurar esclarecer dúvidas, quando necessário. } \\
\text { - Promove a comunicação direta, construtiva e respeitosa: } \\
\text { oEmpenha-se numa comunicação que promova uma convivência saudável; não se envolve em } \\
\text { fofoca. } \\
\text { oEmpenha-se em uma comunicação eficiente e afetuosa; não se envolve em boatos. } \\
\text { ompenha-se na solução de problemas de forma pró-ativa; não se envolve em reclamações } \\
\text { excessivas/ crônicas. } \\
\text { ostimula atividades que maximizem a independência e liberdade individual, não a } \\
\text { dependência. } \\
\text { - Empenha-se em atividades que promovam experiências de crescimento que sejam saudáveis, } \\
\text { maduras, éticas e seguras; năo se envolve em comportamentos sedutores, arriscados, ilegais } \\
\text { e não éticos. }\end{array}$ \\
\hline
\end{tabular}

\section{Material de apoio para oficina (verso)}

\section{CONCEITOS DA TEORIA DO CUIDADO HUMANO DE JEAN WATSON}

Abordagem Reflexiva/Meditativa: (aumentando a consciência e presença em relação aos valores humanista de si mesmo e do outro) (Veja Cara, C (2003). A Pragmatic View of Jean Watson's Caring Theory, www.humancarinq.orq (em "educação continuada) (Uma Visão Pragmática da Teoria do Cuidado de Jean Watsan)

Compreendendo a si mesmo por meio de reflexão/meditação (anotação em diário pessoal, artes, meditação, etc.):

- Qual o significado de cuidar de uma pessoa/ famílias ou de si mesmo(a)?

- Como eu expresso o meu cuidado de maneira consciente e comprometida para o meu paciente/cliente? Para os meus colegas de trabalho? Para a instituição? Para a comunidade e ao mundo todo?

- Como eu defino 'self', enfermeiro, pessoa, ambiente, saúde, recuperação e enfermagem?

- Como eu faço a diferença na vida e sofrimento de uma pessoa?

- Como eu melhoro a qualidade do processo de recuperação ou morte de uma pessoa?

- Como posso ser informado (a) pelo Processo "Clinical Caritas" em minha prática profissional?

-Como posso ser inspirado pela teoria de cuidado de Watson em minha prática? 


\section{Apêndice C - Material de apoio para oficina}

O cuidado humano na pratica da enfermagem: pequenas ações, grandes mudanças.
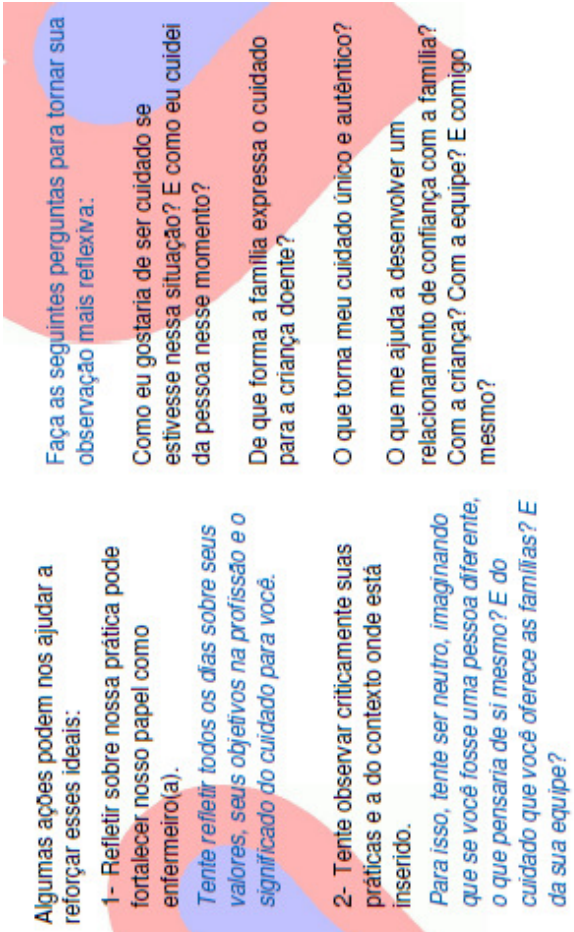
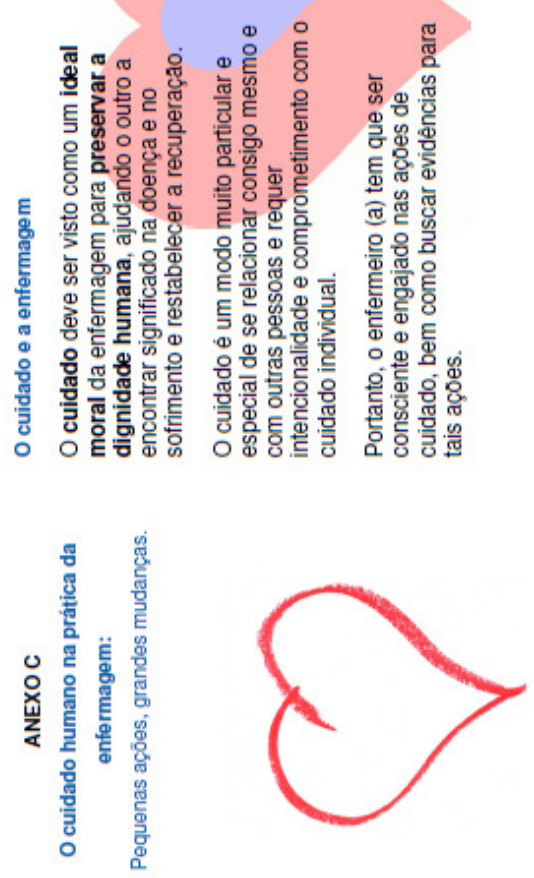
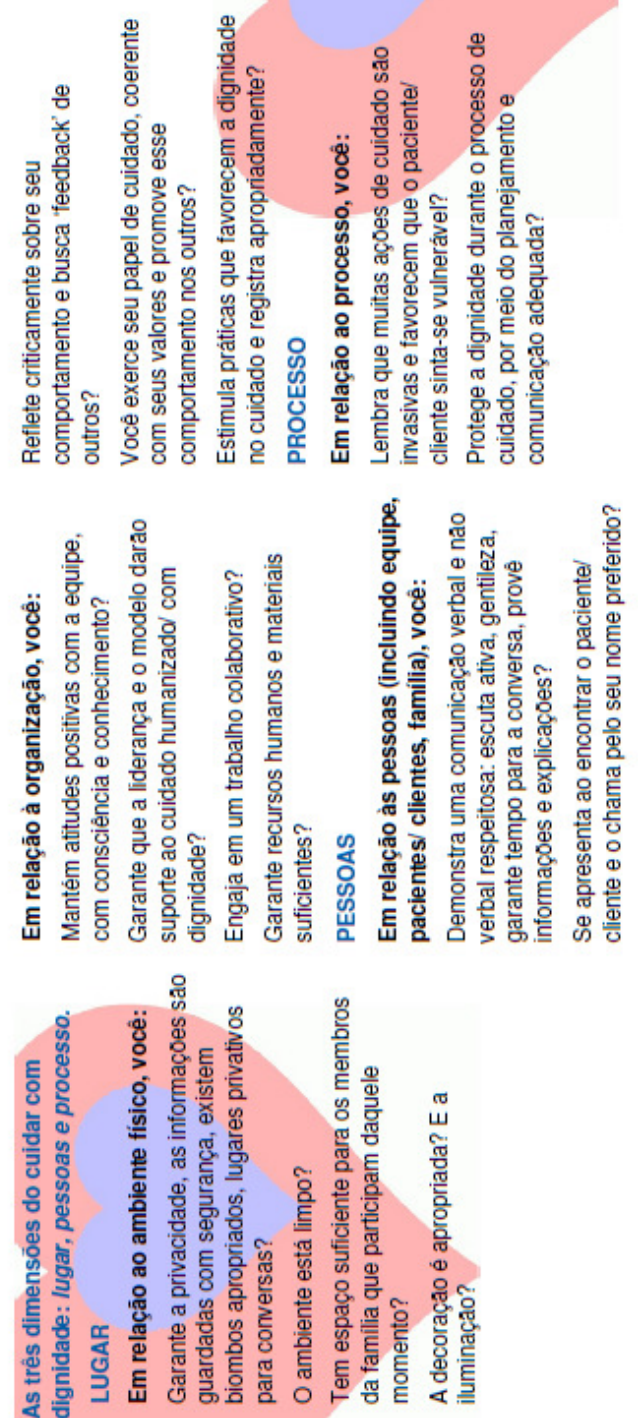


\section{Apêndice D - TERMO DE CONSENTIMENTO LIVRE E ESCLARECIDO PARA PARTICIPAÇÃO NA PESQUISA CIENTÍFICA}

Projeto - A relação de ajuda e confiança entre enfermeiros e familiares de crianças internadas

Essas informações estão sendo fornecidas para sua participação voluntária neste estudo, que visa compreender a experiência dos enfermeiros sobre o desenvolvimento da relação de ajuda e confiança com famílias de crianças em unidades de pediatria, à luz da Teoria do Cuidado Humano de Jean Watson. Acreditamos que, este estudo, pode contribuir no engajamento dos enfermeiros na relação de cuidado da criança e da família. Os enfermeiros que participaram da oficina "Da teoria para a prática: o cuidado humano no atendimento das famílias de crianças hospitalizadas" foram convidados para este estudo e para repensarem suas relações com as famílias, procurando se engajar na prática intencional de um relacionamento de ajuda e confiança. Após um período de 30 a 60 dias, a aluna responsável pela pesquisa, entrará em contato com os participantes da oficina para contribuírem com uma entrevista, visando compartilhar sua experiência.

A entrevista é voluntária e será realizada em local de escolha do enfermeiro, assegurando a privacidade, e seu conteúdo será gravado para posterior transcrição e análise. $\mathrm{O}$ arquivo digital das entrevistas ficará guardado confidencialmente com a aluna. Esclarecemos que a participação poderá ser interrompida em qualquer momento, mesmo após ter sido assinado o termo, sem prejuízo algum. Informamos que os resultados da pesquisa, incluindo os dados coletados somente serão utilizados nesta pesquisa, bem como em trabalhos científicos, apresentação em congressos e revistas da área. Os nomes não serão mencionados e serão mantidos em sigilo. Este estudo oferece nenhum risco para os participantes, bem como nenhum benefício direto.

Em qualquer etapa do estudo, você terá acesso aos profissionais responsáveis pela pesquisa para esclarecimento de eventuais dúvidas. A pesquisadora: Maiara Rodrigues dos Santos pode ser encontrada no endereço Av Enéas de Carvalho Aguiar, № 419 - Cerqueira César - São Paulo - CEP: 05403 000, ou pelo telefone: 1130617601 . Se você tiver alguma consideração ou dúvida sobre a pesquisa, entre em contato com o Comitê de Ética em Pesquisa (CEPEEUSP) - Av Enéas de Carvalho Aguiar, ํo 419 - 2oandar. - Cerqueira César São Paulo. Fone: 3061-7548 - E-mail: edipesq@usp.br 


\section{CONSENTIMENTO PÓS-ESCLARECIDO}

Acredito ter sido suficientemente informado a respeito das informações que li ou que foram lidas para mim, descrevendo o estudo 'A relação de ajuda e confiança entre enfermeiros e familiares de crianças internadas'.

Eu discuti com a aluna Maiara Rodrigues dos Santos sobre a minha decisão em participar nesse estudo. Ficaram claros para mim quais são os propósitos do estudo, os procedimentos a serem realizados, seus desconfortos e riscos, as garantias de confidencialidade e de esclarecimentos permanentes. Ficou claro também que minha participação é isenta de despesas. Assim, concordo voluntariamente em participar deste estudo e poderei retirar o meu consentimento a qualquer momento, antes ou durante o mesmo, sem penalidades, prejuízo ou perda de qualquer benefício que eu possa ter adquirido.

Assinatura do profissional

Data

Maiara Rodrigues dos Santos

Responsável pelo estudo

Data / / 